\title{
Linguagem e pensamento
}

\section{conservador: Aristóteles}

\section{fonte da sociologia}

\author{
Maria Sylvia Carvalho Franco
}

\section{Fustel de Coulanges: Aristóteles à sombra de Luiz Bonaparte}

Operaram-se, no Renascimento, mudanças radicais nas concepçōes de tempo e espaço, sobretudo no interior da critica ao anstotelismo. Assim, a subversăo, poderlamos dizer, dos hames entre todo e partes, que emergiu nas teorias copernicanas, repercutindo em questóes fundamentais como a homogeneização do espaço, a idesia de um centro absoluto, a tese dos movimentos necessariamente regulares e únicos. "Para Aristóteles, o espaço exerce certa ińluência, os lugares năo diferem apenas por sua posiçăo relativa, mas também pela posse de propriedades distintas: o espaço desempenha um papel ativo no movimento das coisas que o percorrem, cada elemento sendo atraldo para seu lugar proprio."(11\}

Cada vez mais, nos tempos modemos, o espaço vivo e animado foi sendo substituido pela extensão inerte, abstrata, suporte das coisas. Em contraste com o tempo - rápido e cruel devorador - a imagem do espaço estável e harmonioso loi assumindo privilégio.

Nas ciências sociais, a reconstituiçâo de pequenos e antigos agrupamentos poderia nos conduzit, mesmo pela via de Marx (talvez por isto mesmo), diretamente a Aristoleles, fortalecendo os componentes espacializados de seu pensamento, reportando-se à sua concepçáo de todo (to holon) ou de composto concreto (tó sýnolon) $)^{(2)}$, referidos ambos, fundamentalmente, à natureza ${ }^{(3)}$. A própria definiçåo de todo, na Metafisica, ao estabelecer sua integridade, enfatiza esse aspecto: nenhuma parte Ihe talta, "a partir do que se chama todo por natureza". Reforçando esse sentido, ele ế dito untário, enunciando-se os seus componentes: constitui melhor um todo aquelas coisas que săo "mais por natureza que por artillcio"(4).

A limitação espacial, a grande insistència na contınuidade das partes firmemente integradas, unificando os elementos históricos, sócio-económicos, psiquicos, ecologicos, religiosos, ımaginá. rios, carreiam para os estudos sociais essa naturalização e consistência interna - longínquo, mas persistente e inexaurivel legado anstotélico.

Nesses trabalhos, o circuito orgânico e solidário é a premissa - por vezes silenciosa, muitas outras esquecida ou mesmo insuspeitada - coerente com as formulações de Aristóteles sobre o lodo, visto como anterior a seus componentes. Dadas as múltiplas vias pelas quais recebemos essa herança, torna-se indispensável rever o texto aristotélico e nele descartar o recorte subja. cente à constituiçăo da sociologia e da antropologia na virada do século XIX para o XX.

Fustel de Coulanges oferece um bom ponto de partida. Em suas páginas, assim como nas de outros helenistas, conligurou-se uma Grécia primacial ariana, onde religiáo, famnlia e proprieda. de surgem como essenciais. Nele, o cientffico e prosaico retorno ao passado tingiu-se com tortes tintas conservadoras no filistino reino de Napoleăo Le Petit. O conferencista da imperatriz aplicouse em dissipar, por completo, as ilusỏes de uma origem francesa politicamente igualitária, sern propriedade privada e carente de sua garantia infalivel, a famia. Os lundamentos religiosos também năo foram negligenciados. Medievalista, escrutinou as fontes, delas inferindo um passado garantidor de idêntico futuro, aninhando uma sociologia capaz de legitimar empiricarnente o ideário burguès lace ao evolucionismo romántico ou de esquerda, que deduzia o passado como negaçăo do presente e como espelho - mas não retorno - dos tempos a vir.
MARIA SYLVIA CARVALHO FRANCO É prolessora do Departamento de Filosotia da FFL.CH.USP. na selor de Filosofia Polnica e Teona das Ciéncias Humanas, e autora de Homens livres na ordem escravocrata (Kauros Editora).

\footnotetext{
1 La structure postique du mondo: Ca pernic, Kepler, F. Hallyn. Paris, Souil. 1087. p. 21.

2 Molatisica, 1023D $27-1024$ b 11. TIt cot traduz is synaion por "compose concret? indicando um noro time constans) entre forma e materis, so guindo Bonity. Index Aristololicus. CI. sua traduçao de Metal/sica. Paris. Vrin, nota ad ioc., 1953, D. 123.

3 Natureza, nesse contexto. umplica a lorma das coisas "lal como oxpressa enr sua deliniç̧A, isto $\diamond$, com o carater gue possuom ao chegarom a seu plono desonvolvimonio:. Entretanto, com portn tambam o significado de um Tormo coletivo que abarca as natureTormo colollue que abarca ns naturezas de 1060 os corpos naturais que W.D. Ross, Atistotie. Londtes, 1923.

4 Tricot observa ser este o sentido prim cipal -... II no s"agit que des Atres cipar .... II no sagh que des otres sut phy'ser". Melaflsica, $1023 \mathrm{~b} 27 \cdot 27$, nota ad loc.
} 
5 C1. A Mcrnigitano. Contribuso aila sto is degh stud ciesssti deimondo an di Storia - Lotioratura.

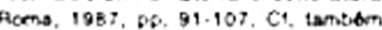
Droit nature' et dignite pumane $E$. Bloch, Paris, Parst, 1976 , D. 119.

B ideojogie dé ciassicismo. L, Cantora. totino, Einaudi, $1000,00.182 \cdot 4$

? como o 'nz Giots, net arompto, ao acontal o orro" de Coulanges Corr borta a teoris scminante ns exols is. cial to itu to $x$ ix

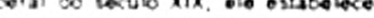
uns antingmas absoluta entre a on

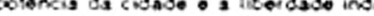
moual. quando of. ao contratio, no metro casso a volando ie um no cutro ave o poder cloltico o incer

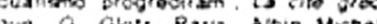
$1958,2,13$

g Para uma notkia nissorica das toocias woie as orgens da zariedade, Cr S.G. Pemplote Tho oally puman ta. mily tome vinwe $1770.1870^{\circ}$, in $A, A^{\circ}$ Holgal. (od,), Classical intluences of wostern thought. Cambidge. 1979. Oopois do um soculo to silancio, Ba hoton toacendou o caloresso pola or. canis

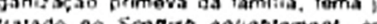
ra moado so seculo XVill, con Acam for Guscon - Join Metlet, Siuas deravisas. entora orverginso guanto ac estatuso da muther. apontan bars um ostagoo originstito de celactos promlkuas or unbes coletoras, cotrelacionando co ment raturnes'

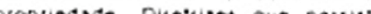
an not tratestor coverioger a 1850 at Chales foutiot o ens omonas de evalus do soxisl, onde o osisgos simitro de phanerogemis dolapalexo

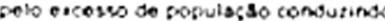
a oropredace piraca o co casameri

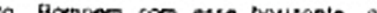
do

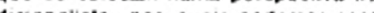

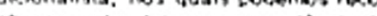
nhecen, os hardeires por arcosncia do Acisiotates. Em dieno sculo xvili. lord kames sparece com gramie in Hutras. partingo das citoronsas to valis o pement, audecioso - bito

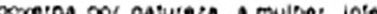

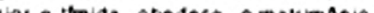
en or doligamia como formn de casamenco. - fa o peboria de selvagons. jamais co nnocicas polas nascos ouropolas do Norte.

9 Probiamms onistorrographie ansionne ot mojeine. A. Mornigliano. Palls. Gallmard, 1983, O ausot teconatitul amsionte untelectual, os compromissos Dolficos a a trafitioibncia, para os astudos mediovais, das me

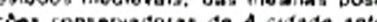
sa. A odrso desse obra, aqui vitis. do. de tisoos. 1950. Os nimaros entie osionieses. no corpo do torto. comencoessem as asginas desso olu $\infty$.
Mas nas consciéncias dilaceradas pelo impeto revolucionáro e contra-revolucionáro que entrecortou o sêculo XIX. o espaço manteve o seu priviégio estabihzador. Nesse contexto, deu-se a "volta aos gregos", com toda a ideologia de sua repousante beleza. Anstoleles desempentou af um papel estrategico, olerecendo a magern global de um mundo eletivo (nåo de uma estera trans. cendental, inacessivel ao comum dos mortas), um mundo humano potencialmente aberto (porque já carregava em seu interior a pacilicaçáo dos choques) ao exercicio de um poder acerto pelas consciencias dominadas, submetidas a uma hierarquia natural.

As idealizaçőes de um universo igualizado, "democrático", ou deliniclo pela escala do poder legilmo, repartiram a herança arıstolélica da comunidade primitiva, onde roınava a ordem, a integraçào natural das funçס̋es, as virtudes organicamente desempenhadas pelas partes ce um todo cujo fim úlımo era o Bem Comum, a telıcıdade geral.

Na historia das ciẽncias humanas, Bacholen representa um divisor de águas nesse sentıdo. De ınicıo ingado aos movimentos românlıcos, por causa mesmo das pesquisas suscitadas por seu Mutterrecht, entrou ern contato com a obra de L. Morgan, assim como de outros estudiosos angloamericanos. A intlexåo solrida por seu trabaiho e a importancia que, junto com The ancient socrely, assumiram na obra de Marx e Engels săo notórias ${ }^{(5)}$.

Năo tanto pela influência de Bachoten, mas pela freqüentaçăo das obras atistotelicas, a socrologia herdeira do Romantismo, na Alemanha, leve os seus rumos inclinados para a oposiçăo sistemática entre a comunidade hamoniosa, consubstancial ao espaço e organicamente integra, e a sociedade, tragmentada por contradiçðes insolúveis, sujeita à destruiçåo. Nåo será preciso insistir no quanto essa deologia conservadora sustentou as representaçoes - e sustenta ainda hoje - sobre a sociedade brastleira (sua crítica teceu o fo condutor de minha tese para livre-docencia).

A separaça entre a face organica do mundo primitivo e o mecanismo devastador da sociedade moderna operou-se, com toda a clareza, no pensamento sociologico francès. Durkheim sur. ge a lembrança, nesta conjuntura. Mas um de seus mestres, Fustel de Coulanges, efetivamente lançou as bases para uma doutrina ao mesmo tempo positiva e romântica das sociedades antigas e. por oposição. das modernas. Deliberado continuador de Aristóteles, suas teses, veremos. sảo arraigadamente tradicionalistas e contra-revolucionáruas.

Introduzindo A cidade aritiga no quadro poltico e intelectual da época, L. Cantora assınala a fundaçåo religiosa dos agrupamentos humanos como seu ponto de partıda. Consıdera as teses de Coulanges visadas nos ataques de $\mathrm{E}$. Meyer ao ideário que interliga cullo dos antepassados e unidades gentilico-sacraıs, dal remontando às associaçø̄es comunitárias anteriores ao Estado. Certa loitura de Aristóleles teria lavorecido lais inferências: o Eslagirita, embora colocando corretamente o Estado como portador da natureza humana, desenvolveu sua gênese a partir de unida. des menores, nascidas da célula mínima, a tamfia. Aında, segundo Meyer, a instifuiçăo estatal é onginária e. contrariando essa evidéncia, a etnologıa absorvera o legado aristotélico de permeio corn equivocos teóncos. Pretendendo limitar-se à investigaçăo empírica, havia recebido, ao mes. mo tempo, premissas extracientfficas, ligadas ao "modemo Liberalismo", assim desvinculando o ındividuo do Estado e reconstituindo as formaçß̌es sociais primitivas. Esta afirmaçāo do individuo contra o Estado - tese de extraçăo e essência liberaıs - se teportaria aos axiomas sobre o aparecimento recente daquele organismo na históna humana, precedida por um longo perích no qual a base associativa lora a dos laços sexuass e consangülneos ${ }^{(6)}$. Diflct saber, nesse intrincado campo ideológico, quem melhor representa o conservadorismo autorilário: se Meyer, com a eternidade do Estado, se Coulanges, com a sacralızaçăo da essencia comunitária.

A herança arıstolélica de Fustel de Coulanges é evidente e reclamada por ele de modo expresso. Impossivel aceitar, porêm, que suas posiçठes tenham qualquer afinidade corn doulrınas liberaıs $^{(j)}$. A aparente concidència tética - deprimur o Estado - deriva de pressupostos radicalmente diversos no Liberalismo e na obra de Coulanges. Em momento algum este último busca "exaltar o individuo", em nenhuma vertente sequer contratualista. procura, antes, de uma perspecuva ultraconservadora, afirmar a preeminencia da lamnia contra loda forma de comunismo primitivo, seja do ponto de vista do casamento ou da propriedade ${ }^{(8)}$.

A orientaçăo de suas pesquisas imprmiu marcas prolundamente relrogradas no desenho de A cidade antiga ${ }^{(9)}$. Sua raiz mestra, como se sabe, é o culto dos mortos e do logo sagrado, reun!dos no lar (hestia), deus benfazejo. O vinculo entre a famfla, projetada nos laços com os ancesIraıs, e o recinto que habita, náo podena ser mais completo e sacralızado. Origern esta que não é circunscrila aos gregos, mas comum a romanos e indus, da mesma raça anana. O método comparalıvo al exerce toda sua torça, a serviço de encontrar, para o Ocidente, seu mais remoto fundamento. (pp. 33-39)

Nessa réliglåo primitiva já é possivel entrever elementos normativos especificamente humanos: quando o mito do logo sagrado metamorfoseou.se om vesta, a deusa náo assumiu frguras de 
fecundidade ou poder, mas de ordem: năo a regularidade inexorável da natureza, mas o obrigatorio no plano moral. Coordenadas que definem os entes humanos essencialmente pela referência à famnia, vista pelos prismas religioso e ético. Coulanges esmera-se em afastar a religiăo primordial da exteriondade fisica, mescla que poderia esmaecer este cerne de representaçoes familiares e seu endeusamento. (pp. 40-42)

Estabelecida a comunhão entre mortos e vivos - consagrados na farnilia - começa o processo diferenciador do parentesco: o culto é prestado exclusivamente aos defuntos consangüfneos. Com isto, ressahtam as marcas contra "os de fora", aumentando a coesăo interna do grupo. "Um poderoso laço se estabelecia unindo todas as geraçőes da mesma farnnia." (p. 45) Reconhecimento da descendência, que prepara o terreno para a instauraçåo da propriedade. A começar pela posse funerária: a mesma tumba, privativa, reunia toda a tinhagem. Em eras remotas, este centro dos cultos vinculava-se ao logo sagrado, apanágio de uma so casa, de uma so lamilia, com seus ritos intimos. A religiăo doméstica revela-se um "patrimônio, uma propriedade sagrada". (pp. 48-50)

Progressivamente, esta idéia de propriedade consubstancial à lamnia e à religião vai assumindo contornos mais ninidos. Do interior do lar, essa trilogia estende seus braços: proximo à casa situa-se o túmulo dos antepassados. Novo e lorte acento é posto na continuidade e integraçáo farmiliares, definindo linhas geneakgicas: a filha casada separa-se dos parentes, o filho emancipado é exclufdo. A consistência do grupo social é garantida pela propriedade: "as leis de sucessão traduzem, o mais exatamente, as idêias dos homens sobre a tamnia (... $)^{\prime \prime}$. (p. 54) Como derivaçăo necessária deste todo coeso, o matrimónio é monogâmico e indissolúvel, elemento portador das tradiçðes. (pp. 69.77)

Explicitam-se finalmente as consequeencias dos pressupostos e desenvolvimentos da pesquisa: "Há très coisas que, desde os tempos mais antigos, encontramos solidamente nas sociedades gregas e italianas: a religiảo doméstica, a lamilia e o direito de propnedade". Este último in. tegra-se ao sisterna de atos e representaçðes piedosas, com seus ritos em homenagem aos deuses jacentes à lerra: o lar, símbolo da vida sedentária, preso ao solo, năo deve ser deslocado. Como ele, o grupo ocupara sempre o sfito "que the pertence, propriedade năo só de um homem, mas de uma famnia, cujos membros devem vir uns apos os outros, nascer e morrer ali". (p. 84)

Nenhuma relaçăo, portanto, com propriedade individual e negociável. Nenhuma sintonia com os fundamentos do Liberalismo, tal como propostos, por exemplo, ern John Locke, pensador de grande importancia nas Luzes. Em sua doutrina, os espécimes humanos singulares - componentes do conceito geral de classe - exteriorizam sua propria atividade transformadora da natureza, dela se apropriando, legitimamente, na medida desse poder intrinseco aos sujeitos. Ao quadro laico exposto no "estado de natureza", ao privikgio do particular que se diferencia no processo aquisitivo, opઠ̋e-se a concepçāo acima definida, onde a propriedade, sacralizada e intransferlvel, se inaugura com a laminia. Sua duração perene é correlata ao encadeamento perpétuo da paren. tela: ambas sâo indivisíveis e tāo imóveis quanto o lar e o túmulo a que eståo presas. A noçāo de culto familiar leva ao requisito de isolamento frente a outros núcleos domésticos: donde a necessária vedaçåo em tomo da casa, "sebe, paliçada ou muro de pedra". Tal parede, levantada pela religiåo e por ela protegida. "afirma o tributo mais verdadeiro, o sinal mais irrecusável do direito de propriedade". (p. 86)

As tintas ultraconservadoras năo podenam ser mais carregadas: a conotação simultaneamente biologica, social, religiosa, espacializada e economica se traduz, em conjunto, pelos laços consangülneos e costumes unificadores das geraçōes, pelas linhas sucessónas conexas à propriedade exclusiva do espaço. Casa, famnia, tradiçăo, o sagrado e a propriedade: recorte analítico em Fustel de Coulanges e nas batidas veredas do trocínio tradicionalista, que universaliza o prin. cípio teologico-poltico.

Os estudos sobre comunidades, corn criticas ao capitalismo à direita e à esquerda, em proposiçঠes teoricas ou pesquisas emplricas, prolongaram o aristotelismo, romántico ou positivista na melhor das hipoteses, religioso e inadvertido na maiona das vezes. Mesmo em estudos sofisticados, nos herdeiros de Gernet, por exemplo, nâo é difícil discernir os pressupostos de religiosidade, representaçóes miticas, e vida comunitária arcaicas, opondo-se ao mundo progressivamente desencantado num processo crescente de pensamento racional, prosalsmo, vida urbana, politica democrática. 


\section{A imagem da oikla como edificio e familla}

O livro I da Poltitica apresenta a polis como um composto de partes dessemelhantes, um todo identificado a uma unidade natural, contrariamente às teses sofistas, segundo as quais lei e Estado săo estabelecidos por convençăo, ou ao projeto clnico, onde o homem, cidadăo do mundo basta-se a si mesmo ${ }^{(10)}$. Dentre a variedade de contextos em que natural pode se inscrever, um duplo sentido - genético e logico - configura-se na relerida passagem, como polos a sustentar a argumentaçăo("1).

As implicaçôes genéticas predominam na medida em que os vínculos primitivos e necessários entre homem e mulher, senhor e escravo, sâo isolados como elementos últimos, indecomponiveis, da cidade. Se essas "menores partes do todo" săo irredutlveis uma à outra, e se a teleologia que as governa encontra seus limites em alvos distintos (reproduçăo da espécie, subsisténcia e segurança), essa divisăo ê compensada pela continuidade espacial da casa que as unifica e as funde num conjunto fisico e social mais complexo. Donde a exatidáo e a força do termo okkos. nessa análise: ele designa tanto a taminia quanto sua morada, compreendendo não só o agrupamento social do chete, seus descendentes e servidores, como também o ediffcio onde se instalam.

E. Benveniste examina o vasto conjunto etimologico tradicionalmente estabelecido em torno da noçấo indo-européia da casa. Em sua crftica logo reconhecemos aspectos do ideário estranhado na própria montagem desse conjunto. "À primeira vista, essa grande reconstruçăo etimologica, onde entra um grande número de lormas tomadas a todas as linguas da famflia, nåo coloca nenhuma dificuldade maior. As relaçరes supostas săo, ao menos, plausiveis." Esta mesma verossimilhança jấ acusa as linhas mestras da interpretaçăo: "Pode-se, inclusive, achar natural que

$10 \mathrm{Ct}, \mathrm{D}$, Ross, Ansnotie, Eo. cit

11 Poitics, 1, 1252a 24 - 1253s 29. Aristoreler.

12 Vocabulatio de las instituiciones in doeurocdias, E, Benveniste, Nadric. Taurus, 1903. D. 195.

$13 \mathrm{Cl}, \mathrm{p} . \mathrm{ex}, \mathrm{L}$ religion poputaire dans la Greco antique. M, P. Nitsson. Paiis, Montort, 1955. Vet o Capflulo "L maison at 19 tamille $0^{\circ}$. Cur introducso

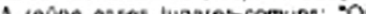
gregos anboos teriam compreendido - seritido do nosso adagio: o homem no lar, esta om seu castelo". (o. 110) Perspectiva que abarca as interpretacoes reguintes as magens de Zeus protetor da casa sto esciarocidas pelo eptroto de "Pai" encontrado no (a)

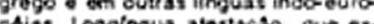
civi a kbaia 60 "Zous dai dos homens - dos douses" na distante pet-histo is nao noure uma nobreza auto-2s. ctalizadora nem os nomens ou 0 mundo tor am criados dor Zeur. Alas tados esses senticos "fisiologicos". cesta tmediatumente o clicha lamin e sua sede: "Em coneger a tam cia, o eptrets deve designs.to como pater tamilias. O chete de tamnia, o que concorda com as condiçeres so. ciais, patriarcais dos povos indo-our ropeus. Por isto, Zaus a protator por excoloncla da morada". (pp. 118 . i19)

14 Benveniste distingue as rafzes fom (o), "construir" " com - "Tamnia", considerando as irrecutho is e notas econhecendo apenas nomotonia. Eecomplo de "contaminasso", no grego nombrico, o dado por do (m). "ca. Lar tamnia" - conds, "casa-constru. \$30". A sou ver, a transposicalo de sontidos atetou outros termos totors cos s rexiecide como "nas bermas do ine machal iwe como has lormas quo donotam a unidado iormada por Valias tamnias", 0 culo sontido zou para o aspecto materiat do grupo de casas, baiffo. burgo". Nessa trama, o grogo (w) inas ocupa uma po sicaso intermediaria: em primeiro lu. gar, (grande) casa, "que agrupa lode a decendoncia do chete de tamnia

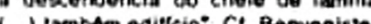
OD. cil. PQ. 200-201.

15 E, Benveniste, Op. cit., pp. 201-202. um nome que designa a 'casa' e é comum a quase todas as linguas, proceda de uma raiz verbal igualmente antiga, que significa 'construir'. Deduz-se, dal, que a primeira unidade social, a 'casa' ou a 'famfia', deveria seu nome à técnica material do trabalho em madeira para construçấ.4(12).

Náo é dificil atinar com as implicaçőes valorativas dessa genealogia: supor, para todo esse grupo léxico, a mesma ascendência remota, geradora de um campo semantico unificado pelas imagens de abrigo e proteçăo, está a um passo de subentender a "famfia vivendo sob o mesmo teto" como a célula social ${ }^{(13)}$. Toda uma aura pacificadora envolve esse horizonte imaginário do habitar em comum. $\mathrm{O}$ ato de construir, visto como princlpio na cadeia de representaçð̋es familiais. figura desfgnios, conhecimentos e atividades dirigidos para acolher nucelos consangülneos ou afins, internamente coesos, limitados e estáveis. Estivessem em jogo outras conjecturas, por exemplo, lossem os bandos primitivos imaginados como efẽmeros e constituídos por práticas predatónas, ou coletivos no referente a sexo e propriedade, a famflia deixaria de seguir-se como pressuposto orgânico do social, seja enquanto base biologica, seja enquanto instrumento de autopreservaçåo.

As ideias integrantes da liga natureza-artefato, intormada na casa, de certo modo incidem sobre um efetivo ponto de inflexăo na história do vocabulário e das instituiçð̋es gregas. Embora Benveniste desfaça, meticulosamente, o aglomerado kexico que reúne parentela e recinto material, separando as séries provenientes das raizes relativas à casa-ediffcio e à casa-familia, também reconhece "contaminaçర̄es" entre essas formas, indicando, no grego, uma tendencia para identificar o agrupamento humano e seu habita (14).

Ao longo desse processo, em que o nome do segmento social se transfere para sua base fIsica, Benveniste capta "um grande fato de civilizaçăo, inclusive mudanças nas instituiçరes, que o vocabulário traduz indiretamente". Na Grécia, a linha decisiva desses avatares passa pelo "fracionamento da famnia grande em familias distintas". Relomando um quadro evolutivo onde lingülstica e antropologia se cruzam, Benveniste afirma o caráter originário da farnfia extensa, carente de propriedade individual. Uma vez rompida essa formaçăo e dispersos os filhos, "os termos conotatvos da familia grande se empregam cada vez menos, a própria noçăo jấ năo corresponde mais à realidade da instituiçâo (...)". A pólis - onde, por excelencia, espaço e sociabilidade se integram completa o movimento que "aboliu lentamente os quadros sociais anteriores em proveito de novas đivisőes, agora territoriais. As antigas divisőes sociais, fundadas na ascendência genealogica, 10ram progressivamente substituldas por agrupamentos determinados pelo habitat comum"(15).

Com o descortino favorecido por "um acontecimento global imenso" - a particularizaçăo das línguas indo-europêias nos seus aparatos semânticos e contextos culturais diferenciados - Benveniste opóe-se às teses iniciais da Polnica: Aristóteles apenas "codifica uma situaçâo jâ adquirida" quando vê, no oikos, a "menor tração e a primeira forma de sociedade que existiu" e, dessa ongem, "imagina que se passa â aldeia, kömঠ, e à cidade, polis". Em seu entender, a "reconstruçåo que parte da célula social e procede por cruzamentos sucessivos é falsa. O que existiu desde o princlipio é a sociedade, essa totalidade (...). Mas Aristóteles converte em condiçăo universal e 
necessidade filosofica aquilo que a sua propria sociedade the apresenta: projeta no absoluto um estado historico"(16).

Atravês dessa análise, podemos discernir, no texto anstotélico, as mais típicas figuras hoje denorninadas ideologicas. Um raciocínio classificalorio, estático, rebate-se nos processos sociais, abrindo campo para uma dupla operaçăo: inverter o movimento histórico, tomando os resultados pela gênese e, por conseqüência, engir o particular em universal, legitimando o status quo. $O$ reconhecimento, em Aristóteles, dessa operaçăo ilusória, năo poderia constituir anacronismo, pois que ele próprio a acusa nos debates dos Tópicos, ditando como discernir "se o proprio da parte nâo ê predicado ao todo"y17).

A mesma generalizaçăo imprópria ê discutida no estudo de Benveniste sobre as Categorias. Já em sua hipótese, destaca-se o fundo particular sob o teor universal das propriedades seriadas naquele texto: "Aristóteles, de fato, raciocinando de modo absoluto, reencontra simplesmente algumas das categorias tundamentais da tingua em que pensa"(18).

Submetidos a cuidadoso exame, cada um dos termos logicos incluldos no inventário de predicados recebe, com efeito, sua transcriçấo em termos de lingua, verificando-se a preeminência destes últimos sobre as atribuiçőes. As análises de Benveniste também se validam por esclarecerem os fundamentos da ordem impressa âs Categonas, nem sempre discernidos de modo preci-

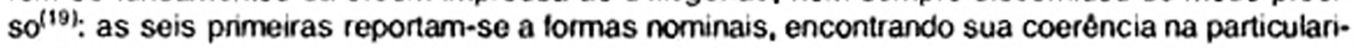
dade da mortologia grega; as quatro últimas referem-se a formas verbais, igualmente transpostas a partir de suas especificidades no grego. Nos dois casos, os predicados náo correspondem a atributos descobertos nas coisas, mas a uma classificação emanando da própria língua ${ }^{(20)}$.

Certos pressupostos que sustentam essa análise surgem explicitos, de modo mais amplo, em outros escritos de Benveniste: "Pensamos em um universo que a lingua modelou antes. $A$ variedade da experiència fílosoflica ou espiritual está na dependência inconsciente de uma classificaçáo que a lingua opera pelo simples fato de que é lingua e de que simboliza ${ }^{\alpha(21)}$. Esta chave completa-se por outro tado: "lodos os momentos essenciais da lingua têm um caráter descontínuo e pöern em jogo unidades discretas" ${ }^{2(22)}$.

Inconsciente, classificatoria, descontinua: determinaçőes da linguagem e linhas de força nos argumentos de Benveniste sobre as Categorias. Em seu arcabouço. Aristóteles reiterou o trabalho distintivo inerente à linguagem, ao inventariá-las "sob condiçăo de que cada termo losse significativo em estado isolado". Por isto mesmo, nenhum principio sistematizador dirigiu suas escolhas: que apenas pronunciam, no discurso filosófico, as matrizes jâ prescritas nos signos. "Inconscientemente, ele tomou por critério a necessidade emplrica de uma expressăo distinta para cada um dos predicados." Excluindo o ato propriamente inovador para o qual se abre o exercicio da lingua - o agenciamento singular de suas estruturas - ${ }^{(23)}$, limitou-se, mais uma vez, a colher resultados. Fadou-se, portanto, a "reencontrar, sem querer, as distinçōes que a propria língua manilesta entre as principais classes de formas (...). Pensou definir os atributos dos objetos; pos apenas seres lingüisticos: é a lingua que, graças às suas próprias categorias, permite conhecê-los e especificá-los"(24).

Ao techar a questăo proposta, Benveniste aponta, de maneira feliz, para uma das fómulas mais recorrentes em Aristóteles: "É o que se pode dizer que delimita e organiza o que se pode pensar". Legetai... escreve ele, vezes sem conta, inclusive ao introduzir os problemas mais espinhosos e decisivos de sua filosofia. Tudo somado, na elaboraçāo das Categorias, "a língua fornece a configuração fundamental das propriedades reconhecidas pelo espirito para as coisas. Essa tábua de predicados informa, portanto, antes de tudo, sobre a estrutura de classes de uma língua particular". Neste ponto, reconhecemos a carga ideologica depositada no discurso aristotélico. mesmo onde ele poderia revestir-se, em grau máximo, de aparente neutralidade: "Segue-se que aquilo que Aristóteles nos dá por um quadro de condiçŏes gerais e permanentes é apenas a projeçăo conceptual de um estado lingülstico dado"(25).

Completa-se, assim, um movimento análogo ao já visto para o começo da Politica: ater-se à imediatez do resultado, transpor o particular para o universal, reiterando o existente. Desenlace que revela as posiçðes conservadoras de Aristobteles: elas não se configuram apenas nos aspectos doutrinários mais conspicuos (como a origem absoluta e natural da farnilia), mas se entranham nas profundezas de seu raciocinio (como nas "categorias do ser") ${ }^{(26)}$.

Atentos para o alicerce positivo das teses aristotelicas sobre a gênese das coletividades humanas e acompanhando a reconstituiçăo empreendida por Benveniste, podemos aduzir as sig. nificaçōes recolhidas e ampliadas na Politica: elas prendern-se ao momento em que o ofkos acumulou, aos valores sociais já presentes na prê-história do grego, as determinaçóes de lugat que situa, congrega e abriga a parentela, com o nome do grupo humano transferindo-se para o habitat que o limita. O espaço e a proximidade física apóiam, literalmente, as meláloras do espaço e da proximidade sociais, sobrepondo-se as duas esteras. Em suma, a espacializaçåo fundante no
16 E. Benvoniste, op. cit., p. 202. "O que exlativ desde o princlpio a sociodado. ossa lotallidade." Esta opt niso o partithada por outros helenis. tas que se elastam dos partmotros conservadores, Vet, por exomplo. ainda, v. Ehremberg. LEtat grec. Maspero, 1976. Sua reconstivikso do mundo grego pressupde ims "co munidado primitiva" de onde saltam. pouco a pouco. "a lamnia individua da oncos in o kleros, propriedade porvada" (Pp. 35-36). Sous argumentos incluem as ressalvas do verossimir. E nesse ponto, o nato pelos motivos avontadoe por $P$. Aubenque (ver $n$. 26) qua a lese do Benvenista pode tornar-se vulnerável. As lormas petmittras da sociabilidade humanas permanecem tao hipoteticas o con jecturais quanto na logica mvolucio nista. Mesmo para opocas menos to cuadas, relativamento, a carbencia de inlormacbes resulta om tragilidado interprotativa. Voja-so. por oxemplo. as cinicas de R. Lomis a S. Reinach. sobro o sentido dos troteus: "sou procodimento consiste om teconstitui praticas que se supbe lerem oxistion om epoca primitiva, para expticar o tho cujo significado nos escapa". Cl. Guerte el religion on Grace a rispo que classique. Paris, Botles Lettres. 1979. B. 130.

17 roptcos, v, 5, 135a 32 - 1330 1 - Aquele que indica como proptiodade do at ser resplisvel, indica a pro peledade de algo que consiste om partes someihantes. mas indicou um atributo tal que. embota verdadeito para algum ar, niso os predictuvel para - todo (pois o todo do ar nito o rospi todo lpois o todo do ar naso o respt. lavol) o assim reapirável no serd

$10 \mathrm{C}$. Catopories de pensde el catogo ries on langue ${ }^{\circ}$, in E. Benvoniste. Problomes do linguistique gondralo. Paris, Gallimard, 1966. p. 60. A intorprotaça de Bonvenisto opoe-se trontaknente P. Aubenque. Esto aulo localiza as desconfianças contra as cateporias onquanto conceltos a prio. ic. minimamente organizadoros da - minimonte da oxperiencia, a partir de Kant, quo univorzariza subropticamento e. dal. que sao de tato historicamente ligadas a urna corta organizasso tecrica properin a ciendia de seu lempo". Mtu. catis mutantis, a mesma suspoita projostou-te sobre as calegoriss de Aristoteles, Iniciando-st. com Tra.

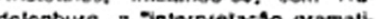
cal das colegorias". onde estamatcal das casogorias" onde estas renetem uma certa organizacso da linguapern. Do modo contundente. Aubenque anota: "Isto foi redescobetto mais do com anos depois por $\mathrm{E}$. Benveniste (.... .

A lorga de sua arremetida liga-se a propria gravidade da crtica empre. ondida, on ondida, de consequoncias desastrodas categcelas depondentes dos 16 . nomonos lingoisticos - das particularidades de uma lingue - a negar-thes toda protonsao a universalledade. Sua "dotesa" das categorias - legado grego - procura invertor a questso e modianto ums antocia lodrice - nto nodian uma abtocin tocilca - nac margu. mentos: Pois se as categocias onto10 gicas pareceen dorivat das catepo. tias gramsticais, o na verdade pos. que estas constitufrafm 20 tardiarnente - nurra boca em todo caso ponserior 4 Aristoteles - sobie a bate do una

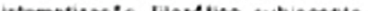

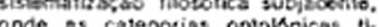

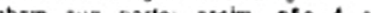
nham tun parte assim. nso o a wo, mas ames at calogoria pramatica! 
do substantivo que tollote uma corta idela filosolica da rubstancia". CL. P. Aubenque (od.). Concepta el caldgo. ries dans la pensde antique. Parts. ries dans id pensde antique. Parts. Xiti, 1980, p. XII - note I, P. Xiti.

A ceftica acima naso dos mais foll. zes. Antes do tudo ola attibui a Bon. veniste o equfvoco de contundir a bs. trutura - enprego oletivos on lingue - objelo de seus multirarios a cerra. dos obludos - com gramatical. Mas, mosmo nesto nNel. o argumento - as calogorias gramaticais sao posterioros a Aristoteles passa ao largo do alvo. Os naxos on tro essas duas areas nAo suportam onunciado assim cortanto. No proprio Estagirits, os codipos de pensamento Estajar os codipos de pensamanto Para ticar num oxemplo: verbo ao substantivo como aquile que significa ademah o tempo". Aris. tóteles da um passo importanto om di. tecslo $\Delta$ gramatica no sontido om que 6ssa disciplina - tal como ro aistema. tizarA en Alexandris no 11 o 1 acculos - abre um grande lugar 10 estudo das lormas das dilerentes parsos das tomas discurso". Ct, Ansatole, La podtique. Texto, traducion, notes par R. Dupont-Roc o J. Lallot, D. 331 .

Evidenternanto, o problema do con. tato ontre esses dois campos trans. cende o grego. Um caso exomplat. pelo pressuposto de hudar-se princloios universats principios universais o polas tintas ideolica ugica atistotsilica come bnte da gramatica Arabe. Os soculos de anterioridade do Oeganon a tortuna de suas traducdes tornatian plausfve essa perspectiva: entrotanto, nam do conto de rista historico, nem nioson.

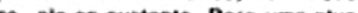
ElamraniJamai. Logique aristotolicienno of grammaire arabe, Paris. Vrin. 1983.

19 Th. Gomperz (Pensadores griegos, B. Ayres, 1952, y, 3, 00, 49-50) lembra o comentario de Kant, ao aprosontar suas proprias catogorias. Este con trapoe seu extremo culdado em nso estabelectlas "rapsodicamente", modo fortuito de Aristotoles que. "nso tendo nenhurn ptinclpio, as apannow acaso. COmo se apresemavam acaso. como se apresemavarn C.... . . . Kant, Krient dor ros nuntt. F. Meiner Vonlag. D. 118 CT rad G. Gentile e G. Lombatdo-Radico, Bari, Latorza, 1981. p. 115) Cl, tambenn D. Ross, Aristotio. Op. cit. Ao assinalar gue Tradelenburg jo dert vava as Categorias do diatincoe vavaticais, Poss gramaticals. Ross admito as fomas Aristoteles, ressalvando que "sua doutrina das categorias reóne coisas que a gramatica separa o separe cotsas que a gramatica roùno".

20 Expressoos roloridas a formas nomi nais: ous/a (subatancia), substantivo poson, poidn (quanto. qual). adjetihos derivados de pronomos pros (relativamento a aue). (relativamento a que), adotivo comp paravro. poo, poll (ondo. quando). tempo. Expros. soos releridas a lormas verbais: ketsthai (ostat om postura), modio ochein (estat om ostado), portono. poiefn (fazer), ativo; paschein (sofrer), passivo. Para loda ossa discur sdo, ct. E. Benvenisto. Op. CiL, Dp. 65-70.

21 Tendences idcontes en linguistique gentrale", in E. Benvenisto, op. cit. p. 6.

22 "Coup oroeil sut to debreloppement de ta linguistique " in E. Bonveniste, $\infty$. dit., D. 29.

23 -A linguagem reproduz a realadade. pensamento pollitico de Aristóteles é correlativa - de modo fantasticamente direto - ao seu acordo com o estado presente das coisas, no plano da lingua e das instituiçōes. Esse vinculo originário entre espaço e sociabilidade é mantido ao longo de suas doutrinas sobre o desenvolvimento da vida civica.

\section{Discurso clentfifico na Fisica: polêsis establibrada}

Discemida em Aristôteles a imagem conservadora da casa como princlpio de organizaçăo social projetando seu próprio meio politico - jogo de espelhos que năo é isolado em seu sistema, incidindo sobre outros planos, como nas Categorias - vejamos mais de perto o vinculo entre espaço e sociabilidade. A fusão entre casa-famllia e casa-ediffcio poderia mostrar-se algo insólita, quando lembramos que o primeiro teixe de significaçóes incide sobre o plano natural, enquanto o segundo se decompóe no prisma técnico. Entretanto, em que pesem os contrastes entre physis e têchnē. Aristóteles estabelece também paralelos entres ambas, em aproximaçőes garantidas por seu finalismo(27).

Note-se os contextos onde, na Física, oikia ${ }^{(28)}$ é apresentada apenas como artelato, como exemplo daquilo que $\hat{b}$, literalmente, manufaturado (cheirokmetos) ${ }^{(29)}$. Nesta passagem, enquanto casa elaborada tecnicamente, oikía recebe o estafuto exclusivo de objeto inanimado, que supōe o desfecho de uma atividade artesanal anteriormente realizada. Nesses temos, enquanto érgon, ela é o resultado de um movimento: "Nāo o que está se tomando, mas o que se tornou, năo o construir, mas o ter construido, não o presente ou o aoristo do mover-se, mas o perfeito de ter movido ou de ter sido movidom(30). Neste comentário, inserido na discussăo sobre ato e movimento em Aristoteles, Aubenque explora, abstratamente, os sentidos denotados pelos tempos verbais, seguindo as normas estillsticas e projetando, é certo, vias sugeridas em seu proprio objeto ${ }^{(31)}$. Se o eminente intêrprete segue um rumo engenhoso, perscrutando, no Estagirita, a correspondência entre discurso humano e natureza das coisas, năo é seguro que se possa permanecer, com ele, no limiar daquelas marcas genéricas fixadas na conjugaçăo grega.

Voltemos ao exemplo da Física, observando mais de perto os tempos verbais, tal como aparecem efetivamente inscritos na cadeia significante do texto. A exposiçăo que distingue entre seres da natureza e coisas artificiais coloca o exemplo de oikla num campo sintático e semântico onde seria plausivel o uso do perfeito, enfatizando o caráter definitivo da obra, a permanência de um destecho durável, como "estado presente de uma açāo anterior ${ }^{m(32)}$, isto $\theta$, do processo de construf-la. Nâo obstante, nessas frases os verbos concentram-se no presente: um indicativo presente enuncia que nenhum artefato carrega (échei) em si mesmo o princlpio de sua produçăo; depois, um particlpio presente designa o objeto técnico: to poioúmenon. Nada precisa a idéia de que a casa "foi leita e mantêm-se neste estado". Ao têrmino deste trecho surge ainda um optativo presente com valor polencial (génoit'àn), aventando a contingência - expressa agora por um partićpio perteito (katá symbebēkós) - de que uma produçăo artistica seja causa de si própna.

Neste ponto, o trånsito para o perfeito nåo evoca, imediatamente, limites temporais em que os verbos se inscrevam, mas projeta no plano logico um traço particular e corrente da língua: 0 particlpio empregado em relaçōes atributivas é recolhido, por Aristóteles, numa fómula conceitual, katà symbebẻkós, por acidente, na traduçåo consagrada. Entretanto, se ficarmos atentos ao sentido vernáculo, năo raro embutido no vocabulário técnico de Aristóteles ${ }^{(33)}$, lembraremos que symbainein deriva de bainein, tendo em mente que "os termos dessa famnia de palavras se reportam à noção de andar (nâo de ir) ${ }^{\text {*(34) }}$. Desse ângulo, tò symbēbekós se deixaria traduzir, numa "perffrase literal", se me permitem o paradoxo, "por aquilo que andou junto e existe em compasso", designando certo liame de concordância, durável mesmo, entre o "acidente" e a ousía a que se relere, em vez de apenas uma coincidência imprevisł́vel e efêmera. Assim, o particípio perfeito, precisando a maneira como o atributo se constitui, nāo quebra a série de presentes, mas os sublinha, sendo, como eles, indicativo de algo permanente (este é um ponto delicado, a que voltarei adiante).

Já no parágrafo anterior ${ }^{(35)}$, onde săo definidos os seres naturais, diferenciando-os da atividade poética do homem, ocorre uma grande predominância do presente. Em 16 linhas, há 19 verbos (o que pode ser considerada uma incidência nomal, para alta), dentre os quais, 15 do presente, coadunados a 4 perfeitos ${ }^{(36)}$. A dominância cont'́nua, cerrada, do presente, monta um jogo de cena: antes de instruir sobre qualquer dimensáo cronológica, ou mesmo sobre qualquer figura temporal, traz as informaçōes para o primeiro plano, iluminando-as nitidamente para que as diferenças possam ser estabelecidas com clareza.

Tamberm al, a transição para os perfeitos concatena-se a ordem mais ampla do texto: a marca do alual e do efetivo que the é intrínseca torna-se acentuada pela série de presentes que os enquadram, nas linhas anteriores, intercaladas e subseqūentes a eles. Os infinitos - inclusive pelo 
sentido, no caso de eínai - enunciam o estado puro e simples dos fatos, abstraçăo feita de sua temporalidade. O entorno onde se localizam melhor marca essa idéia: os dois últimos infinitos encontram-se num contexto explicativo das proposiçōes articuladas antes e depois deles: $o$ artefato náo possui (échei) tendência inata à mudança; a natureza é princlpio e causa do mover-se e do repousar (toù kineisthai kai ēremein); na coisa em que existe (hypárchei) perse. Nesse bloco, os infinitos simultaneamente sustentam e sảo travejados pelo teor constante. descrito no presente. Os particĺpios reforçam, de modo normal, idêias fundamentais da frase, a começar, e principalmente, pelo termo que encabeça o Capíulo: "Dentre os seres", Tōn óntón, cuja força e importância encadeiam as significaçōes de todo o conjunto.

A que conclusōes poderfamos chegar, partindo dessa exposição cientflica onde se inscreve o exemplo da casa-edifficio e onde é notável a persistência do presente, cruzado com o perfeito. sem a cesura entre o curso da ação e sua consequeência, tal como no comentário de Aubenque citado no início dessas consideraçőes?

Neste ponto, dois fios precisam ser reunidos. Cabe lembrar, de um lado, que a flexāo verbal constitui, no grego, um instrumento afinado para tornar a linguagem acurada at $\hat{\ell}$ a sutileza $a^{(37)}$. Certamente, a prosa de Aristóteles nāo favorece o paralelo corn filosolos e oradores "artistas", que jogam com a originalidade na construçăo gramatical, atentos à ordem e à morfologia das palavras, às suas ressonâncias, coloridos, polissemias e sonondades, voltados para a invenção. Muito pelo contrário, Aristóteles afasta-se deliberadamente desses recursos poéticos individualizadores, para eleger uma escrita cientffica neutra, clara, distinta.

De outro lado, não se pode esquecer que a reiterada reflexão de Aristóteles sobre a linguagem tem sido objelo de controvertidas interpretaçōes, como já tivemos oportunidade de assinalar. Contudo, a tendência para submeter o literário ao logico e ao metaflsico mostra-se predominante. Este acento liga-se à ampliaçăo absoluta de certas premissas e métodos de Aristóteles, sendo discem/veis dois focos irradiadores de tais posiçőes: o procedimento de distinguir, no limiar de todo debate, os vários sentidos comportados pelos termos em jogo, conduta cujo horizonte é "o ser significa" (como em Metafisica $\Delta$ ); a incorporaçāo desse método à dialética, conjugando-a à doutrina das Categorias (como em Tópicos, 1, 9), campo onde é esmiuçada a pluralidade dos aspectos simultâneos atribuídos aos entes. Desse ânguio "a problemática da significação toma consistência apenas quando submetida à problemática do ser. Levando essa perspectiva ao limite, serlamos tentados a dizer que em Aristóteles as palavras só têm sentido quando referidas à problemática categorial e às estruturas lógico-ontológicas que ela supōe. Generalização esta que, nảo sem temeridade, é sempre assumida pela maioria dos intérpretes, mesmo quando tratam de domfnios que escapam a uma análise categoriar".

Coloubaritsis, autor destes reparos, propōe a pertinência de outros princlpios unificadores de processos narrativos e cientficos, que nos permitem discernir "a extensão do legómenon na ordem do que é significante sem contudo vincular-se ao ser", vendo que "mesmo a proposito daquilo que é, a unidade năo se reduz a enunciados de tipo categorial, mas a um texto onde se enredam vários tipos de discursos, inclusive a ficçăo, e cuja unidade, apenas de modo muito amplo, respeita uma certa referência àquilo que ên(38).

Retomando a questâo proposta: os trechos de Aristóteles acima vistos escapam à equivalência do tempo, por ele mesmo estabelecida, na ordem fisica e no sistema verbal, inclusive na distinçâo entre presente e perterto fusionada à diferença entre movimento (kínēsis) e ato (enér. geia $)^{(39)}$. Passagem controvertida, a que voltaremos. Por ora, basta notar que o foco de nosso interesse, a casa-edificio, torna à baila: sua construçāo caracteriza-se como um movimento incompleto (atelês) orientado para fins exteriores. "Nảo se pode, com efeito, construir e ter construldo $(\ldots)^{m(40)}$. Neste entrecho, de modo explícito, o corte entre movimento e repouso no plano fenomênico corresponde à cesura nas formas verbais, entre presente e perfeito.

Conforme tais parâmetros, a casa enquanto érgon constitui uma pausa, onde o movimento se aquieta ${ }^{(41)}$. Al, linguagern e mundo efetivo têm a mesma fonte doadora de sentido. Isto poderia rapidamente nos encaminhar para o alvo que visamos, descortinando o espaço próprio e permanente, a base sólida para a casa-famnia. Năo obstante, o resulfado percluso nos vinculos entre figuras gramaticais e conceitos metafísicos nåo se traduz na trama efetiva do discurso, nos nexos textualmente desenvolvidos entre pensamento e linguagem. Na Fisica, a casa, artefato que é. não carrega consigo princípios de mudança, sendo, por definiçăo, acabada. Nessa medida, losse a "linguagem rellexo fiel da realidade" (como se chega a dizer, por conta de Aristóteles), seria de esperar que ela surgisse evocada por um tempo retrospectivo ou pelo menos indicador de um
Isto o para set entendido da maneira mais itteral: a cealidade se produz novamente Dor meio da linguagom. novamento dor movo da linguagem. Nisio reside sev "poder sundador". de onde prơbem a lorça Imaginativa conceitual. Op. cit. loc. cit., p. 25

24 "Categories de pensere et categoties de langue", in E. Benveniste. op. cit., p. 70.

25 E. Benveniste, op, cit. loc, ett, p. 70. As conclusbes desse artigo visam ampliat-se para alom do caso examt nado. De fato. elas se enunciam com a ressalva: Tanto quanto as calogorias de Aristoteles sejam reconhect. das como validas pata o ponsumpento. cevelam-se como transposicso dos cavelamise comp irangosics categorias do ingua . Embora o alcance goral desse estudo possa se: controverso (nAo palas razbes de Aubenque, mas pelo "derscosido" pa. radigma em que se apoia), as teses Itmitadas A construçao da tabua aris. tolálica continuam pertinentes.

$26 \mathrm{HA}$ quem nAo contoste a aliança entre reflexâ hitosofica o sonso comum cristalizado $\mathrm{na}$ linguagem corrente. J.L. Ackrill, contiante na conciliaçáo ontre pensamento, palavtas e coisas entre pensamento. palavras e coisas problema ou a sua longa historia, afirma: "Em geral. Aristoteles deu por seguro. sem mats, que o uso lingüls. tico as hábitos to pensamontos gregos rafietem a realidade objetivo Je um modo exato a linal. Por cons de um modo exato e final. Pot conse. guinte, o que Alstololes levou a ca. bo, tol uma brithanto ansliso do como o mundo aparecia para um grogo (tat. vez. inclusive, para um europeu ocidenta 1); laltous-lhe, porem, reconhe. cer, em corto grau, que alguém nutrido por lenomenos bastante diterentes poria poderin ter luma visato por completo distinin. Talvez isto oguivatha que Aristoleles Aristoteles o nao Kant". J.L. Ackrill, La flilosofia de Artstotoles. Caracas, Avila, 1984, p. 61.

Tomada isoladamento, ossn afirma. ço - Aristoteles atêm-se ao particu.

lat - poderta assemethar-se à de Benvenisto. acima apresentada. Mas clas divorgem na Intogra: oneuanto as posiços desie ôllimo trazem. im. as posiçoes desie óltimo trazem. imreflexto critica sobre a Doutrina aristotélica, as de Ackrill, valorizando - noxo imediato ontro lllosofia o Ifn. gua natutal, relativizam os "pontos de vigta" e historicizam as teses fllosofi. cas.

As assertivas sumdrias tace ao pro. blema da linguagem em Aristbieles. respondem as proprias fathas de Ackrill no trato como discurso antigo. dando ensejo as incisivas objecoes de ÖBrien lerros de traduçao, contextos enviezados, abusos do idioms itconicel contra sua leitura des Cato. locnlco) - contra sua leitura das Cato. gorlas: .... O necossario ostar atento aos problemas textuais, filologicos o aos conceitos: caso contrário. arris. ca-so a ressaltat om Aitistotolos um pensamento desossado e sem travelamento - breve, urn pensamento destitukdo de interesse real, lanto pa ra a filosolia como para a historia de filosofia". Esta conclus do s ianto mais llosoliac Esta conclusio o ianto mais significaliva, que a tho condutot de ctifica de Obrien a Ackrito sua "ion. dencia para privilegiar a importancia lilosofica do uma obra om rolaçao aon problernas fillologicos a de historia". Desta perspectiva, aponta o que ha de mais llogice em sou motodo: gundo gundo ole, o que ovidente para um nomem do Unnersidade de Oxtord, deveria se lamberm para Aristoleles". Com a lembrança dos editores que retazem os textos a propria maneira, $O{ }^{\prime} B$ rien ajunia: "Ackrill mostra-se mais avan- 
Sado, ele nao tom nocessidado. com etento, de teeditat o terto de sou au. tor quando a traducsio nato the $A$ su. incionte para o romanejamento dos licionte para o romanejamento dos
delalhes, coloca om nota o que o autor 'desejou dizer', embora niso o tonna escrito". Cl. D. O'Brion, "Atris 10te: quantits ef contrariete, une $\mathrm{Ct}$. tique de recole soltor in $P$ Aubengue (edit Concepts at calogoties dans ries Vin, 1980, DD, 97.98,

27 Motatlska, 2. Vil. Piests caloote passagem sso esmiuçados orem Dases da medicina da aite do plos da medicina e da arto de concebida como quriditas de ca da coisa - sua substancia primeita - 1032b 1.3) esta contida na aima oo artista. A genese. que supso a manoncia da torma, en. ceria a meseno movimento no pla. no natual altotico animuis. no natis al allisto: an "assm regotais sad gorados bela "assim chamada natureza lomar. espe cificamente identics. de modo que - homem onpendia o homem (1032a 26): om contormidade, "de corto modo a saude provbm di saudde, casa da casa, o que term matbria to que nio o tem (pots a medicina atte de construif sao bema da saode o da cass. $1032 \mathrm{D}$ 12-15). Noste quadro, as produçbes da natureza pođem se esciarecidas petas da arte. "pois eatas mostram do modo mais claro - que se passa nas getaçoes na turais. C1. B. Dumoulin, Anatyse

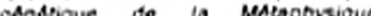
Jarismo Paris. Belles Lemios. 1986, D. 216. Igualar os oxom plos da medicina - que envolvem processos naturais - a da arqui lefura - restritos acos artelact. is implica cetto transito. na. sem pelcalços, entre essas dus anteras: 0 ponto de partiog no contanea pontanea a o callor no coldo. "parte da sadode, tal como as no dras, da casa* (1092b 20-30), $H$ tendernnica nots as ditaculdades de anaiogia entre as rolacbe causais calor-saúde o pedras.ca. sa a primeira o tanto matoria avanto chiciante a Alrime s aponas mater nas materiar Ed, Loeb. 1933 ad, lor.

28 E evidente que meus alvos mudam o centro de interesse proptio a essas passagens, deslocando.o do conceito passagens, deslocando.o do conceilo Dala o exemblo desse moco. o caso particular pode sot dostindado numa ospecie de "mictorcopia", ao serem projetados num campo ceduzido. mas com suterencial pecrso, as elemento orpostos do modo mais amplo. Esta localizaça do exemplo $A$ inversa. localizaçao 5 oxemplo n invorsa mento corrolata ao seu entendimento consagtado $" \mathrm{Em}$ Platao um Onico po radioms suliciente para liborar sontido. esta rdoia o retomada ge neralizada Dor Aristor - univarsal a apreondido intulitiva mente na sensaç $\mathrm{o}^{\circ}$. Cl. Goldsch. mide $\mathrm{V}$, Temps physugue of semps mict V. Temps physulue of temps ragique chez
1982, p. 25.

29 F/sica, II, 1, $1920 \quad 27-33$.

30 Lo orobidme de idte chez Nistote, P. Aubengue. Paris, PUF, 1962 D. 440.

$31 \mathrm{Cl}$, Motaflsica, O. 1048D 18.35, onde hínesis e endigeia sdo esciarncidos

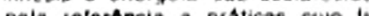
Dala roloroncia a praicas cupo tun b imanente ou oxtanor, represanta das a partit de oposiçoes entro tor mas verbais do prosente e do perter D. Esse terto sor A retomado adiante. A acepcto proptiamenie gramatical do verbo, com o vinculo ontto llexa processo realizado. Assim nảo acontece. Na exposıção da Fisica, as formas gramaticais e as significaçōes dos lenómenos săo orientadas a partir de outro eixo.

Notamos, no decorrer dos parágralos examinados, a persistência de certos signos - grupos verbais dominados pelo presente - e demos relevo a outra marca do sistema temporal, a localizaçáo e encadeamento dos verbos, corn suas determinaçőes precedentes e seguintes. Procuramos, portanto, năo recorrer a um levantamento estatistico desses Indices, mas destacar a rede de suas influências mútuas, de rrc do concreto, no decorrer mesmo das séries consideradas.

A Ireqüència e ordem dessas tormas năo é arbitrária ${ }^{[42]}$. No grego, onde a tessitura dos verbos vem a ser da maior importância, as decorrências dessa concentraçáo de temos e dos significados que trazem ultrapassam o imediatamente enunciado para se propagarem, pelo jogo de suas forças reciprocas, a lodo o conjunto.

O vínculo essencial entre sintaxe e semântica, compreendido de modo amplo (liberadas, a primeira, da simples ordem na trase e, a segunda, das denotaçőes discrelas), levou alguns tebri$\cos$ da linguagem a ampliar esse conceito para objetos mais complexos. Deste ângulo, parâmetros importantes para a abordagem do discurso decorrem da articulaçăo entre signos lingülsticos - como o tempo dos verbos - e calegorias textuais - como o comentário e a narrativa. Há que convir, o procedimento de conjugar sintaxe, semântica e, inclusive, a b́gica peculiar a certos gê. neros nảo é novo, e disto o próprio trabalho de Aristóteles é um testemunho eloqüente. Sua gênese e percurso até nós sena difícil de captar ${ }^{(43)}$.

Retomando um longo fio, essa linha de análise fol tematizada por $\mathrm{H}$. Weinrich, desenvolvendo rellexōes de $\mathrm{K}$. Bühler que, por sua vez, torrou por base o conceito de deixis - ação de mosIrar - elaborada pela gramática grega, renovando-a e inserindo-a no centro de sua teoria da linguagerr. As pesquisas de Weinrich năo insistem no aspecto gestual da deixis, privilegiado por Bühler, voltando-se mais propriamente para a palavra no processo de comunicaçăo(44).

Ora, nenhum desses programas é estranho ao pensamento de Aristóteles. Mostrar mediante signos (he ek tön sēmeiön deixis), reveste-se, na Retórica, de um poder capaz de suplantar a palavra no processo de identificaçăo entre ouvinte e orador. este, ao expressar-se pateticamente, domina o público mesmo "se disser ninharia", razăo pela qual "muitos assombram os cuvintes fazendo ruldos ${ }^{m(45)}$. A Poética também explicita que o pensamento, "parte" da tragédia, se evidencia pelos dizeres dos personagens que "demonstram (apodeiknuasin) algo e manifestam (apophaínontai) um juizo"(46). Ambos os verbos al empregados implicam mostrar, exibir ${ }^{47)}$.

Tais ressalvas năo almejam precaver de anacronismo uma análise de Aristóteles inspirada na referida teoria da linguagem - tolice seria reconhecê-la no pensador grego - mas tăo-scmente garantir a maior congruência de utilizá-la neste caso.

$\mathrm{Na}$ tipotogia elaborada por Weinrich, as exposiçס̄es cientficas incluem-se no "mundo comentado". gênero de discurso onde o presente dos verbos constitui um tempo-chave. Nas gramáicas, inclusive nas de lingua grega, lemos que o presente designa o momento alual e se reporta a latos repetitivos, intemporais, também referindo-se a acontecimentos passados, aproximando-os do leitor ou ouvinte, num processo de "presentificá-tos". Tal afirmação, a que já aludimos ao des. lacar o uso dos verbos na Fisica, pouco intorma sobre a qualıdade do mundo al registrada e sobre o tipo de pensamento que busca apreendè-lo.

Outra abordagem, menos alheia à estrutura e ao movimento do próprio texto mostra-se mais proficua: a hegerronia quase pura dos grupos formados pelo presente, intercalados por raros perleitos, atestam lortes signos comentativos, caracterizando uma "atitude de locução" muito precisa. Se esta regularidade es indicio seguro para línguas modernas, ela não poderia ser mais impositiva aos olhos do leitor, que no referido texto de Aristóteles: nele, o presente nāo corresponde, de modo superficial, a asserçōes imediatas ou reiterativas, nem se refere a este ou aquele ponto cronologico. Indc rrais fundo, ele aparece como a marca de um processo discursivo, conexo à propria reflexăo e ao sentido dos problemas tematizados.

No trabalho concentual e na problemática do texto que focalizarcs na Física, a linguagem cientifica constitui urn elemento intemamente necessário à coalescência do todo sobre o qual opera o pensamento. Deparamos, neste ponto, com uma representaçăo culminante em Aristóteles, graças a qual mesmo as coisas pereciveis podern ser tratadas sub specie aeternitatis, para usarmos a frase espinosana retomada por Kenneth Burke, num contexto proximo ao nosso. Se tivermos por horizonte essas sinteses imanentes, onde "cada parte é em relação às outras e todas as partes são em relaçăo ao todo", estaremos cogitando sobre o mundo artístico e natural "em termos de seu ser, e o ser ê, por definiçăo, um eterno agora". Se assim lor, só pode haver um present tense a despeito das coisas surgirem e passarem with time ${ }^{(48)}$. A temporalidade dos entes escapa à cronologia e é traduzida pela gramatical, com as interpretaçōes que este processo acarreta, inclusive na rede idiomática estabelecida pela sintaxe e pelo léxico ingleses, onde se abre um 
campo semántico impossivel de ser transposto para as línguas latinas, que nåo têm nomes para diferenciar o Tempus.

Esta marca intelectual que, num pun as avessas, explora o próprio meio lingüistico e sua tessitura para garantir os significados conceituais, laz pensar em algumas formulaçōes de Heidegger sobre a "modalidade especificamente grega de apreensão do ser pelo fio condutor do $1 \delta$. gos que, como 'pura presentificaçăo' (reines Gegenwartigen) colne o 'ente propriamente dito' em relaçăo ao presente (Gegen-wart), concebendo-o como ousia, Anwesenheit"(49).

Nesta visada, o ser concebido como presença é solidánio do tempo representado como seqüências de "agora"; a mutabilidade do último condiciona a permanência do primeiro. Para situar. se no tempo "é preciso atravessar a série dos agora; mas para poder atravessá-la é preciso necessariamente ter uma certa constáncia, uma certa estabilidade (...). O agora do ente corresponde de certa maneira ao agora que laz a essência do tempo" ${ }^{2(50)}$. Esta concepção da temporalidade. que onenta a do ser como subsisténcia, é considerada por Heidegger constante em toda a filosofia, mas seu fulcro é Aristóteles, cuja obra "determina de maneira essencial todas as concepçóes ulteriores a respeito'yst).

Lembradas estas interpretaçర̄es de lundo que bafizam minimamente as intrincadas relações entre pensamento e linguagem ${ }^{(52)}$. com referência à concepçăo antiga sobre o ser aprisionado no presente e concebido como permanéncia e constância, voltemos à própria análise do texto de Aristoleles.

A abertura da Fisica testemunha o quanto a linguagem olerece ao mesmo tempo o modelo para ordenar o objeto da ciência e o método para conhecê-lo. "É preciso partir das coisas menos claras por natureza e mais conheciveis. Ora, o que primeiro é, para nós, evidente e claro, são os conjuntos mais misturados; depois, partindo deles e os dividindo, os elementos e princípios tornam-se acessfveis ao conhecimento. Por isto, é preciso ir das coisas gerais às particulares. $O$ todo ế mais conheclvel segundo a sensaçăo, e o geral é uma espécie de todo: ele encerra muitas coisas como se lossem suas partes ${ }^{4(53)}$.

Pelo trecho seguinte, nesta lamosa introduçăo, vê-se que a ordem inscrita na natureza acompanha o agenciamento das palavras: tamberm na definiçăo os nomes indicam inicialmente um todo indiviso que será, depois, dividido segundo os particulares. Phýsis e logos năo se identificam; pelo contrário, o saber da primeira repousa sobre o paradigma e a técnica mostrados pelo segundo. Finalmente, ambos sâo remetidos à percepção e â linguagem originárias: "as crianças primeiro dizem (orosagoreciei) pai a todos os varōes e mãe a todas as mulheres, depois distinguem uns dos outros ${ }^{\text {(54) }}$. Por uma complexa passagem através da lingua determinam-se o problema e os procedimentos para tratá-10, através dela também se techando o circuito natureza-natureza. As análises lúcidas e pacientes do que toi percebido de modo direto e obscuro - as regras do método - seguem, em seus fundamentos, os parâmetros postos pela lala espontânea, de onde emana a classificaçāo. Poderlamos dizer que o pensamento cientffico prolonga, explicita e desenvolve um "estilo" inerente à linguagem primitiva.

No texto de Fisica II que nos ocupa mais de perto, o trabalho da escrita é "aplainar" o concreto, subtraf-lo ao geral, diverso e abstrato, englobado pelo conjunto confuso que aparece no senslvel. Os termos que Aristoteles usa para indicar - no plano da conduta cientifica, 16 gica e infantil - o movimento necessário ao trabalho que deslaz a síntese turva do imediato, remetem à sua teoria do tempo. Nos três casos, as referências a próteron e hýsteron visam isolar o intervalo. o agora que permite a passagem do indeterminado ao preciso, o lapso onde as relaçōes constantes podem ser colhidas. A exposiçåo cientfica une a realidade, igualizando os "tempos" pertinentes aos processos e acontecimentos, reduzindo-os a ordem conferida pelo texto, cujo télos ê apresentar regularidades.

Nesse enquadramento, a textura dos verbos no presente como que "amarra" as outras lormas na cadeia de enunciados, de sorte que cada novo signo, ao ligar-se aos demais, aumenta a conexăo entre eles, resultando num todo sólido e estável. O mundo assim manifesto - uma teia semántica posta num plano nivelado e continuo - fixa a base imprescindivel ao procedimemto classificatório que ponteia e divide essas linhas, nelas estabelecendo identidades e dilerenças. Phýsis e poiésis recortam-se sobre o liso pano de hundo que o texto exibe ao leitor ${ }^{(55)}$. O fluxo dos presentes, constituindo um verdadeiro sistema e desse modo articulando a escrita, pôe em jogo categorias lingülsticas e nåo cronológicas: o princlpio ordenador que unifica e determina o feixe de significaçôes é constituido internamente à linguagem.

Apenas de modo tangencial, quase irrelevante, os preceitos gramaticais concernentes à atualidade e à "presentificaçåo" de acontecimentos passados podenam colaborar para a inteligência do texto e do mundo altamente estílizado (pela propria naturalidade que o Estagirita pretende imprimir à sua linguagem), que ele colhe em suas malhas. Essas tómmulas só poderiam adquirir al- mortolegica o registro remantico, dolineada na Podtica, 20, 1495a 14. 17: O vorbo o uma voz composta significanto. indicando o tompo (.... anda ou tom andado (badtzei - bobddiken) sipnilica ademais o tempo prosonte ou o lompo passado

R. Dupont-Roc e J. Lallot notam, nes se passo, que "sob uma formulaça nemantica - signilicar adernais o tem 00 - una caractorlstica mortolbgica do vertoo a isolada por Autsuleles:

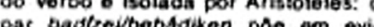
par baclroubebation pon om evidoncia a variaça tormal quo permite so verbo e so a ole. de signiticar seja - prosento, soja o passado (...) Os aulores chamam tamberm a atençbo para a diforença entro esta passagem - Do interpretatione (Capttulo 3), que

aseocia o ponto de vista pranatical -o verbs \& (o nome) que significa odornab o tompo" - e lunça lógica

- "ole o sempte o signo daquilo que dito do outto nome $-1160 \mathrm{~s}-10)$. La Podivue 5 Aristote. tan of noteg. Paris. Seuil, 1980. Nota n* 9 a Capnulo 20, p. 331.

32 Traits compard des langues classi. gues. Ct. A. Maitter o J. Vendryes. Patiz, 11, Champlon, 1969. $p 9$. 224.225. Sogundo osses autores. matices mortologicos e sombinticos tocem a historia do pertoito grego, destaciandora no perfodo que no interessa, aspecto de consenôtincis do processo conctuldo. De acordo do Drocesso concluido. De acordo is no orego mais remoto "o perteito of um prosente que marca o resultado do uma açso acsbada", acepşaso sen strol en remoto e prolongada para alem dole, como no teatro ático, onde - presento perteito encontram so as presonto portolio encontram so as comidos". Expriminde o processo o. mais tro quememente, intransitivo: entretanto "a adiça de um regime tendeu a da no perteito o valor transitivo, isto $\mathrm{e}$. transformatilo num resoltativo, expeiminde que a acho realizada havis produsido un rosultado, sendo este valor caracterfatico do perloito valor caractoristion do perloito opoca ctassica. A lorma do perteito tendia cada vaz mals a tomar o simples valor de um narrativo. isto $\%$. so confundir com o aoristo". Entro tanto "a evolucso loi longa", com a confusao entro aoristo e perteito so se completando no começo da era crists. (9.227)

33 Palerindose nos procedimentos do tivro $\Delta$. na Metaltsica, F. Brentano os compara a exposiçao do gecometra: enquanto esto oltimo "Dor amoc a cla. toza, evita usar expressoos en varios somtidos, Arisolelos vo-se impossior thado (...) do tazet o mesmo. Para is ro. veria de alastat.so demasiado de tingua comum, criar demasiado termos novos o sobrecaftegat demsgia. do a memolia. Procura compensar.

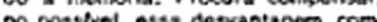
parano parando onlio si varias significacoes exaticaso. uma tente s outr $\mathrm{A}^{\circ}$. Cl. F. Brentano. Arasbieles, Barcelona, La Dor, 1983. p. 41. Noterse tamberm como suas observaches se distanciam das conjecturas de Achrill acima reloridas. Brentano coloca a conduta do

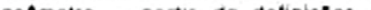
pocmolra parin do dolinikbes guido po Aristoteles. mas do qual se desvia. colhido ontre as oxigencias do vocabulatio cientillico o o uso corrente de ingua.

34 Ct. P. Chantrainne, Dictionnaire dif mologique de la langue grecque. $\mathrm{Pa}$ pis, Klincksieck, 1983, verbete Baino D. 157.

35 Ftaica, I., 1, $10208 \cdot 23$. 
26 Dentre as lormas do piesente contam. se 5 partictpios. \& intenitros o 6 do indrative.

$37 \mathrm{Cl}$, Meitler, A, Apersu Gune Rustout de is langue glecove. Paris, re. chante, 5e e0.. D. 232 to grego notavel pela niticez com que opde a tormas verbalis. Os escritores logam

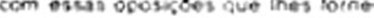
com iom mato de erprestlo". Esse ie. curso \& analanoo por Vestlet en um cassager de Dembiteness esponto

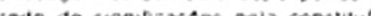
Ja. conchumo trase. onde sparese a pecisso dos grandes es critores. as formas verbar contr. ovem com uma parte incortante des sa exationo

$38 \mathrm{~L}$. Coloubatissis, Tepomenon ef $\mathrm{ka}$ togotoumenon:, in Phisusoghic do language el grammaife dans rant. cute. Bivelat, Outa, 1986, DD. 222.223 e 226 , ressoctivamente, pa

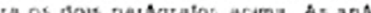

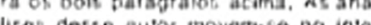
linguagem, mande ancliat os cen tos de teveroncis para a stribukso de inniticasoes a circunsctever or conterus peculiares aus getretos de dircu'r onde tel inciuem. Embora me situe en ingulo divery. was colox.

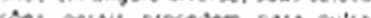

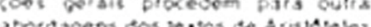

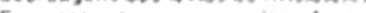
Er contratie com a inclinacto. ne campo hiosotico. para conterit prima. zis ao isgaco e motatheco em doth mento do hiersiro, cate erocal al Daiavill de Peoust teletindo le

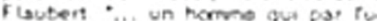

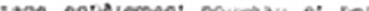

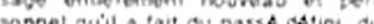
passe indelim, du participe prosent de certains pronons of de corraine prepositions, a tenourele prescue autant note vision que Kant, ave ses Catopories. les theornes de th Connaissance of de la Pealuse ou

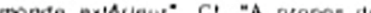
mondo axlorioum. Cl. aropos de "In Conere Sa in Contie Saint-Beuve, ta Pletade, 0 $580(19: 1)$.

39 Metatisica, 0,1048 t 18.35.

40 Metatsica, 6, 1040028.33.

It isto o explectio nas cassagens da $\mathrm{ft}$. exe rederentes so movmento, Com

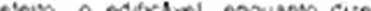

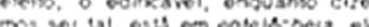

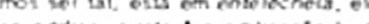
se edinka o ino o a edricarso l...t fisca iil, 201 il 17.19. Mas adunte

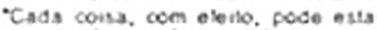
nes alo (energein' ou nsa, toene ediscavet Absum, o alo, ienergeist do editicsivel, enquanto editecarel. a editicacso ou a cases mas quando

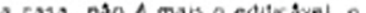
a cava, nalo

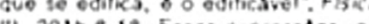
iii. 20108 inims 4 (u minimo cutlosss. So melinot explet. tadas na fica a Nicomaco, $\times, 1174$ $20 \cdot 30$.

42 c'. H. Weinrict, to tempy. Parrs. Squil, 1973. A sucessso des tempor em um tosto obedece manifestada mento a um certo principto de orcem. Sso numerosas essas constelacte temcorais, vertadectas numens ondo se condenam, numa vininnanca ime se condomam, ncma vizinnanca ime tem (1). $100,10.20$ )

43 Um bolo exemplo dessa catica nos otorecido por Proust, no is citado at. tigo notre Flaubert, onde as $10 \mathrm{rmas}$ gramsikan o a suntare so explora. das de modo a doscobut ot aspoctos que inovam a escrita. engendrando sentidos o liaduzindo uma visto ine dita da esistencia, onde "les chose om autant de wie que tits nommes (...). Els inventividade $10 \mathrm{~m}$ Do tonte a "imoressso primeits" recebida guma força se integradas à semântica e à sintaxe do comentâno, a categoria reguladora da escrita propria a temas cientinicos.

É essa a modalidade atravês da qual a linguagem, no campo "epistemołóııco", realiza sua operaçåo defica, mostrando seu objeto e, nesse ato. introduzindo um teor espacializado entre os polos - poeta e público - dessa relação. "O locutor af tem uma atitude tensa, seus propositos tor. nam-se aguçados, pois o que fala o toca de perto e precisa tocar também aquele a quem se dirige. Todos os dous eståo empenhados. Eles agem e reagem. Todo cornentário é um fragmento de açâo: por pouco que seja, ele modifica a situaçăo dos participantes e concerne tanto a um quanto a outro. Compreende-se que as palavras nåo narrativas sejam fundamentalmente perigosas. "i(56)

Se o escritor detemina o modo como seu lexto é recebido, a dimensão estável e contínua, transmitida através dos signos agenciados nos textos da Física mediante critérios intralingûlsticos, ultrapassa muito a quietude que poderia ser atribuida à obra de arte: a solidez da casa é parte da constância, continuidade, firmeza, atribuidas à própna vida e às coisas encaradas na perenidade de sua essência, excluindo o momento, talvez lugidio, do "acidente". Nessa codificaçăo, mundo $\theta$ pensamento tornam-se imobilizados, o tempo é deles excluído. Através da "escrita" logra-se sub. jugar a mutabihdade própria à finitude, paralisando-a de modo "artificioso" e nela imprimindo a solidez propícia ao conhecimento votado à tarela classificaloria.

\section{Discurso metafisico e imobilização da práxis}

Reconstruindo os afastamentos e aproximaçð̌es entre Anstoteles e Platåo, R. Brumbaugh sumanza seus resultados: "A ordem aristotélica da natureza convida à contemplaçáo: ela nâo muda e seus padrőes - as especcies - năo carregam nenhum traço criativo, seja no gerar, lazer ou agir (...) Visto que a ordem se conserva, a análise năo precisa procurar alternativas. Cada parte de um todo orgânico ou quase orgánico é funcional, donde o problema não é se hấ uma fun. ção. mas qual ê essa funçăo (...) Há uma economia estética na forma completa, assegurando que cada ordem funcional tenha um fechamento e um valor máximo para suas partes componen. tes" $*(57)$.

Fixa e determinada, a ordem natural assim concebida pouco espaço abre ao inédito, seja nas obras de arte, seja nas açōes sociais. É deste último aspecto que passaremos a nos ocupar.

Para tanto, será necessáno percorrer o dificil e muito comentado texto da Melafísica, onde Aristóteles começa por distinguir entre movimento e açăo, elegendo télos por criténo: o primeiro nåo chega a efetivar aquilo que visa, a segunda encerra um fim ${ }^{(58)}$. Tal clivagem deixa nitida a diferença ali onde certa contigüidade arriscana turvar as definiçðes. Os dois temos poderiam confun. dir-se num ponto onde eletivamente se aproximam: kinesis é o ato (entelécheia) do que está em potencia enquanto tal e por isto mesmo inacabado, imperterto(s9); práxis relere-se a açbes cujo fi. nalızar nåo constitui um resultado exterior, mas o envolve na propria atividade ${ }^{(60)}$. Se o movimento jamais cessa de mover-se. é atēles - consumado, se auto-suprimina - a ação por sua vez náo constitui um télos - se losse, tambem se cancelaria - mas o inclui, de modo inerente, dentro de si mesma. Nenhum dos dois processos termina em akgo destacado, perfilando-se, ambos, num autodesenrolar. A ausència de fim, no movimento, e a especificidade de sua presença na práxis. propıcıam a vizinhança e requerem a distinção.

Vejamos o texto mais de perto. As açờes que têm um limite săo ditas peri tó télos, relativas a um lim, meios para ele ${ }^{(61)}$. Por exemplo, o emagrecer (to ischnainein): enquanto se emagrece (hótan ischnainêi), as mediaçōes do processo nâo sâo portadoras (mé hupárchonta) "do porquê" do movimento. Em contraste a práxis inclui (enupárchet) o fim a que se orienta. Aristoleles ilustra esta açåo opondo tormas verbais no presente e no perteito: ao mesmo tempo (háma) (ele) vê e tern visto (heórake), compreende e tem compreendido (pophrónëke), pensa e tem pensado (ne.

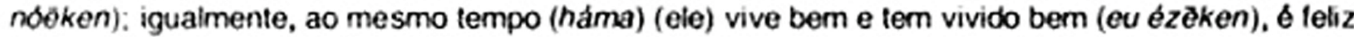
e tern sido feliz (eudaimóneken). Nenhuma fissura aparece entre o enunciado atual e o retrospectivo ${ }^{162 !}$.

Se assim năo tosse, devena haver alguma vez (poté) uma pausa nessas atividades, tal co. mo ocorre quando se emagrece (hótan ischnaínei). Entretanto, agora (nûn) tais açőes nâo cessaram. (Ele) vive e tem vivioo(63). O primeiro desses processos é chamado de movimento (kinēsis); os segundos, de ato (enérgeia). Todo movimento é incompleto (atê̄es): ao mesmo tempo (háma) (ele) năo anda e tem andado, constrói e tem construldo (...). Mas, insiste Aristóteles, (ele) ao mesmo tempo (háma) vê e tem visto, pensa e tem pensado ${ }^{(\omega)}$.

Diante dessas formulaçőes coloca-se novamente, como seria previslvel, o problema dos 
vínculos entre pensamento e linguagem. Aristoteles estaria, prisioneiro de seu idioma, "apenas" tematizando sua experiência nesse plano e transpondo-a para a metallsica? O debate es aceso e dele vamos reler apenas alguns aspectos.

Uma sondagem recente nessa intrincada silva ${ }^{(65)}$ pode nos encaminhar. R. Brague prop̋̋e uma solução de compromisso: é posslvel anuir que Anstóteles tire partido da existência, no grego. de um perfeito corn sentido de presente, mas náo aceitar que ele derive au $\mathrm{fll}$ de um lato lingüisti$\mathrm{co}^{(06)}$. Assim propostos, esses termos săo inquestionáveis. Torna-se menos lâcil endossá-los, potêm, a partir das proprias justificativas aventadas pelo autor.

Examinando o modo como se apresentam, no grego, os verbos utilizados nos exemplos. parece a Brague que Aristóteles, longe de abandonar-se a linguagem, desviou-se de seus padróes para dar-Ihe o feitio condizente com os seus propositos. Algumas daquelas formas verbais teriam mesmo sido "torjadas" pelo filósoto com vista à sua demonstraçăo.

Uma primeira discordância ocorre: R. Brague aborda os verbos de modo "absoluto", tomando as categonas gramaticaıs por sı mesmas, abstratamente consideradas lace às estruluras da lingua ou ao seu agenciamento no texto aristotélico. Entrelanto, mais produlivo que isolar, de maneira discreta, as marcas de delerminados grupos verbaıs, é apreendẻ-las artıculadas a outros, constituldos num movimento reciproco. No texto de Anstóteles a ambigüidade dos perteitos ressalta em plena luz justo porque confrontados com os presentes - num cotejo entre os dois con. juntos de exemplos - permitindo ou nåo sublinhar seu aspecto simultaneamente atual e retrospectivo.

Outra dificuldade também logo acode: năo ê pacfico distinguir em Aristôteles a cunhagem de novas expressōes para se lazer compreendido, dadas as suas desconfianças nas palavras inusuais ou inventadas. Considerando-as obscuras e mesmo destituídas de sentido, ele as rejeita explicitamente na Retórica e nas obras lógicas ${ }^{(67)}$.

R. Brague inicia seu comentário assinalando a mesma oposiçāo entre os relendos tempos verbais nas Refutaçóes solisticas. Numa hipotética, mas verossímil, reconstituiçáo histórica, esse autor supße que Aristoteles possa estar, com a ambivalência do perteito, voltando contra os sofistas as suas próprias armas. Nesse caso, o cotejo presente-perfeito, e as ressonáncias equivocas deste úlimo seriam correntes na época, um "pâo abençoado" para aqueles artificiosos oradores. E de fato, se eletivamente Aristóteles usou dessa astúcia, por que o laria a menos que estivesse difundida e representasse ameaça? Caso contrário, por que atacá-los nesse campo? Por ora, aceitemos isto.

Após discutir outros pontos, argumentando contra o "mero" deslocamento da linguagem para a metalísica, o autor conclui que os exemplos escolhidos por Anstóteles não confirmam "a suspeita de uma importaçåo ingênua de categonas gramaticais para o pensamento fílosofico". Trans. ferência ingènua ou "sofisticada", como o próprio autor sugere, nåo é a queståo principal. Mais ponderável ê centa inconsistência nos argumentos para afimar que Aristóteles ultrapassou ou transgrediu o idioma de sua época, trabalhando-o de modo a "fazè-lo dizer o que ele continha, na melhor das hipóteses, apenas em lineamentos, e para tomá-1o, se necessário, no arrepio". (p. 465)

O problema concerne à própria historia do perteito grego, evocada pelo autor. A citaçăo fazse necessária: "Nos gregos da época clássica, e com mais forte razăo em Aristóteles, no limiar da era helenística, o uso do perteito nos poemas hornéricos deveria despertar certa perplexidade. Esles contêm, com efeito, numerosas ocorréncias do perfeilo de tipo antigo, situado no presente e intransitivo. A história do perteito grego e em grande parte a da passagem desta forma para um perteito resultativo, que exprime o passado. Essa evoluçăo é rápida e, na época clássica, o perleito tornou-se quase inteiramente um tempo do passado (...) As ocorrências onde o perteito tem um sentido de presente deveriam, portanto, revestir-se aos olhos de um grego clássico, de um aspecto estranho". (p. 463)

O contexto dessa assertiva reporta-se à equivocidade do perfeito, ao arcaísmo dessa ambivalência que, reanimada pelo sofista, bem poderia ser um subtertúgio por ele convertido em moeda corrente. Ora, isto vai contra o motivo pelo qual o declínio do perfeito conotando um presente é invocado para afirmar que, usando-o nesses moldes. Aristoteles năo estaria indo rio abaixo, mas remando contra a corrente. Juntados esses dois fios do argumento, ele se rompe internamente. Ademais, mesmo admitindo que o Estagirita tenha "inventado" os perfeitos que usa, o argumento seria irrelevante para sustentar que, na época clássica, tal emprego contranava o idioma normal. Como se verá adiante, justo o contrário parece methor fundado, por várias e complexas razóes.

Essas ınstâncias abrem duas alternatıvas: ou há inflexỏes arcaizantes no discurso de Ans. tóteles - o que sena contrário à letra de sua escrita e doutrina geral da linguagem - ${ }^{(6,8)} \mathrm{e}$, mesmo nesse caso, ele nảo estana explorando a língua no arrepio de seu uso, mas empregando lómulas soffsticas difundidas; ou a oposiçăo entre presente e perfeito era vigente na estrulura dos verbos.
Deto othar do artista, anterior ao 1aclocinio predicativo do causalidacos oxteriores. A narrativa, at, o toda -taite d'imparlaits", indicadores de estados que se prolongam, apenas intertompidos por aiguns pertentos particloios presentes, cujos matizos tecobern grance atercso. O essencos c aue os imperteitos. intensamente

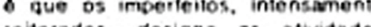
tentorados designa as atividades tanto de coisas como de anmab. apticando-se aos mulitiotion signos dess3s rozes e comportamentos " $\mathrm{F}_{1}$ celle vatisic des verties gagne les hommes qui dans cefle viswon cont: nue, homogone, ne sont pas plus que les choses, mais pas moins, wno ollu. sion a dectire:-

Coisas, animats, homons, recobem ostatuto identico na trama das rola. ostatuto identico na trama das rela. cho do comancista: podemon. nosso passo, reconhecer Flauboll destin. dando a mesmice das existoncias na Education sentimentale, ou em Mun Bovary, ou andas, arremento ua Pa o cincre absoluto em Bourard of Pecuchiot. a mundo sonshor. come aparece para o escritor. om sua imodiatez, ds accsso acs mais profundor nexos da reatidado. tal como a per. cebe. Donde, or vatrios sentictos discernfiveis no julzo de Proust sobere cominincia dos tempos vertanis a

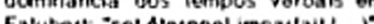

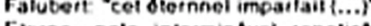
Everno, Dela interminavel repotics no tocto. mas sobretudo etorno por que esso escrits descobre a umedis tez vista pelo artista. desmelando o universo por ele concetido. Universo onde os setes, inclusive os humanos.

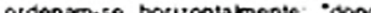
ordenam-se horizontamente: "donc.

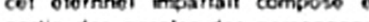
partilit des paroles des personnages que Flaube"t tappotte hatuluellemen en stylo inditect pout qu'olles se contondent avec le resto". Etorno. om suma, porque recobre a inlindavel e monsiona repetiçáo que constitui limise do mundo organico: coisas, animais. homens.

Coniugando Ieoria oa amo analr. Conjugando leoria da afto o analise
da itngua. Proust poe em ovidoncia a da Itngus. Proust póe em ovidencia a
osctita a o campo semsntico inaugu. oscrita o o campo semdntico inaugude suas concepsós sobre o mundo apreendendo a chave estilfstica do reiterado uso do impertento om sov prosalsmo. -donc cet mpartait, al

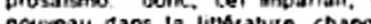
nculeav da ins des otres. comme font une lampe guton a ofolacte. ratrinbe dans une maison nourelle. Pancionne si elle ost presque vide el quion est on plein dombnagemam. Cesi ce genre do tirtesse, fait de la rupture des habu. ludes et de rinsaline du occos ave dudes ei de rine donno le siyke de Flauteer. co siyle 31 nouveav quand a no sorvail que pat 13. Cel impartait seit a repporter non soulement les parotes mais toute la vio dos gens". C1. M. Prount, Essass et afticles. "A piopos du 'style' de Flauber", in Contte Saint-Beuve, La Ploiade, Patis, Gallimato, 1975.

440 ponto de partida de Waintich. na obra de Búhler, ó sua Sorachtheorie. com suas relerencias a Appolonius Dyscolus, gramatico grego do sculo II d.C. C1. H. Weintich, Op. Cit., p. 11 d. 29.

45 Retorica, III, 7. 24-25.

46 Pofica. V. 1450a 6.7.

47 Ao reconstruir o sentido de dae. Benreniste arode a lormxso desse lermo a partir da taiz "dest, apeon. mando o latim oico. Oizer. o o grego defrnumi, mostrar, ma is peecisamente -mostrar por meio da palavia". No ta. timostrar por meio da palavia". No ta. lavra roloridos ao Ambito judicial. Procedimentos comparativos con. 
fluem para liga" "din "ao tato do mostrat mediante a palavra e com autort.

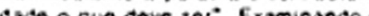
ctiebre ave avo sor. Eraminanco celobie iento soore Eraminanos de Aquiles na lifads. Benreniste conclu que "os termos da eiveessso tome" ca alestam a mosma constivcac on grego e em talun tomos dacen eupein. dizel a drae, como om latim accere. Vé-se corno essa 'demonstracto' ter. mina em um alo de palavis no gre go. O sutstantivo ond rocoire a um

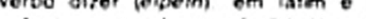
proprio verbo 'mostrar" lofeih) que desizza para o sontido de dizo $r^{\circ}$. $\mathrm{Cl}$. E. Benveniste, Vocabulario de las instituciones indoeuroperias, op. cit. pp. 200.202.

As argumentacoes 00 susor visam es. ctarecer o ientico ingtivucional de te como repiesen mitiat, mas os tesultados que oetbm. inciusive o tonte traço de autoridace. nzo sem conroguóncias para o vato da deters no plano da linguagem, apontando pats o podet subiacente ao campo to percepsto once os gestas "demonetrativos" $10 \mathrm{~m}$ lugar. Para apophsinesthai, ef, adiante.

$48 \mathrm{Cl}, \mathrm{K}$. Burke, "The problem of the inIrinsic. In E. Olson (ed.), Aristotie's poetics and Englisn whorature. Chica. go Un. Piess, 1965, 0. 123.

49 As expressoes sao de J.F. Courtine em "Nole complomentairs pous this. toire du vocabulaire de raire: les tia. ductions latines fousha ef la compes. ductions latines fousta of la compre. in P. Aubenque. Concepes ot castgotes dans ia penste antique Patrs. Vin, 1980, B. 34.

so Hendegget of Platon. A, Boutot, Pa. IIs, PUF, 1987, D. 66.

51 LEtre el ie temes, M. Merdegger. Pa. cis, Gallims.0. 1964. 5, 43 (SuZ. p. 26).

52 Para uma sIntese e apiesonlaçao das tunhas fundamentais doste problema. com suas variantes, no ollimo soculo.

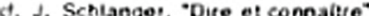

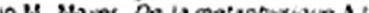
inetorique. Un. de Bturettes. 1986. PQ. 95.102.

53 Para uma lentura go ponso de vista da linguagem. Sesse terto de untos avatares no pensumento moderno. d L. Coloutainsn, regomenon of Ka. tegouroumonon". OD. cit. D. 227. Ft sica, 1, 1, 194a 18-26.

54 F/sica I, 184 a 26, 184014.

5s Para uma andise percuciente dos pontos de contato o alastamento on Ire phisis o polesis, ct, R. Mckeon, - Rhetoric and roetic in the philosoph at Aristolle". in E, Otoon. Aristollo's Angirsh fiterature. Os. st.. PD. 201-235.

$56 \mathrm{Ct}, \mathrm{H}$. Weitxch, Le temes, oo, eit, $\mathrm{P}$ 33. Tatvez convenha lembrar ave es. 33. Talvez conventha lemblat que es. as leses "peitormativas" centuadas em torno de J.L. Austin. C!. pot oremplo. deste autor. Quand dire. ciest tairo. Paris, Sevil, 1270.

Pata as diterencas tace a essa linha. c. as distincoes propostas pol $K$.

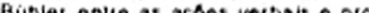
culos ingorsticos a pantir das catego rias aristotolicas do theorta, prifus . notesis. Cl. K. Bunler. Teorsa de lenguaio. Madide. Revista de OCi denle, 1961, Do, 77.83.

57 C. R. Brumbaugh, "It Arstolte had become hoad of the Acacemr in Endigeis. Etudes atistoldiciennes ottertes a Migi. Jannone. Palis, Vrin. 1986, 00, 102.117. (citacces: co. 108.109) em sua flexâo e aspectos, face a outros tempos verbais e, desta feita, Aristóleles, bem de acordo com sua alitude explicita e terminante. em matéria de linguagem, estaria explorando o léxico corrente em seu tempo.

Em abono da afirmaçăo acima, referente as mudanças do perteito no periodo clássico, o autor cita um trabalho de Pierre Chantrainne ${ }^{(69)}$, mencionando também a pesquisa de Meillet e Vendryes, e reconhecendo o teor do perteito homérico no teatro ático. Na verdade, estes autores estendem-no para além, nuançando suas transformaçōes por um longo periodo e localizando sua metamorlose definitiva no inicio do cristianismo ${ }^{(70)}$.

Tampouco o minucioso estudo de Chantrainne autoriza o corte decisivo, aventado por R. Brague. Acompanhemos, em suas amplas linhas, os rumos identificados pelo lingüista. Seu pnmeiro passo ế distınguir, jấ nos textos homêncos, os três tipos de perteitos cuja evoluçăo apresentará: o maıs remoto, com estrito valor de aspecto, desinéncias ativas e intransitivo; um outro. corn desinências médias e sentido passivo: e o mais recente, transitivo e resultativo, ainda novidade. (p. 70)

Estas Iransıçð̋es såo captadas por Chantrainne com extrema flexibilidade, sern passagens abruptas ou unilaterais. Assim, o prmeiro tipo - perterto ativo, de verbos intransitivos, marcando o estado presente de uma açăo passada - é descnto como tomaçăo "ao mesmo tempo arcaica e viva", tanto no ático primevo como no tardio. Enfatizando essa longa persistència, o autor aponta suas mudanças funcionais no sistema de verbos, com a ressalva de que os referidos perteitos "não desaparecem súbita e completamente", surgindo nos escritos da koinē, inteliglveis ainda para os leitores de Plutarco e Luciano. Embora em declínio, sua evolução foi retardada na língua literária, mais conservadora. Pequeno, mas importante número desses perfertos, como gégona, eram vigorosos e correntes na época clássica. Também o idioma lamiliar conservou-os (como egrēgora) durante toda a históna do ático. Multiplicam-se, na exposiçāo de Chantrainne, os exemplos de tais perteitos, attavessando os períodos arcaico e clássico, bem como a koinē, constatados nos textos médicos, históricos, poéticos, trágicos, na comedia, filosofia e oratória. (pp. 71-86)

O ponto nodal na constituição do segundo tipo de perfeifos pode ser apreendido em antigas formas, com desinências ativas em verbos médios, que subsistiram longo ternpo no ático, permanecendo numerosos e bastante empregados. Nessa mudança, o autor mostra como se mantêrn o valor onginário do perfeito no mesmo passo em que aparecem os primeiros casos de resultativos em verbos cujo uso, nos demais tempos, é transitivo. O processo de transformaçáo é gestado no proprio interior do sistema morfológico e semântico preexistente, desenvolvendo-se de modo contínuo. Se na Álica dos séculos IV ou III o perteito ativo tende a desaparecer, conservam-se dele vestígios frequientes, "ruinas" do velho sistema verbal, sobre as quais edificou-se o novo. Os traços antıgos persistem ao serem expostos à diversidade morfológica e semântica da conjugação in fien. Esta linha interpretativa - permanência do padråo antigo, movimentos estruturais sintetizando componentes de estabilidade e mudança paulatina - é reiterada nas reflexőes sobre os outros tipos de perteito.

Voltemos ao ponto destacado por Chantrainne: presença de um perterto ativo numa conjugaçáo média. Seu cancelamento - sua saida de cena - enraiza-se em seu próprio sentido essencıal, ısto é, exprımır o estado presente, resultante de uma açáo anterior. Por causa disto mesmo. tal conotação encontrou seu lugar e realizou-se plenamente no sistema médio-passivo; e por causa disto tamberm, a torma ativa tendeu a desaparecer. Este novo perfeito - com desinências mé. dias e sentido passivo - é. entretanto, visível nos mais recuados textos jônio-álicos, aparecendo vivo e freqüente em Herbdoto. Reconstituindo o jogo de alteraçס̄es, nas formas e conteúdos, Chantrainne evidencia, já em Homero, o valor do perfeito acarretando desinências médias, inovaçăo que se normalizou na prosa jônia. Neste caso, o traço gramatical muda, resguardando-se o sentido consagrado. (p. 88) Processo paralelo ao jónio desenrola-se no perfeito ático: também aí preserva-se o valor de estado presente, com o tema entrando para o campo médio-passivo. (pp. 90-97) Na verdade, todo o sistema se move: as mudanças năo se limitam a "contaminaçăo" do perfeito pelo valor passivo e llexảo média; elas venficam-se também no rumo contrário, com verbos transitivos, ativos, tornando-se, no perteito, intransitivos e com sentido passivo.

Se "o perteito vivo, no século $V$, foi o médio". Chantrainne mostra-se atento aos matizes dessa linha de força. A tendência inclina-se no rumo da figura ativa para a média, mas ocorre sempre, e abundantemente, a superposiçảo dessas formas. Tambêm aqui, é lento o avanço nas linguas literána e olicial, persistindo os modelos tradicionais. Nesse passo, o exemplo longamente comentado pelo autor é gégona, que durante toda a história do ático concorreu com gegénêmai: no decorrer de vários séculos as duas formas subsistiram, sem que nenhum matiz de sentido pareça distingui-las. (p. 110) Nota-se, novamente, que o perteito tendeu a eliminar algumas "ruinas" do sistema indo-europeu, sem jamais consegui-lo completamente. Determinou-se, assim, uma situaçáo paradoxal: o grego manteve por longo tempo o valor semántico do perterto indo-europeu, mas 
expresso por desinências peculiares à conjugação grega em progresso, com o jogo de ativo e passivo impondo-se a todos os tempos ( $\mathrm{pp}$. 117-118). As mudanças, aqui também, abrangem o sistema como um todo: seus rumos $s \delta$ podem ser apreendidos nessa grande estrutura que se move de modo amplo e diferenciado, com suas modificaçōes integradas e paulatinas, que se alteram e conservam.

O último conjunto de avatares prende-se ao modo como o perteito insenu-se na conjugaçāo grega, que tendia a opor uma flexāo média de sentido intransitivo, a uma flexão atıva, de sentido "lactitivo" (como phainomai e phainō). É no bojo dessa tendência que tomam corpo os perfeitos resultativos. A toma envelhecida - sentido de estado correspondendo ao presente - instalada no sistema médio, foi cedendo passo a uma inovaçảo que resgatava as desinéncias do velusto perleito ativo e intransitivo, a ponto destes últimos assumirem sentido resultativo. Esta viravolta encontrava-se já virtualmente contida no grego, pois os perteitos antıgos construlam-se não raro com acusativos, determinando o estado de modo mais preciso: "năo eram resultativos, mas o anunciavam". ( $\rho .121)$ Com o terreno assim preparado, seu desenvolvimento to célere: entrevisto na lingua homérica, multiphicou-se no seculo $\mathrm{V}$, concomitante ao velho sentido de estado. Mas, rertera Chantraınne: o perfeito resultativo, com desınéncias ativas, seguiu paralelo ao perteito intransituvo, médio. "Todo e qualquer verbo permite construir um perterto que pode ou não ser seguido de urn acusativo." Nessas condiçōes, nâo é diff́cil compreender como Arıstóteles, explorando as formas e sentidos do perfeito, não laborou contra a corrente da língua, mas conlormou-se às suas tendéncias básicas. Mormente porque o modelo antigo continuou válido sobreludo nos verbos onde o sentido de estado é sobremaneira importante, como a "operaçăo dos sentidos e da inteligência", caso em que se encontram os perfeitos que Aristobteles faz coincidir com o presente.

Um prisma importante nas análises de Chantrainne define-se aqui: as formas gramaticais têm o seu valor determinado textualmente. Assim, se a lunçăo própria ao perfeito era exprimir o aspecto, o tempo em que transcorre a açăo caracteriza-se em cada discurso. Mesmo o perteito resultativo pode licar arraigado no presente, fiel à definiçăo originária - estado atual de ação passada. Nesses entrechos, a énfase é posta no resultado presente. Questōes de ordem morlolß́gica também pesam: "O perteito resultativo, criado analogicamente a partir do perfeito intransitivo, dele năo se distingue prolundamente, no princípio". (p. 152) A indiferença cronológica do perfeito é considerada por Chantrainne em importante passagem do Parmènides, onde Platão recorre a adverrbios para emprestar-lhes a marca do tempo presente ou passado. Esta ambigüidade, por sua vez, inaugura outra via para o desenvolvimento: a ênfase desloca-se do resultado presente para a açăo passada que o engendrou, aproximando-o do aorisıo. Verifica-se uma clivagem dos sentidos inerentes no perterto.

Sempre acompanhando esses desenlaces imanentes à própria complexidade do tempo verbal, Chantrainne aponta como, de um lado, manteve-se o presente no antigo perfeito intransitivo e, de outro, como definiu-se a sua instabilidade face ao pretérito. Em outra de suas obras, o mesmo autor conclui: o perfeito encontra-se "tiraillé entre o presente e o passado". Simultaneamente distendido em sentıdos contrárıos - por ısto mesmo - o pertento nāo marca uma dicotomia na experiência do tempo, mas certa neutralidade, facultando a associaçāo com o passado e com o presente. E completa: "Aos antigos perfeitos de llexão ativa, de sentido presente e intransitıvo (...) superpōe-se (grifo meu) uma categona nova de perfeitos iransitivos e resultalivos" "«7"'.

A partir desse conteúdo unitário e ao mesmo tempo diverso, diferenciou-se a história do perfeito. Uma vez elaborado o tipo resultativo, o estado presente nele implícito transferiu-se para o objeto e deslocou-se para o passado. A distinçăo entre perteito e aoristo, nos texlos onde se articulam, deixa de ser propriamente gramatical para tornar-se estillstica, aberta ao agenciamento particular do escritor. Se aoristo e perfeito podem expressar a mesma idéia, este último apresenta coloridos cambiantes, diffceis de colher: "cada texto dá lugar à discussão". (p. 167) Nessa linha, Chantrainne examina casos - dos trágicos aos oradores - onde perfeito e aoristo opỏem-se claramente, reiterando a llexibilidade dos usos, os empregos vários e significados fugrdios, a serem apreendidos contextualmente.

Impossivel que esse vasto conjunto mortológico e semântico, com suas malhas gramaticais e teias estilisticas, mexendo-se e clivando-se em camadas que se rearranjam e se superpőem. conservando traços no processo mesmo de sua realização e cancelamento, retroagindo a formas suprimidas para, revitalizando-as, renová-las, seja compativel com o puro e simples corte afirmado por Brague, quanto ao perfeito no periodo clássico. O trabalho de Chantrainne serve mal a tais fins, pelo espirito mesmo de suas análıses, atentas às estruturas da língua, mudando em arranjos onde as partes constitutivas do sistema não desaparecem, não são desiruídas, mas se modificam e se adaptam, recuperando-se em novos agenciamentos. Nem fatıcamente, nem do ponto de vista metodológico, a Historia do perfeito grego serve para justificar uma conjectural perplexidade dos contemporåneos de Aristóteles face ao perteito acoplado ao presente. Quanto mais nåo seja, por-
58 Metarlsna. O, 10486 18-35. Para uma noticia recento sotire a nistoria transmissao go texto, suas diticuka. ges de estabeiecumonto e tradicto ct. A, Brague, Arostote et li, atwestion du monde. Pars, P1H, 1978, D. 545 e sogs.

59 Metar/sica, O, 1048b 21.22. Itsuta III, $211,10-11$

60 Merlaf/sica, 6, 10445, $22 \cdot 24$

6) Melatlsaca. 6, 10480:8-19

62 Metailsica, $0,1048420-26$

63 Metatoseca, 0, $1048626 \cdot 28$

64 Metalsics, 0, 1048 t 28.34

bo Pata as siversas poscoes cissuca soste o astunto, cl, J,P. Partente (od.) Essiars sur le language. Paris. Minuit, 1969.

66 C'. R. Brague, Atistots ef th question ou monde. Paris, Puf, 1986. pD. 453.473. Os números entre paronteses, no corpo do testo, corresponion a Daginas desse volume.

$67 \mathrm{Ct}$, adianie. Por cento, A alributda a Aristoteles a invoncao dos termas entelecheis a enérgeis. Par outro lado, sua recusa em inovar nomenciaturas chepou a loliher os procedi. mentos ciassificalotios om biologia. Esta limitaças, subsctila pot esseciainstas como P. Louis ita decourene do la vie. Atistote. Patrs. Hetmann. 1975. Di 31) A contestada Dor P. Pellegrin i clasvicaston dor anmaur chez anstore. Slatut de la biologie et unite de raristolefirme. Paris, Bellas Lellres, 1982\}, A sou ver, "esta falta de audscia lingüfstica" soria surpreendente em Ariscoleies. visto ele mesmo preconizat a criacso de termos novos quando necessatio. (D. 16) Em nola, apola so om Car? p. 16) Em nola, apola.so om Cat. 7 . exomplo tirado da zoologia. oxomplo tirado da zoologia.

Neses referoncia. importantes elomontos do conlexto om que ela se inscreve ficam obscurecidos. Aristoteles nao cogita de atastar-so do idioma cortonte. mas de supetite alt onde ste no se procutiu, com a $10-$ brice ele niso se procusiv, com a taDaravias o a diresizes palavras e as direlfizes usuais da ilngua. as cortetatiros anchimos iso concebidos - denominados a partir dos primeicos teimos do relaçáso lCat. 7, 7 a 19-24), Inclui-se, nesse ajuste completo dos nomes fabricados a nomenciatura ertabelecida, 0 eremplo

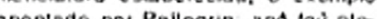
ponndo dou pollogin. apo roù slenu to preroron, oscrevo Atistoteles. Diffcil vor, nesse procedimento "av dacia lingúlstica". O comentátio de Amenonios a esse captluto explica a técnica de produzir tais voc.Abulos" lormar "um nome paronemo a partis tos primeires termos a converter

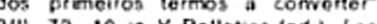
antroutions (Categories). Le loxte aristotdicion of les proldgomdnes d'Ammonios determeias. Patis. Mon. ueal, 1983).

Pouco pertinente of tamborn a citaçAo de Top, 2, 157a 24. Ttata.5e de la. bricar nomes comuns, guando estos bricar nomes comuns. quando estes texto silencis quanto ao modus one. randi. Entrelanto, a induç̧o caracte. riza-se poe sor "mais clara, mais con. vinconte o mais reconhectuol dota sensaçá. comum ao ruljo $0^{\circ}$ (Top. 1. 12. 105 a 16.19\%, Ná o plauslvel que um instrumento moithor duigico para peruaste nogular se constitua com

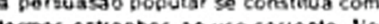
exmos estannos ao uso conteme. No exemplo oforecido na passagem om causa, a donominacto generica tho epistimenos) repete a do particular. Dermanecendo no registo do usual. 
68 Para uma befa reconstituiçso de texto pressupondo a doultina bobre a lin. gungem detenvotvida por Aristbleies na Foblica o no Organon, cl. C. Gavallavolti, "La llessione di nome. vertoo nelta Poetica al Aubtotele". In Endrgera, op, cit., po. 240-248.

690 autor rotere se a risporte du nartait gres, Pans, Chambion, 1927, Os nu meros entie batonteres, no cordo

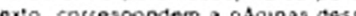
ino

70 Trate de grampane compute des tangues classeques, a, Mollie:, ej. Vondiyes. Patis. Champlon, 1979 Do, 223-227, Voi supra, n, 32 .

71 Morphologie historique du gles. P. Chanlrainne Patis Kincksiece. 1973. pp. 194-t9s.

72 Tricol aprosima este texto de $\Delta z$ 1013 b ', nas oxolicacoes sobre causa linat. A saude $\Delta$ is nou hóneka. concernente as andat (poripatein? assim como a magreza ischnastaj. Os dous eremplos $\$ .10$ associados, nesse contonto, a movimentos, meros para

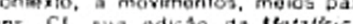
nota 1, ad. bC., Do. 501.502.

73 Para o estatuto do instante a a es cansso oo tombo, ct, V. Gokectrmidl. torws phraque el temps tragnave chez Aristote. Paris, Vin 1982. A diecusaso dotsal questoos atravessa loda a orimeira parte gesto lirro.

74 Essos mosmos termos telornam com insistóncia nas discussoes da F/sica sobre o tompo o o movimento. Cl. entre ourcas passapens, 222a 29 日 222015 . Para uma undise dos at

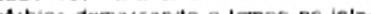
verios dumarando a pampo no inle: ro' do perforto. no Parmentides, de Platao, ct. Chantrainne, Historre du partait groc. DD. $158 \cdot 160$, que amplia posquisa do Merliet. PRovere de Phe. loiogie, XLVUI) que a Metafisica dirne-se a leitores cultuvados: a lingua endita, lembremos, é mais lenta; se o vínculo presente-perferto era inteligivel para os leitores de Plutarco, por que náo o seria para os de Aristóteles? O recurso deste filósolo ao pêndulo presente-perteito prende-se, antes, à sua vigência como conteúdo do pensamento e forma da língua, cuja vitalidade encontrava, para eietivar-se, todo urn complexo gramatical e estilístico. Sem precisar labnicá-los no arrepio da língua, Arıstóteles colheu-os nos caminhos propiciados por seu idioma.

As assertıvas de Brague revelam-se mais vulneráveis quando aproximam o uso do perteito, nessa passagem de Aristóteles, nảo dos pensadores arcaicos ou clássicos - balizas permanentes de sua reflexão - mas da koinē, vizınhança cujo peso năo pode ser avaliado: ainda no juizo de Chantrainne, são demasiado escassas e iragmentárias as informaçōes disponiveis para o periodo alexandrino e romano, visto que os escritores valeram-se da lingua erudita, aticisante.

$O$ estudo de Chantrainne nos coloca num campo diverso do modelo abstrato que exemplificamos com R. Brague. Especialmente quando as formas gramaticais e os campos semanticos se enredarn, o tingüista ınsıste nas ımpliçaçōes textuais, ımprescındiveis para o deslinde dos signitcados. Partındo das própnas ındıcaçőes por ele oterecıdas, podemos constatar que essas diterenças, embora năo se vinculem a normas gramatıcaıs e estejam regidas pelo torneı do estilo, também não são arbitrárias. Não só os sentidos radicais continuam desempenhando certo papel, mas sobreludo o sistema verbal, ele próprio, tende a liberar significaçōes determinadas contextualmente.

Retomemos os exemplos sobre a indiferença cronolbgica do perfeito resultativo, em sua oposiçăo ao aonsto. Chantrainne observa no Laches, de Platāo, uma passagem (178 a) onde um perteito (tethéasthe) mantém o valor de resultado atual: o interlocutor viu (e guarda a lembrança) de um combate. Mais adiante, numa passagem apenas narrativa (grifo meu), onde o escritor nāo deseja maıs insistir num resultado presente, ele serve-se do aoristo" (etheásasthe e theásasthai). (p. 155)

Com eleito, outras observaçōes de Chantrainne recolhem essa abertura do passado no perfeito grego, aproximando-0, em sua função sintática e em seu peso semántico, do presente. No primeiro exemplo do Laches, Platão "emprega o perfetto para designar um ato que serve de ponto de partida para loda a discussāo e cujas conseqüências devem permanecer presentes". As duas funçð̄es - narratıvas e comentativas - que diferenciam o aoristo do perfeito, podem al ser discernudas. Em suas conclusões a esta parte, Chantrainne insiste nessa diferença de valores entre os dois tempos: o aonsto "projeta pura e simplesmente a açăo no passado, ele tem apenas um valor narrativo (gnto meu): no perteito, expressando um estado presente de uma açáo passada, o ato é encarado em suas conseqüèncias". Enquanto o aonsto fecha o passado, o perfeito o abre ao nosso comentárıo.

Propostas essas balizas para o problema, cabe novamente perguntar: que significado assume o perferto, no texto de Arıstóteles, nâo em "absoluto", mas na cadeia efetiva de significantes, an seu fluir?

A primeira marca a ressaltar ê a frequeência dos temos com denotaçăo temporal que pontuam todo o conjunto de frases, aparecendo regularmente diferenciados conforme divergem os processos a que dizem respeito, repetindo-se isto de modo sistemático. Na apresentaçăo do texto, algumas páginas atrâs, tomei o cuidado de lazer consplcua essa incidência e suas conexōes, como o leitor poderá relembrar.

Hótan (quando) associa-se sempre ao movimento; assim também como sua parada relaciona-se com o poté (alguma vez). Năo é de admirar que dimensőes do tempo apareçam explicitamente relacionadas com o movimento e que uma duraçảo seja assinalada por termos correlatos. Note-se, tamberm. que os verbos pertinentes ao movimento encontram-se no infinitivo ou no subjuntivo: hotan ischnainëi - enquanto se emagrece - escreve Aristóteles. A marca do eventual evoca, al, uma perspectiva aberta diante do processo, um lapso que vai de sua origem ao télos sifuado adiante e fora dele.

Supondo-se que o emagrecimento se reporte à medicina: a duraçăo do movimento é determinada pelo ponto em que, eletuadas as prescriçðes médicas, a saúde é atingida ${ }^{(72)}$. Tal como no processo de construçăo, como já foi notado: o movimento dura enquanto persiste o construir e cessa ao completar-se a casa. Com isto, rompe-se a cadeia do tempo: o último "não mais" ocorre num instante sem o proximo "ainda nåo" ${ }^{\text {(173) }}$. Nesses doıs casos - do emagrecer e do construir as relaçóes entre tempo e movimento săo mendianas. O primeiro eletivamente "mede" o segundo. Os advérbios demarcam os verbos com deteminaçōes temporais muito precisas: duraçăo e pau$\mathrm{sa}^{(74)}$

Quando se trata de práxis e de enérgeia, ao contrário, o tempo se contrai; poderfamos dizer que ele se anula. Háma - simultaneamente - elimina o intervalo entre o ver e o ter visto, compreender e ter compreendido, pensar e ter pensado. Al, presente e perfeito fundem-se, a "duraçăo" do 
ato é o instante. Vivernos e ternos vivido bem ao mesmo tempo - háma -. do modo que somos e temos sido felizes. Assim não fosse, necessanamente, alguma vez - polé - a atividade cessaria; tal ocorre quando - hótan - se emagrece. Mas agora, - nün -, nảo houve quebra: vivemos e temos vivido.

Formas gramaticais e conceitos metafísicos determinam-se no interior $\infty$ campo semántico balizado pelos signos e por sua estruluraçăo no texto. Năo apenas os advérbios de lempo assumem essa funçáo, mas o própno vínculo dos tempos verbais, o nexo estabelecido entre o presente e o perteito na caracterizaçáa da enérgeia, é elucidativo do campo de significados textualmente definido. O perfeito nāo poderia assumir, nessa trama, um sentido apenas regressivo, informar sobre o passado. As mesmas categorias lingüisticas, de que já nos valemos, voltam a mostrar-se bem lundadas para esta situaçấo. Nota-se, na montagem do texto, que o perteito, acoplado ao presente, constitui um tempo do "mundo comentado".

O problema, então, deixa de centrar-se no perferto como "presente retrospectivo", ligando uma experiência passada à atualidade (seja porque nela se prolongue ou nela persistam seus re. sultados) para relerir-se aos significados de que se reveste na situaçăo engendrada pelo texto: 0 perfeito nâo relata o passado, mas o comenta ${ }^{(75)}$.

Na práxis e na enérgeia, traduzidas nesse tecido literário, não poderia haver dicotomia na experiéncia do tempo, sendo equivalentes todos os momentos da ação. "(...) Se comentamos um acontecimento passado em vez de contá-lo, é porque ele nåo está perfeitarnente acabado (per. tectum), é porque ele faz parte do meu universo ao mesmo tempo que outros acontecimentos. presentes ou futuros (...) $\dot{E}$ um passado sobre o qual revenho ativamente, pois eu the falo na linguagem mesma de minha açăo.

Exatamente al reside a ambigüidade do perteito, tal como explorada por Aristóteles. Caráter equívoco, que Chantrainne bem captou, realçando a contradiçăo que está no cerne mesmo desse tempo verbal, abrindo o passado, em vez de fechâto.

A desperto de suas tentativas para salvaguardar a originalidade e autonomia filosoficas de Aristoleles face ao universo lingüfstico que o circundou, tomando seu pensamento independente das "meras" palavras, a própria forma e sentido do texto acabaram por inclinar R. Brague rumo a esse vinculo. Seu procedimento fol o de separar analiticamente práxis e télos, correlacionando a primeira ao presente e o segundo ao perfeito para, num último momento, fazer todo o sisterna atividade, metaffsica, linguagem - coincidir. Açăo e fim, presente e perterto unificam-se: o critério do ato é a integração reciproca de práxis e télos. ${ }^{(77)}$

Assim sendo, decorre uma de suas conclusóes: "O ato năo termina de terminar, ele cessa sem cessar. O fim está presente em cada ponto do tempo durante o qual há ato - sem o que serámos obrigados a supô-lo fora do tempo. Eis porque nenhuma duraçáo é designada com anterioridade aos atos, que podem durar indefinidamente (...) O tempo nada faz ao ato, o tempo durante o qual o ato dura não se mede - enquanto ele é aquilo em que o movimento se aproxima de seu lim e. portanto, de seu desaparecimento". (p. 470)

Uma boa expressăo: "O tempo nada faz ao ato". O acento que desejamos dar-the, entretanto, a laz deslizar de seus proprios vetores. Já notamos, no texto ern queståo. de Metalísica $\boldsymbol{\theta}$. as marcas temporais dos signos, distribuldos de modo regular e repetitivo face ao perene - ao mesmo tempo, agora - e ao fugaz - quando, alguma vez. Nesse agenciamento, os próprios verbos assumem conotaçōes que nâo săo propnamente cronológicas, mas pertinentes à "duraçăo" liberada pelo texto. Assim, em vez de esmaecer a "contemporaneidade que sugeriria a traduçáo de háma por ao mesmo tempo", gostarlamos de sublinhá-la, acentuando a sincronia da práxis e abrindo campo à contradiçăo al implícita: năo é alheio ao horizonte aristotélico que o ato esteja fora do tempo.

A vertente teolઠgica dessa noção nos abre caminho. Na leitura de Dumoulin, proposta para essa passagem de Metafísica 0 , a partir de $1048 \mathrm{~b} 18$, a distinçăo fundamental é feita entre movimento e atividade imóvel. Quando contrapóe exercícios cujo fim é exterior ou, pelo contránio, ima. nente - vida, visão, pensamento - Aristóteles tenciona esclarecer "que existe uma atividade está. vel, que nåo é passagem de uma a outra; esta atividade estável ele a denomina, alhures, com a Iórmula leliz enérgeia akinēsias". A expressão registra-se na Ética a Nicómaco, a propósito do prazer constante, impossível para as naturezas compósitas e corruptiveis. "Pois se alguém lives. se uma natureza simples, a mesma atividade (práxis) seria para ele sempre o maior prazer. Eis porque ho theós se regozija eternamente de um único prazer. Pois náo só há atividade de movimento, mas tambêm de imobilidade e há maior prazer no repouso (en erēmiai) que no movimen. 10."

Ato imóvel, próprio ao divino: "para a inteligência da noçăo de enérgeia será preciso renunciar ao contraste entre o dinámico e o estático (...) há uma estabilidade da vida em suas atividades
75 Vislumbramos a ditoronsa ontse 0 Derfeito - como temgo do comentatio - a compo narrativo - que nos atasta de um pastado irtevogavel. no be to exenplo de Proust, lembrade por Weinrich "Savoue que certain emplor de limpartait de Pindicatit - de ce tomps cruel gui nous pessente to

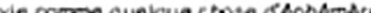

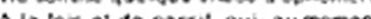
a la tors of ce passe, qui, au mament trappe filtusion, tes andantit dans le passe sant nows laisser, comme to Darfait, ta consolation de ractivite est resté pour mol une source inspui. sable de mystericuses tristesses (Pastiches of molanges) $\mathrm{Cl}$ Contro Saint-Bewve، Ploiade, p, 170.

76 Woinrich lembra: "as IInguas, pelo menos as mais conhecistas, dispoetr tregulentemente de um tempo part. cular oestinado a lornecer uma intor. masso teltospoctiva sobre o passado. macso teltospectiva sobre o passado. Este tempo recotiou, multas vezes, imaginn, denominasso mais inadequada", Neste conter to se inscteve a citaça acma, p. 75. Noutras passe gens. Weintich tambom toraliza a ra guigno das outicacoes tos reopos cuicado das oapheacoes dos rechoos verbais pelas suas denominacoes contingentes, como nas 10 mulas in. leilzes, mas sempre repetidas: Ta coma seu none indka...

77 Seus bosenvolvinentos parexem ins pirar-se nas concepsoes do livro $\boldsymbol{\theta}$. 8 , onde o ato $\delta$ entendido como ante. riot a potoncia - no sentido mais artplo de princlpio do movimento e do tepouso - segundo o tempo e sogun co suber

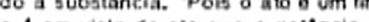
concebicta. Com oleito, nao por possufiem a taculdade de ver que os aninais reem, mas o para ver que eles possuem a taculdade de ver." Este pano de fundo destaca as poni. cles de $R$, flague: $m$ ab (ondtopia). - presente colnciate com o perteito.

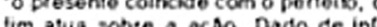
cio, ele abre espaço para a açso que vem recoori-1a. Paratoramento. lim precede a acso vajo porque des. de sempre (...) vi, $\hat{A}$ \&so nso \& como no morimento, apuilo que precede - firn que visa e os qual se aprorim Douco a Douco A acoo sobrevive Seuco a Douco. A dio ainda vejol porque o a partit desse fim que ela se desdobra, porque o fim citcunscreve, com antecedoncia, dominio onde so desenrols a aço, abre um horizonte que precede tod apreensdo parcial. Eis porque tal vez, Ariatorelos oncolhou agut o tor. vez, Ariatotelos oscolinou aqui o tor mo endrgeia. quando se esperari et is question du monde. 09 . at. D. 471.

Entretanso. ndo o era anteriotidade universalizada por Ariatolelos, con. torme se is ao longo do Capfulo of do libro 8 ?

78 Ct. VII, 14. 11540 27. Um dos ale. inentos que mais ampliaram a con cepçà atistotslica, nosto plano. no ocidente. soi a doutrina tomist. Oevs O primuin morons immobile. abso - o primum movons imrabilo. abso lutamente simples. Se a ole aplicam se verbos em distintos tompos, os so inquantum oius aeternitas omnia tom pora includa: non quod ipse variotu por prassons. practoritum et futurum. Imports sublinhar a distinçso ontro 
terato eteindave aeterntas est mensura vastus resse. it taren Wus est propora mensula motes 6. Esse rego terum colluptotium, gurd est transmutasute, non mensuratur aeternitale. Hes tempore. Temevis enim meroural non soluth guar transmutantut in actu, sed guse sun

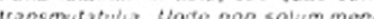

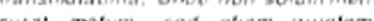
et non mevetur isuma teoldoca, 1 a 10 a.4). Para o comentario do frecho citado of Efica a Nicomaco. ct. Sumb $t$ a. 20 a.t a 3.2 o ben rue Dew? quer 03 a th oon est aliug guarn tose. tul est foct wham essentian conus.

$79 \mathrm{Cl}$. Dutnoulin. Aruyse ofnetigue de

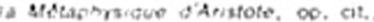
D. 284

80 Poefica, Vili, 1451 a $30 \cdot 35$.

B1 Posifica, 1X, 145b 5. 10.

$82 \mathrm{Cl}, 5, \mathrm{H}, \mathrm{Bu}$, ner, Anstotle's theory of poetry and the art, London, 1902, $p$. 192

83 Poesnca, iv, 1448 b 5-19.

Be Postica, 11, 1448 a 3.6.

85 Postoca, 1, 1448a 3.6. Para a citacto e o comentsio d. Aristote, ta poetr e r. Duport Ploc o J. tallot odu

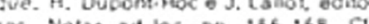
es. ivocis tantom, nota do Capfivio XV. 1454 a 33, Do. 262-263.

86 Portica ix 1652a36.39.

87 Podica, 1X, 1452 a 1.4

60 Podtica, 1X, 1452a 5-7

89 Cl. Chantrainne, Dictionnarte otymo lograve on la lanpur grecaus. OD. cil., sob o verbele dokdo, considera. coen nobre dokdo e reterencua a do kere simultaneamente vis â, apa ência o opiso. para um oxomplo dese acumulo de sentidos. desse acume de sentidos. ch. Comiong. F.M. ac pustalcar ducto a uma dan linhas do Teetero "Pensa, ou julga (dovash), aqui substitul aparece qhathesthal). $O$ que se visa, of o jutio constatanco uma mpressao senther. Plato's theory of

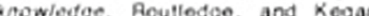
Pant. 1979. p. ?

to c. P. Chantrainne. Oxtionnaire dr mologicue to la langue grecoue. Verbeto Inda, 425 .

Deve-se notar zue theoroin encerra

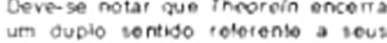
proprios elementos constitutiros. - Eshe verbo, que se tradur multo m. Detertamente nor "comemplar' ef lor. mado oe rida e de norto, que ter uma conotas so stica endente. Int

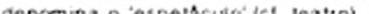

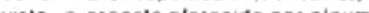
vista, o aspocto olorocido por aiguma corsa e no gual algurna coisa mostr. - que ela e (...) O segundo comco nente de Theoretn, horÁ, quer dizor sumclesmente ve', othar, consudera alguma coisa." Esto comentario di tespeito a and tisen desenvolvidas $\infty$ resoleger. Guas concturoes rosom. mer

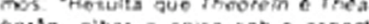
horin, othat a cossa soo 0 aspect Delo qual aparece lerschenti a coisa ptesente. e. pot lat visso, pemane. cer, vendo, perto dela", Em nota autor observa que a decomposis do de meoreir eth tha e hoiso a gerain

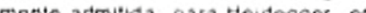

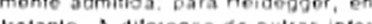

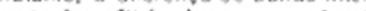
pretaç0os. "théd $\Delta$ menos a ça de ver $\langle\ldots\rangle$, que aquito ave se olerece

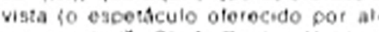
guma coisa)". Cl. A. Boutot, "eideg. ger ef Platon. Paris, PUF, $1 \mathrm{Bg} 7$. D 121.122 o nota 123.

91 Para a importancia dos avatares implicacoos do verbo phalhen, lem. mais elevadas, como a sensf́vel e a intelectual ${ }^{-(79)}$. Por isto mesmo, visăo, vida, felicidade, onde o movimento é elıminado ao máximo, sảo pnvilegiados. Al, pois, em pleno campo da práxis, como no da poiêsıs, destaca-se a preeminência de uma concepçáo estável, constante - no imite imóvel e eterna - que se desenha como paradigmática.

Vista a partir dessa ampla perspectiva, a práxis salvaguarda, em seu proprio transcorrer, uma atıvidade sempre recuperada e homogênea. $O$ que a diferencia do movimento é cancelar a tragmentaçáo própria a este últımo. A poiêsis, ao produzir a obra, opera com a decalagem entre seu início e término, num movimento mensurável pelo tempo: suprime-se exatamente ao se pertazer. Em contraste, a presença continua e serena da práxıs garante-se mediante o esmaecimento da temporalidade interna a seu desenrolar: em sua sıncronia, todos os momentos da ação se equivalem. Defrontamo-nos, pois, com um quadro pacilicador, repousante, capaz de unificar as atuvidades humanas: perceptivas, intelectuais, polficas, éticas, vistas num horizonte teoløgico, onde o negativo do tempo, em linguagem moderna, ou geraçảo e corrupçāo, numa fala menos anacrônica, mas nåo menos prenhe de consequeencias, se minimiza. No plano da Metafísica, o movimento perturbador é abolido da prática humana. Em seu discurso e pensamento dá-se a unificaçåo da práxis, vinculando perteito e presente: elimina-se o tempo, pois não há movimento a medir em atividades concomitantemente sucessivas e simultâneas.

Passemos, agora, a um outro plano da obra de Aristóteles onde se oferecem em conjunto, e concretamente, as reflexđ̆es sobre práxis e poiésis, na Poética.

\section{Polesis e práxis em concreto: a poética pacificadora}

Consideremos brevemente a essência das artes representativas expressa na Pótica, a ımitaçăo. A estrutura unitária e totalizadora da mimessis ${ }^{(80)}$, e sua convergência para o universa ${ }^{(8) !\}}$, já bastanam para afastá-la da reprodução dos fatos empiricos, aleatórios e dispersos. Ela nāo pretende simular réplicas do existente, mas apreender a "forma" de seu modelo, dinamizando as capacidades sensiveis e intelectuais tanto do artista, quanto do público, o que Ihe garante um teor simultaneamente prazeroso e didascálico ${ }^{(82)}$.

Nesse processo, é inerente à mimēsıs, proprio às atividades criadora e receptiva da obra de arte, o reconhecimento da semelhança entre o produto técnico e seu onginal, sendo este olerecido pelos caracteres, atributos passionais ou açőes no plano concreto, assim como pelas expectat:vas generalizadas no público ${ }^{(83)}$. A própria divisão dos "personagens" em apenas dois tipos - nobres e baixos - assenta no pressuposto de que "todos (pántes) diferenciam os caracteres pela nobreza e pela baixeza $\mathrm{a}^{-(84)}$. Nas artes imitativas trata-se "da cópia (eikōn) executada pelo artista, a partir do modelo real ('nos', kath' hēmás, 'os hornens de hoje', tőn nün)", que ele pode transtormar acentuando desvios positiva ou negabvamente marcados, postos no plano ético ou determinados segundo criténos estéticos ${ }^{(85)}$.

O encadeamento de feitos e açóes articula-se, de modo internamente coeso, à sua unidade: o trabalho do poeta é dizer, nảo o transcurso da vida efetiva, mas o que poderia ter lugar "segundo o necessário e o veross mimi" ${ }^{*(86)}$. Determina-se urna depuraçáo nos elementos constitutivos do sistema reproduzido, uma triagem rumo ao universal, processo este que mantém, no plano da copia, o métron de seu modeto natural.

Note-se como o ponto nevrálgico da tragédia, suscitar emoç̋̋es de medo e piedade, não abandona uma dupla referência às coisas tal como săo e tal como construídas. O efeito de surpresa, decisivo para o alvo em mira, chega principalmente atravês de acontecimentos que são "contrários à expectativa comum" (parà tên đóxan), comovendo prolundarnente por surgirem "uns dos outros" (d' álléla $)^{(87)}$. Nesta técnica, o necessáno e o verossímil desenrolarn-se segundo a 10 gica intrínseca à poesia, mas sua torça nutre-se, mesmo no arrepio, da causalidade, princípio que rege o mundo natural.

No espetáculo, tudo ilude. De um lado, a sensibilidade e o discemimento do espectador exposto à torça dramática movem-se no terreno da opiniåo: o evento aleatório, sobrevindo em série causal, parece. đokei, a ele, admirabılissımo, thaumasıotatōn. De outro lado, a poétıca, ındo ao encontro desse resultado, opera no plano da aparéncia: o fortuito será tanto mais admirável quanto maıs aparece, phainetal, engendrado como de proposito ${ }^{(38)}$. llus $\delta$ rio, sım, mas resguardando, justamente para lograr sua intima coerência, uma finalidade semelhante à da ordem exterior.

Esse duplo jogo de ilusbes óticas, entre o parecer ao espectador e o aparecer do enredo. trama-se atraves dos significantes-chaves do texto. A doxa do primeiro envolve todo um comple- 
xo de sentidos que abrange, de uma parte, o que se espera, pensa ou admite, o que parece, no registro do juizo e, de outra, conteúdos relacionados com o visivel - o que aparece no registro do olhar ${ }^{(\theta 9)}$. Thaumásios, admirável, envolve também conteúdos releridos à visão, verificando-se relaçðes semántucas entre theáomai, cujo sentido é "contemplar, com dois matizes acessórios pos. siveis de admiraçăo e de espetáculo que é oferecido" e thaumáz $\bar{O}^{(90)}$. O feixe de significaçōes relatıvo a phainomai ou a phainō. de um lado dispensa comentário, por sua longa e riquíssima tradição especulativa; de outro, por esse motivo mesmo, licaria excessivo tralá-lo neste contexto. Basta lembrar suas ligaçōes com a luz, phōs, donde todo o horizonte de visibilidade - do que aparece - definido à sua volta ${ }^{(91)}$.

O agenciamento das açōes - localizado nas respostas catárticas ampliadas pela referência ao costume e à natureza - coaduna-se ao feitio dos caracteres. Seu primeiro atributo é ser chrěstós, de "boa qualıdade"(92), termo "certamente portador de uma carga moral positiva; entretanto, ele pode ter uma traqueza (ou 'maldade') exigida pela açăo. Assim, o encadeamento dos fatos supőe que o personagem seja suficientemente falivel para ser 'semelhante a nos' e suficientemente bom para que o espectador se apiede de seu infortúnio imerecido"(93). Mais urna vez, nola.se um alastamento na construçăo poética, distância esta que, por si, assinala um ponto de parfida in re.

Nāo por acaso, o caṕtulo sobre os caracteres termina com um simile entre o poeta e os bons "retratistas" (eikonográphoi). Estes, "apresentando a forma própria (tēn idian morphēn). pint2n. retratos semelhantes, mas mais belos ${ }^{\text {"(94) }}$. Phýsis e poiêsis assemelham-se e diferenciam-se. mediados pelo poeta que seleciona o matenal e monta a imagem, e pelo público que a recebe $\mathrm{e}$ confirma, ambos cúmplıces da mesma prestidigitaçâo.

O trabalho seletivo e redutor do artista na sintese do mýthos, compondo um todo unitário e orgánico, aproxima-se, pelo esquematismo, do desenho, puro contomo marcando seu corpo de significaçōes, onde o imediatamente sensível subordina-se à intelecçâo da forma: aplicar as mais belas cores em desordem não resulta no mesmo encanto que desenhar em branco e preto (leuko. graphein) a imagem (eikōn $)^{(95)}$. Lembrança da alva e despojada perfeiçâo platônica?

Com efeito, a estrutura dos argumentos e a tinguagern usada por Aristóteles, na análise das emoçōes trágicas, acercam-se do Sofista. A fim de perseguir este personagem, Platāo penetra nas trocas entre orador e ouvinte. Neste ponto, já é elucidativa a pergunta inicial do Estrangeiro: qual seria o poder mágico, a coisa admirável - thaúma - proporcionada por aquele artista, no sentido de aprestar os jovens para a opinião - doxa - de serem eles os professores mais sábios em tudo ${ }^{(96)}$.

O saber exibido pelo mestre e seu reconhecimento pelo aluno constituem o meio onde opera a magia do mercado: a conversão, dos produtos adulterados olerecidos pelo sofista (os alimentos da alma), em dinheiro, pago pelo enleitiçado jovern que supōe deles necessitar. $O$ deslindamento dessa miragem se faz mediante a intrincada passagem pela aparência e pela parecença em contraposıção ao ser. Se os solistas "nåo discutiam corretamente, nem assim apareciam (ephainonto) aos jovens e se, aparecendo (phainómenoi), nāo pareciam (eđókoun), através das controvérsias, ser prudentes (einai phrónimoi)", o negócio năo se realizana ${ }^{(97)}$. O contraste e o trânsito entre parecer, dokein (com o acúmulo de sentidos da percepçăo e do discemimento), aparecer phainein e ser, einai, projetam em cena a figura dos sofistas: eles parecem (dokousi) conhecedores de ludo. aparecem (phainontai) como sábios a seus alunos, não o sendo (ouk óntes). Nesse lusco-fusco avulta o sofista, com seu cabedal: possuir ciência aparente (đoxastikē) e năo verdadeira, com o disfarce do mestre e o correlato engano dos discipulos ${ }^{(98)}$.

Atravessando a operação do aparecer e do parecer, de um lado efetiva, de outro lalaz, entra-se propriamente no plano da imagem e Platăo, retomando o velho legado que explora vánas vezes, aproxima as figuras verbal e plástica. Produzindo imitaçర̃es homônimas às coisas, as pinturas mostradas "de longe" podem enganar os meninos menores e mais tolos; assim também a retónca pode lasciná-tos, mostrando-lhes imagens faladas (eidōla legómena) de todas as coisas $^{(99)}$. Certo pendor educativo do diâlogo se explicita nas palavras do Estrangeiro, que visa trazer os moços "o mais proximo possivel ${ }^{\mathrm{m}:(00)}$. Ao contráno do filosoto, que destaz ilusठ̄es de ótica, o solista pertence à raça dos prestidigitadores (thaumatopoiol $)^{(101)}$. No âmbito da mimēsis e da do$x a$, ele é parente - por linhagem e sangue - do génos fantástico da arte-de-tazer-imagem, definido como a parte que, nela, $e$ do maravilhoso (to thaumatopoikdn mórion) ${ }^{(102)}$.

É este, rapidamente apresentado, o contexto em que Platăo começa a dividir as artes figurativas. De um lado, há aquelas que mantêm a mesma proporçăo (symmetria) do modelo, na forma extenor e nas cores ${ }^{(103)}$. Aquilo "que é outro (tó héteron), mas semelhante (eikós), pode ser chamado cópia (eikōn)" e a imitaçăo que assim se exerce é produtora de semelhanças, é eikasti$k e^{(104)}$. A diterença desta, as medidas dispares expōem seu pleno eteito enganador nas obras de bre-se. pot exemplo, de seu lugar om tegel, onde a propria dialotica o es peculativa, idcias implkilas nesse tormo elucidam- se num comentaco of tieidegor *Pois sperulat aver to

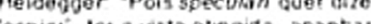
"eapiar, vor a vista a compreonder (begreifent, explicitanco-so, em seguida. que esta aproen sao nso busca apenat a unidade. mas scorétudo captar o oposto". Ta o o reino da antlieste, cuja modalidade soxposta na logica da essóncia ía logica da te fleral Detse jogo de logica da fellondoj. Desse jogo de rofiexos. desse espenamonto. ospe culari (speculum. espelhol receto bu. determinaçăo suficiente". Assim pen saca. a especulacto identica-se dialelica: "o espolnamento do lado oposto o sua relerencia a unidado como o prosesso fo producto do pioprio Esplite". "ias palarras do A proprio Espinis. Bowlor (op. che "o movimento espeonde a movimento peto qual o Absoluta mira. se a si mesmo om si moimo ${ }^{\circ}$. Os co. mentstios de tivideggot terminam ar go desencantados: "imagina.5e que nosso lempo ultrapassou tais extra. vios de eopeculas.jo, Mas vivemos vios de eopeculasao. Mas viremos bem tasmogofa', M. Heidegger, "Hegel er les gress", in Questions II (trad. J. Beautiet e P.P. Savagel. Pans, Puf. 1968, p. 51. Essa teitura de Heidegget deixa na somber as unplicacces viotentas do espethamonto pervetso em Hogel Para a crltica oesso posi Cho, Robero Romano. "Dideror, çao, cf, Roterto Romano, Diderol, Pendiope da Aavoluçä., in Revista USP 1. 1989.

Para um tratamento especfico de questoes ligadas a phalno em Alis. steles, ct. M. Schotield, "Atistotle on the magination ${ }^{\circ}$ in G.E.A. Lloys - G.E. Owen feds.l. Acistolic on mind and the senses. Shoccedings of mind and he sonses. Fhaccecings of U. Cambridge University Press, 1979 pp. 99.149.

92 Postica, XV, 1454 a 16-17.

93 Podica, ed. R. Dupont.Roc e J. Lat lot, nota a XV, 1454a 33, n, 3, pp. 262-263.

94 Poética, XV, 145ab B.10.

95 Postica, VI, 1450a $40-1450 b 3$

Deparamos, aqui. com um patrimonio arcaice, bastante retomado nas cuttu. ras greoa o latina clasucas e, por va. ras groga o latina ciasucas e, por va. hios caminhos. logado no Renasci. menco a Alodernidede. Voja-se. por exemplo. a indicacta de J. Stato binsky sobre o privilegio conterido pot Kant ao desenho "em todas as aftes plasticas (...) 0 essencial of desentio, o que constitut, pata gesto. a condicto findamental nao gesto, a condica tundamentr. atgradavol, mas simplesmente o que agrada por sua torma. As cores que lluminam o desenho perioncem ao atraltivo. elas podom vivificar o objeto em sia para a sensaço. mas nato borna-lo digno de ser contemplado. beto L. (Cinica do julzo, 5 ; 4) Ct, 789 Les comblomes fo la rasson. Paris, Fiamation, 1979. 0 . 195 . Esto o discutido oot Robetto Romano, que oxamina as projoçoes gralicas nas bos Crfticas de Kant. Noto-se tamberm - ponto de intiorso do esquema para a cor nos escrison de Diderot. Para as duas questoes, ct, "Kant o a Aupula - in Coroo o cristal, Mara rom co. Aio. Guanatiara, 1985.

96 Sotista, 233A.B.

97 Sotista, 233A.

98 Sofista, 233C.

99 Sofisti. $234 \mathrm{C}$.

100 Sotista. $235 \mathrm{~A}$ 
10: Sofista, 2358.

102 Solista, 260D

103 Solista, 2350.

104 Sotigta, 236A.

105 Sossts, 235E, 2368.C.

106 Sotista, 238C.

Poetas e pensadores renascentastas gue refletiram sobre a imitacto is fi zeram roferencia ao Sofista, distin. guindo ontio a posia, que deve so casstace. "which same learned have delined, liguring forth good things". a que bhantastac, "wich does convariwise infect the tancy witn unworthy objects". Cl Sir Phillp Sitner. An apology tor poetry. Sicher. An apology tos poet

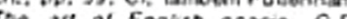
the ant of English poesie. O.D. Willood e A. Walker (1936), PD. $18 \cdot 2$ ?

v. Coldschenidi indica, a partif de C.lunbert. a distinçso grocodida no pertodo heienfatico entre imitac so Covta oltima $C t$ Temps physiguo temps temps trageque chez Anistote. Paris. Vtin, 1982, D. 262, n, 140.

107 Aestrica. 1. 11. 1370a 4.8.

108 Resorica, 1. 11, 1370 a 9.18.

109 Talvez nso seja ocioso tembrat que. no eslebre texto onde a tragetia vetermina se como imitacto da vida. o usado o tormo tos, cujo sentido oesdobtarse nos planos ifsico e dir $\infty$. Na passegen da Aelonca, acima citada, o elemento domesticador of Ba, forga corporal, wolencia fisuca. e fo ethos enptegado neste con torto, corretstamente antsis. Os

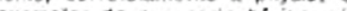
oxemplos do lento, onvolvem smoos esses cam. Dos. nums tensto o ostorço da alm - do corpo: epindteia, spovde. symonla.

Para o Ambito natural dos pathe, in clusive huas implicaços oticas, ver Exea il. 4, 1105 $21-23$, onde tho enumerados, entre outros, medo e piedade. Todos es ses estados afetivos constituem - rentimentos do ptazer ou dor wus citados (ou sentidos) pelo que imagetice prantustai enquanto Diatintas de Aisthenats. perceostes tireta i" sendo gue nos 3nimais superiotes of momem, as "akthe mata persistem e reviven na forma de imagens chantastai, phantss. mata), e estas, tamberm, envolvem brazel ou oor". Ct Ariatotie, the 2 . H.4. Joachima Ortoro. Claren P,H, Joachim, O

110 Pastica, XI, 14526 10.13.

i11 A afiemaço mais torte: VI, 14500 16-20. O espetsculo of aineio $\mathrm{a}$ arto.

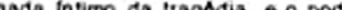
costa atores. Para a montagem da poça a arte dos "conaristas" o mais impor. tante que a do poeta. Em XIV. 14535 1.3 a soparacto se atenua piedace e medo seguramente nas cem tanto do espetculo quanto do apenciamento das acos, mas prod aperciamionto asoos, mas propote a montagem o nac a comocosto da peca.

112 Podica, XV, 145303.6

113 Dumortier aponta somethante trans posiça de sensaços em Esquilo ktioon ddootka, otho o batutho (Sept. 103), assim como outras (Sept. 103), assim como outras tha dos olhos, olhat da maol. C1. J Dumontier, Les imagos dans la por sie dEschyle. Paris, Bolles Lestrer. grande porte, onde a operaçăo imitativa altera as proporçð̄es do belo ${ }^{(105)}$. Aquilo que aparece (tó phainimenôn), atravês de uma visão desfavorável, de modo a assemelhar-se (eoikénai) ao belo. mas que - fosse possivel apreendê-lo adequadamente - "năo seria semelhante (eikoss) ao que dizem assemelhar (eoikénai)", chama-se phantásma. A arte que produz apariçర̋es, mas nåo cópias, é denorninada phantastikē por Platăo(106).

Aristóteles não se encontra, afinal, neste espinhoso assunto, tăo longe de Platåo. No quadro acima delineado, a poesia, tal como ele a concebe, visa produzir uma cópia. Eikōn e formas de eiko săo os termos sistematicamente usados, com uma univocidade de sentidos que nåo se precisa, neste caso, pela referéncia a uma significaçăo corrente, estabelecida por um background psicossocial comum, mas de modo bem determinado, por sua inscriçăo num processo artistico ao mesmo tempo reprodutor e inventivo. $\dot{E}$ este contexto técnico que thes confere sentido e os torna exatos. O estatuto do modelo, evidentemente, é diverso nos dois filosofos, acarretando sérias consequeencias de outros pontos de vista, mas năo no plano dos procedimentos inerentes à elaboraçăo da obra de arte.

Se o mýthos obedece a critérios intemos, constitutivos e unificadores de suas partes, totalizando sua elaboraçāo, o ponto culminante da intriga - as paixōes e seus efeitos catárticos - evidenciam, ao máximo, o quanto a fábula ancora-se na vida, para citar Arisıóteles, apreendendo os arcanos de sua natureza, penetrando seus nexos mais prolundos, transpondo sua ordem para a ficçăo. A poesia incorpora também o estrato mais direto, mais sensivel, onde o habitual se converte no inato: o costume é semelhante (hómoion) â natureza, pois o que é freqüente - o costume - está proximo do que é sempre - a natureza $\mathrm{a}^{(107)}$. A violéncia que se produz "contra a expectativa comum" delineia-se e toma corpo justamente em contraste com a não-violência do hábito, capaz de converter mesmo o que é doloroso, em doce, durável contentamento ${ }^{(108)}$. Por esse caminho, as paixóes se aplacam, amansam no prazer poético ${ }^{(100)}$.

Em suma, a poesia tem por cenário a gênese, a estrutura e o movimento das coisas efetivas: ao mesmo tempo, a imago desprende-se do particular e do individual, alcança autonomia $e$ tende para o saber filosófico - seu pano de fundo es o ser. Cópia, portanto, a mais fidedigna - desenho depurado, nâo cores profusas - nunca a se confundir com a filosolia ou a metafísica. Por outro lado, a própria condição de sua existência como obra de arte representativa do universal de. pende do retomo ao visível, ao "espetáculo", ao jogo de ilusóes óticas do qual vive a cópia.

Se Platăo bane a poesia da esfera da polnica e da educação do estadista, numa crnica dirigida ao estatuto da imagem com as distorçס̄es introduzidas pelo aparente, é por razóes opostas que Aristóteles a exila do discurso que elegeu para o sábio, com a imagem se tornando gradativamente mais mentirosa quanto mais se afasta das formas e conteúdos sensiveis, do patrimônio comum. Vejamos como isto pode ser melhor explicitado.

No Capifulo XI da Pó́tica, o páthos é considerado uma açăo destrutiva e pungente, realizada en tōi phaneröi, termos usualmente traduzidos por "em cena"(110). Esta passagem tem provocado dificuldades, visto que Aristóteles tambèm afirma que o espetáculo năo é intrínseco à tragê. dia $^{(111)}$.

Um elo interessante nessa ordem de idéias acha-se no Capflulo XIV, onde a primazia do mýthos liga-se â sua auto-suficiência: É preciso que, independente do ver (horán), a história seja contada de modo tal que ouvindo os teitos (akocionta tà prágmata), se trema e se lamente pelos acontecimentos" $"(112)$. Aristóteles náo diz "ouvindo os relatos", mas ouvindo os feitos misturando os campos da vista e da fala. A expressăo ê empregada de modo natural, sem segundas intençỏes, podendo ligar-se a usos vetustos ou estenotipados, aspectos que so a tornariam mais elo. qüente ${ }^{(113)}$

Igual contaminação de campos senslveis e semânticos ocorre no capftulo final, onde Aristóteles chama espectador - theatēs - tanto o público da tragédia quanto o da epopéia: "diz-se que esta se dirige a espectadores (pròs theatàs) comedidos, que năo precisam de figuraçőes externas (tön schëmátôn), e a tragédia, aos interiores"(114). Mais à frente, condenando o histrionismo, afirma que a tragédia prescinde do movimento para obter seu eleito próprio: através da leitura sua qualidade torna-se manifesta, evidente - phanerá(115). Vem a proposito, a observaçåo de Chantrainne sobre a ambigūidade semántica dessa familia de palavras, radicalmente ligada a brilhar, esclarecer, e por outro lado, a dizer, explicar: uma lucidez que se mostra simultaneamente no plano da visåo e no registro da voz ${ }^{(16)}$. Espectro a se espalhar sobre as linhas contiguas, onde Aristóteles se reconcilia com a dança, a música e os espetáculos (tàs opseis), partes não-negligenciáveis, que produzem os mais nftidos (enargéstata) prazeres. Finalmente, perfaz todo o circuito: "a tragédia mantém seu brilho (lo enargès) tanto recitada quanto em atos (epi tǒn érgōn) ${ }^{(117)}$.

Com estas indicaçes, toma-se possivel afastar os percalços para o entendimento do pa. thos representado en töi phaneröi: ele năo é posto "em cena", mas posto de maneira clara, ex- 
pressa. As dificuldades se minimizam ao atentarmos para o estatuto recebido, no contexto poético, pela aparência e pela imagem, onde se aloja a palavra, com toda a constelaçáo semântıca e lécnica posta a serviço da pelf́cula ilusóna que se projeta no visivel. Creio que o maior obstáculo à compreensăo dessa passagem vem de nossos próprios quadros e hábitos mentais: pensamos de maneira ou demasiado abstrata, ou demasiado positiva. Afinal, a concepçāo piástica da sensibilidade e da linguagem, protundamente ancorada na cultura grega, atenua a importância do paico empirico para visualizar a imagem, para emitir ou receber seu impacto. Se o texto acima visasse um componente cênıco, no sentido direto, por que não usaria Arisıóleles a palavra própria skēnē?xi18)

Nâo obstante, resta que a composição dramática tem por alvo o teatro que é, efetivamente, um espetáculo coletivo vivido intensamente em momentos culminantes da vida pública. Assim como a retorica, ele é dirigido a ouvintes e espectadores: em ambos os casos o poder das palavras e gestos såo dirigidos e modulados para atingir e mover suas almas, persuadir, lornar crivel. As vánias faces da imagem - sua funçâo mediadora em todo processo perceptivo e sua visibilidade potencial ou em alo - são invocadas por Aristóteles corno critério de avaliaçăo, pelo próprio poeta, da eficácia de seu trabalho.

Todo o Caplulo XVII, onde são desenvolvidos os procedimentos para esta aterição, é dorninado por dispositivos visuais. Para bem compor o poema e polir a expressāo, 0 autor deve colocar para si mesmo diante dos olhos (prò ommátôn tithémenon) o enredo que trama: aquele que vê. (ho horön) como se assistisse às açōes mesmas, descobre, com máxima eficácia, o que é apropriado, sem esquecer nenhuma incoerência ${ }^{(19)}$. Com este recurso, o artista traz, para dentro de seu proprio trabalho, a carga sensivel das figuras que gera. Seu olhar, fitando as ações no momento em que as preludia, mimetiza sua atualização, inserindo-as no movimento que as engendra; conchuindo a réplica, simula a vista do espectador que receberá a imagem acabada, o produto da arte final. É a acuidade do poeta que afina o critério de sua arte. ${ }^{\text {") }}$

Este forte vinculo entre imagem e processo intelectual na invençāo artística tem, como contrapartida necessána, o espectador (tòn theatén), seu othar que recolhe as aparẽncias. Nảo tosse isto, diz Aristóteles, referindo-se aos insucessos de certa obra, se os espectadores não os tivessem visto (mễ horônt'àn) poderiam passar desapercebidos; mas, em cena (epi dê tềs skenềs) a peça tracassou, os espectadores contundiram as coisas ${ }^{(120)}$.

A aliança entre as visőes do artista e do público, sua eminência na obra de arte, tal como acima exposto, nos permitiria anuir: "... é importante para o sentido do texto que o verbo ver mude de sujeito: o olhar do especlador, testemunho da representação em ato, constitui a prova crucial que sanciona - positiva ou negativamente - a coerência do agenciamento dos fatos, frulo do olhar do poeta quanto este colocou para si, tanto quanto possivel, as ccisas sob os olhos ${ }^{\prime \prime(21)}$.

Este centramento no poder discriminatóno do sistema ótico e suas implicaçōes miméticas ampliam-se pela referência ao gesto e a todo o visual do corpo, assim como à perspicácia do autor, proveniente de sua afinidade ou poder de identificaçăo com o personagem. É a finura para desenvolver uma relaçăo simpática - no sentido etimológico, mais literal e mais preciso - ao protagonista, que decide de sua verdade - fundada na semelhança, portanto - e de sua força persuasiva. O poeta mais capaz de sentir-se desesperado, melhor expressa o desespero, o colérico, a colera(122).

Emprestando às nossas palavras um feixe de conotaçőes antigas e modernas, poderíamos dizer que este capftulo constitui um momento de crnica estética, uma reflexăo, no sentido próprio dessa palavra, que movimenta e recolhe - no engendrar, desenvolver e aferir a poesia - a imagem especular entre os interlocutores desse processo, autor e público ${ }^{(123)}$. Assim determina-se a medida poética, em uma escala intemamente definida: mede-se a ficção pela ficção, o olhar pelo olhar, a paixăo pela paixâo, o gesto pelo gesto, a ilusáo pela ilusăo, no horizonte do vislvel que, ele próprio, é inerente ao poema. Trata-se de um amplo e fundo processo de mímêsis dentro de mimésis e o poeta - ponto fixo e unitário - é o métron de sua arte(124).

A opiniăo comum $\theta$ a experiência do corpo formam o ceme intranglvel em torno do qual se consolidam a produçăo artística, as trocas entre o poeta e seu público. A poesia mantém medida própria, Intima, para apreender os componentes invariáveis, organizar a pluralidade, conseguir um todo coeso. Constância, unidade, coerência, firmeza: săo, estes, traços relevantes da concepção aristotélica da arte. Com esta exigéncia integradora, ela nåo se distancia muito das linguagens referentes a outros campos, nem mesmo ao discurso bgico.

Já foi observado que o inf́cio das Categonias distingue o campo propriamente lingülstıco, que se determina por um critério interno - falar com ou sem conexăo - e o domínio do enunciado lógico-ontológico, que se precisa pela atribuiçăo a um sujeito. Neste contraste, o primeiro ponto de vista reflete, de fato, a linguagem corrente, enquanto o segundo representa a linguagem apofântica
1975, p. 199. Curthus indis:a inĝmeras metatoras analoges nas hterat ras latina, groga, judaica o crist3. CI. E.H. Cuiliuv, La ittheratuse ouro. ofenate te te noyen age Lithi. Patis. PUF, 1956. Pp. 168.170.

C). Heifegger sobre o nexo oriqins Ho entre ouyit e vat a 5 ua imbrica-

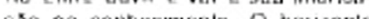
privis mivise centrado nas gregos, cuja existancia stuou-se no plana do "discurso-em. comum" o que tambenn "tinham oibos Dara ver". O autor analisa como o primétro letine desse vinculo sera. rou.se de seu fundamento, com o 10pos concrete testizande para rogos concre uestizando para o enunciado, modo que se atsolutizon na filoscha, cuja logica e calegorias de significaçoes aptisianasam a gramalica. Na tentativa de tecugesar a cuncrefude de dizer e do ouvir, Hosdegger acentua o obo entee jas. cencta arústica b corretoondet - Nato ser acase que diremes nfo Nar e par acaso que difomos nấ mos trem". Mas esta abertuta supho utençâo. um saber-ouvit que pos5vilita escular, combiero que 50 por. do na varolice e na tranalidado.

Feicurso semeltante $\theta$ actompantir. do para o olthar, com sua nolsuel prioridade. At nat por acaso. priondade. Al, nao por acaso, os parametron sas dor por Ajostinno: Ver pertence propria. mente aos olhos mas tamberm empregamos essa patavia para os ou. fros sentidos quando intentarres nit. ra o conhecimento. Nao dizemxas es cuta o que tutila, nom cheire como bribia, nem depuste corro tesplan. aece, nem apolpe com lutee. Mas nac dizomos aponas veja como tuz, que 50 os olhos podem perceber. mas dizemos tarnbêm veja este som, veja este chetro, voja etste sis. bor, veja esta dureza" (Confissóes. $X, 351$. Esta concupiscentia ocusocum, por sua vez, perde.se na curiosidade, na dislıaçáo.

Parolice a curiosidade, modos de gradados do ouvit o do ver reencradados do buvit o do vet reeno outro". ICt. M. Heideggar, L'blre et le terms. Paris, Gallimard. 1964. pp. 199-213 (\$ 34.37).

114 Podica, XXV1, 1462a $2 \cdot 4$.

115 Pósinca, XXVI, 1462 a 10-12.

$116 \mathrm{Cl}$, P. Chantrainne, Dictionnasse stymologique de ta langue grecque. verbete phalmo, p. 117 t. lexs. phaverbele phalmo, p. 117t. lexs. The-
sis, aparencia e enunciaçato; apogis, aparencia e enunciaçá, apo-
phafnein, lazer aparecer e doclarar. orophasis, lenomeno precursor. primeira manilestaçáo de uma doenca, e protexto, o que se alega).

117 Postica, XXVI, 1462 a 15-18.

118 Para as dilerenças radicats entre as feotias oticas modernas a anligas, com a necessidade de "um estorço de reconstifuiçáo quase elnologico" de conceitos centrals para os gre. gos, of. G. Simen, le regand iste gos. ct. G. Simoni le regard. Metre 1979. Ct. espetialmente as consioe raçoes sobre o modo como se telacionam luz o olnat, sobre a "quase materialidade- da imagem (efdolon), sobre a orientaçăo Nundamental para o vislvel, cingido ao aparecer. Para a discussto roterente a Aristoieies, ct. pp. $42 \cdot 43$.

119 Poefica, XVII, 1455a 22-26. De outro êngulo. Proust nos diz:
-... le style pour l'écrivain, aussi bien que pout le peinten, est une question non de lechnique, mais de vision... Par lart seulement, nous pouvons sotlit de nous, savoir ce que voil un autre de cet univers qu n'est pas 10 meme que lo notre el dont les paysages nous seraient 
cestés aussi inconnus que ceux quil peut avoi dans la lune", kitado po A. Beguin, r'sme romuntigue at ie Ave Patis Josه Corti. 1939 of 3731

120 posted. XVil, $1455 \times 26 \cdot 29$

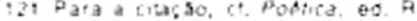
Dupont Roc o I Lation, nota 3 a

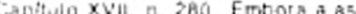

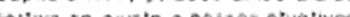

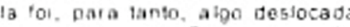
de seu contorlo. Os auvies nac vecusam o estatuto do oltar. nat cogitam das ilusoes otucas projetadas oute poeta o espectador. ná atentam para a trama especula chatora o cecoptiva oue os enlaca. a minuciesa e muto percusien. andire anguse irvela tormulasto. mas, inlelis mente, foram sosyistacos nas im poltantes compalaçoes teitas cont a

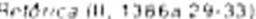

Os autores indicam a groxmedade

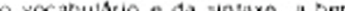
edentes droremas de sortido. A feu ver, no caso da relorica, odo diance dos ofmon" \& crial a ilusto of to. Dolo eccurso al íguras do lin guagem, latendo disim valece

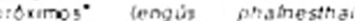
contecimintos distantes no rempo. to, a aça o representada em aro. tsis contrarite tra: mpltcita a useis e que. A aç, om a ofo, seja e5t/a tho o asatate llusdrio investido n nteroretaça. Na vortade, ete fuplamente investido na tramatur. "esplande a inirios o poeta

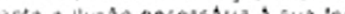
A

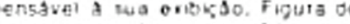
inguagert ou liguta diamática, arr bas se delineiam no sensfvel. n. pparencia o phalmesthal essen zi a ambas.

Simeinate equfroco tepete-se

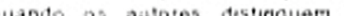

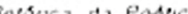
tue a crimeria visa interpretar. e equata produz: seros. Em apolio 10 atastamento ontre os do:s atro embram a vierensa ente "coloca

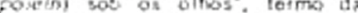

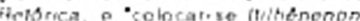
50t 05 olhos. lerme ta Postica.

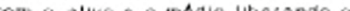
dos processos. Heportam, ademats - Bormuta ga Pobrica s invença. Do passagem, valolia nota? que o verto jorein no tontoxto da réborica, náo eats imune is twas conotactes in rentras Entrotan: o moertank

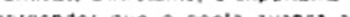
"herer. ba

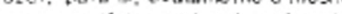
etutso meto deco utilifado pelo toto fiate on sau triblico. A totca que retor impuisiona diretamente na al as atrela, o poeta o taz num torneio yonico, byencose mbicara d miscara.

122 Pothes, XVII, 1453 a 29.34.

23 fiss urcotemsica leverseta na cultura modoena. 14. porom, dito enjas o beo voshiza para o ator.

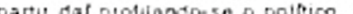

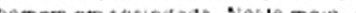

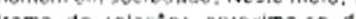
rama Je relaçes apronima-se da acime descitia. No Paradove sur ie combien do Oiderot ato: e públice lornarn-se tora de st, mas de manei a diversa onguantes o prime iro desempenta, nac of o peronager. segurdo deirarae absorver nelo. - Se pomen unotiol no teatro. Secompoe em sua alionargo. secompoe em sua allona,so. 0 an ou artusta neia do constitul Nao se entegandso ao objeto imagintrie. beu serzonagem, eto tao mesmo tempo oltha oste porsonazem, sar "visando esciarecer a linguagem nalural no sentido de que melhor se ajuste às coisas que sāo, que vèm a ser, ou que serăo. O Estagırita edifica esta linguagem com o lito de exprimir, o mais naturalmente possivel, certa reaiidade, aquela que pode ser relerida ao que e, ao ente. Trata-se, para ele, de estabelecet o verdadeiro e o falso e, por conseqüência, circunscrever as condiçōes de uma ciència das corsas sensfveis e em devir" (125).

A elaboração deste discurso pode ser acompanhada nas minuciosas advertências sobre o raciocínio correto, nos Tópicos. Como sena de esperar, o capflulo sobre as definiçōes acentua os requisitos para manter unívocos os termos, elimınando todo e qualquer traço ambíguo ou obscuro: al, a elocuçāo (herméneia) precisa ser clarissima (saphestat), pois seus proposito é "fazer conhecıdo" (gnōrisai). Num sơ fôlego, afirma-se a nitıdez da expressåo e a evidência do conhecimen$10^{(126)}$.

Essa prosa, deliberadamente náo-literána, votada ao exato registro inteleclual, extirpa de seu corpus uma das figuras mais atiladas e finas, mais conformes ao gosto grego: o jogo de palavras. Este mobihza, por vezes, năo apenas as mütıplas camađas e valores das significaçōes. mas, conjuntamente, a própna inserçáo dos significantes no texto. produzındo um eleito plástico de profundidade e relevo, inesperada e intensamente evocador de vários e acumulados registros semàntıcos e doutrinánios ${ }^{(127)}$. A definiçáo, unívoca e conversivel em seus termos, s $\delta$ pode ser unidimensional, assim como o discurso em que se inscreve: este, em vez de resultar num agen. ciamento conciso. em que pese sua exigència de eliminar o supérfluo, compōe um meio nem sempre económico, mas seco, plano, igualizado, monótono, de acesso menos diffil, talvez, que árduo e cansativo ${ }^{(123)}$.

Aristóteles, como seu mestre, afasta a poesia do sábio. Mas de maneira diversa. "Plato, whosoever considereth, shall find that in the body of his wotk, thought the inside and strenth were

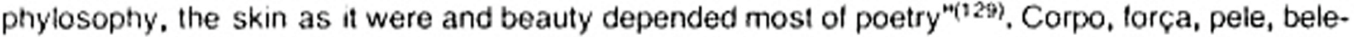
za: a imagem de Sidney renova o commonplace renascentista - Platāo poeta - enfatizando todo o poder sensivel volatizado pela crftica moderna. Năo excluindo a poesia de sua própria escrita, mas incorporando-a no debate filosofico. Platão ergue-se do mundo arcaico, onde a tragédia e dialética enlaçarn o verdadeiramente contradióno em confrontos enigmáticos e combates arriscados, e ao mesmo tempo se alia à corrente mais contemporánea, onde as oposiç̋́es se abrandam na maior publicidade $€$ no menor empenho das dispulas retóricas. Em contraste com o elogio da palavra viva, potente no ataque e na delesa, que vemos no Fedro. "Platāo é dominado pelo demôno da literatura (...) seu mais forte instinto fot o do letrado, do dramaturgo" ${ }^{\prime 130)}$.

Em Aristóteles, a separaçăo explícıta entre linguagem poética e filos b́fica e mais cortante: voltadas para campos diferentes, pertencem a gêneros distintos. De lato, a ruptura é menos completa. Consideremos aiguns exemplos onde se instala a desconfiança conceptual da linguagem figurativa, retornando às definiçóes e à exigència de clareza, aos pengos do enunciado incorreto.

"Tudo o que é por metátora é obscuro", sentencia Anstóteles no Tópicos ${ }^{(131)}$. Na Poética, a atitude tace à metálora es muito discreta, tendendo para a descrição de seus procedimentos ${ }^{1321}$. $\mathrm{Na}$ Retórica, além dos cuidados imprescindiveis à montagem metatórica, aparece um empenho maıs crítico, nuançado pelo debate sobre a justeza ou nåo de seu uso. Entretanto, certa avaliação positıva é inequivoca: mesmo na prosa. é a metáfora que proporciona a clareza, o prazer, o estranhamento (tó xenikon $)^{\{133\rangle}$, traço este valonzado por ligar-se à elevaçāo do estilo. Aristóteles chega mesmo a afirmar que a metátora deve ser produzida a partir daquilo que é própro (oikeios). mas nåo do evidente (phanerós), assim como em filosofia é preciso sagacidade para apreender similitudes que såo distantes. Várias vezes Aristóteles afirma que as expressỏes finas e cultiva. das, elegantes, "urbanas" (tà asteía) derivam de metáforas ${ }^{(134)}$.

Apesar da censura na frase acima transcrita, a despeito da insistência em desunir prosa e poesia, algo da acolhida favorável à metálora subsiste nos Tópicos. A transposiçăo de sentidos, justamente por mobilizar conteúdos e informaçōes tamiliares, usuais - tal como terra nutriz - torna reconhecivel (gnörimon) o significado que se pretende evocar ${ }^{(135)}$. Por essa via, os procedimentos metaforicos guardam resquicios de valor cognitivo e recebem, na hierarquia dos enunciados, uma avaliaçăo positiva. Embora postos em grau inferior às regras do método, recursos válidos para a verdade e a eficácia pó́licas - a imagem e a imitaçāo - transferem-se para a escala atendora da verdade e da eficácia ßogicas. Sua aceitaçăo é toda condicional, por certo, mas contrasta nitidamente com a recusa terminante das representaçőes que Anstóteles considera nulas, destituidas de qualquer lastro concreto.

"A lei é medida ou imagem do que é justo por natureza." Esta assertiva é pior que a metáfora ${ }^{(136)}$. Nảo produz o reconhecivel, náo encontra amparo seja em símiles, seja em sentido próprio. Nem existe semelhança segundo a qual a lei seja medida ou ımagem, nem ela é assim chamada de modo imperante ou coslumeiro. Portanto. "se alguém diz que a les é medida ou imagem é falso (mentitur, traduz o latim), pois a imagem é prođuzida por imitação (diả mimesēós). o que náo ocor- 
re na lei; se náo diz literalmente, ê vislvel que lala de modo obscuro e pior que qualquer dos pronunciamentos metaforicos"(137).

"Tudo o que năo ê costumeiro é obscuro."(13e) Esta, a fonte da nitidez mínima conferida à metáfora e negada ao vocabulário destituldo de referência direta na base efetiva, sedimentada no meio social. Neste passo, o alvo acertado com força é Platâo, por fugir dos hábitos coletivos e usar temos bizarros, como "olho-de-cenho-sombrio" (ophrybskios).

Na Poética, Aristóteles propōe, explicitamente, a questăo do nome "fabricado" (pepoiëménon): trata-se daquele usado exclusivamente pelo próprio poeta que o inventou, nada significando fora desse destino(139). O artista dispôe (tithénai) a palavra. Também a Retórica identifica este artiffcio, admitindo as construçōes menos forçadas, principalmente as resultantes de palavras cujas formas se combinam com facilidade ${ }^{(140)}$. As duas obras colocam b́bices contra os vocábulos inventados pelos poetas. A primeira vista, elas parecem apenas constatar fatos, sistematizando os estratagemas; pouco a pouco suas resistências, inclusive para a poesia, văo se delineando. Este caso extremo - o nome fabricado - pertence à problemática mais ampla da clareza vinculada ao costumeiro, ao uso comum.

Também para o poema vale a afirmativa de que a expressão mais clara ê a usual. Esta, contudo, desce ao comezinho, "baixo". Para conseguir elevaçăo de linguagem, é preciso usar termos inabituais, "estranhos" (xenikof), afastados do dialeto vulgar (141). O próprio assunto e personagens poéticos distanciam-se do ordinárió(142). Há, portanto, af, nåo apenas um registro das Iécnicas artísticas, mas certo julzo positivo da linguagem que foge ao corriqueiro. Is to se fundamenta, paradoxalmente, pelo retorno à opiniāo geral, repondo-se a validade de suas sentenças.

A Retorica nos oferece o enquadramento dessas normas. Também nela, a exigência de clareza é reforçada junto com o requisito de elevação imprescindlvel à poesia: as palavras correntes garantem a primeira, as "estranhas" permitem a segunda. O extraordinário, o alheiado, fazern aparecer (phainesthai) a maior dignidade. A este respeito, os homens sentem face ao estilo o mesmo que frente aos estrangeiros ou concidadâos (pròs toùs xénous ... pròs toùs politas). Portanto, deveriamos fazer "estranha ( $x e ́ n e ̂)$ nossa língua, pois o remoto é admirado e o admirável é prazeroso"(143). Entretanto, mesmo em poesia, todo cuidado é pouco: o abuso de nomes fora do comum arrisca tornar-se enigmático ou blablablá (barbarismós), a fala incompreensivel do estrangeiro ${ }^{(144)}$. Na prosa, a ascese é mais estrita: ela é o lugar, por excelência, do imperante (kýrios) e do próprio. familiar (oikeios) ${ }^{(145)}$.

Esses reparos mostram o quanto é tenso o programa de estabelecer uma linguagem peculiar e adequada à exposição logica e cientffica, o quanto Aristóteles permaneceu preso, de modo paradoxal, por conta da exigência mesma de fazê-la clara e distinta, às outras linguagens da qual procurou diferenciá-la.

As passagens acima evidenciam também que nem mesmo Aristóteles escapou ao fascínio do jogo de palavras, recurso por ele tematizado, com suas ambigüidades e ressonâncias, como boa arma para o retor. O verbo exallássō, várias vezes usado naqueles contextos, comporta uma cadeia de sentidos em torno de mudança e distanciamento, indicando particularmente a troca de pals. Esta expressăo assume um sentido ampliado por todo o campo semântico desse entrecho, acentuando a estranheza das palavras fora do comum, do dialeto alheio, superpondo-se de modo polissêmico a xénos, xenikós, bárbaros, significantes cuja força também se multiplica. De outra parte, todo esse conjunto se opঠe à lingua do polnēs, o idioma interno, justamente familiar, doméstico, oikeios. Todo esse travejamento do texto sustenta, na doutrina aristotelica do estilo, uma poderosa carga ética e social, assentando o discurso sobre o politicamente estabelecido, cristalizado em suas clivagens.

Na cultura moderna temos um exemplo pungente desta estranheza entre a lala do poeta e a escuta do vulgo. Hölderlin, o "homem da Grécia, ferido pelo deus Apolo" (D. Janicaud) deve muito de sua pretensa loucura a psiquiatras, médicos, filosolos, sediços conhecedores da língua grega $e$ do trabalho poético. P. Bertaux, uma das maiores autoridades sobre o artista, nos diz que para ele "a poesia é um meio de açăo, o poema, um ato". Mais precisamente: "Para Hölderlin, assim como - pensa ele - para os gregos, para um Pindaro, a arte é artesanato, técnica. A estética, nåo existe. É belo, o que é bem feito (...)" Hōlderlin quer atingir a mēchanē dos poetas antigos: "homens de oficio, o que thes dava ao gesto uma excepcional segurança. Nem hesitaçăo, nem fraqueza: eles sabem o que såo"(146).

Astúcia - mechane - artesanal e polnica. Exortando o povo alemăo à liberdade e democracia - na hora em que os principes contrários à Revoluçăo Francesa sujeitavam corpos e esplritos - Hölderlin utilizou a estratégia de falar as coisas sem o ar de dizê-las. Apesar disto, a frase, em suas obras, continua "de exemplar firmeza de linha, os termos de uma precisão absoluta". Este decorum faz dele um emulo da literatura grega: "a extrema precisăo destes escritores, diz, é con- imita-10, trabaina-10, assim como o espectador, para dosat seus eloitos". A attvidade do ato supoe. om contrapartida, a do público, torman. do "um conjunto do olhares, uma estrutura revarsivel. Onde aquole que vo pode tornar.se visto, o os. pectador tornat-se espetsculo (...) E o olho, o o sistema do olhar produ. zido, que travam a causalidade it. neat om um sistema de ricochetos". cr. M, Hobson, "Sengibitite of spet cle: le contente medical tu paradoro cle to conterto medical du paradox sur lo cornbolien in havue de Mótaphysique of de Morale, Paris, 1977. pp. 162-163.

No mbtodo acima descrito, o ator $\Delta \circ$ instrumento que alere a sensibilida. de do poblico. pormanecendo ele proptio insenstvet. Para constitui, assa escala de modida, o stor se neutraliza: actoditasso ole em suas proprias lagrimas o so tornaria incapaz de um desempento continua. do e coerente. Nota-se, aqui, a difo. rença trente a "simpatia" preconizada por Aristoteles, resultante de concepçoes distintas sobre relaça arte natureca $\mathrm{Em}$ Diderot, a prima ane-natuca. Em Diderot, a primel "Em todos os casos. O mundo no qual as pessoas reagem de modo diroto 2 espontaneo o um mundo onde a expressalo e freguentemente per. vertida. Quanso mais a expressac dos retes humanos o naturat, tanto menos eta 1 em possibitidade do monos". Esta hossibilidado de ser crivel". Esta hegemonia do artiffcio que. perteito ator, o explora na conduçao das massas. Ct. $\mathrm{A}$. Sonnet. Les yrannies de rintimvis, Patis, Souli, 1977, pp. 96-97.

124 Para uma discussso mais ampla, sobre a medida em Aristoleles, cl. L. Coloubatitsis, rotte et run choz Aristole" in Revue de Philosophie Ancionne. n. 2.1983، D. 168 . segs.

Outras sugestoes no sentido que proponho, podem ser colthidas no proprio Aristoteles, ct. por exemplo. E. Barbotin, Elevation spatiale of tanscendence onlologique seton Aristoto. Propos dihiswire ot de cri. tique." in Endrgeis. op. cit.. pp. tique. 185.101 .0 autor, 'effetindo sobre
os venculos entro o corpo. O univer. so 0 o pensamento metallsico, os creve: "E que o corpo humano Aristoteles o sublinha - A orientado: sua estrutura anatomica apresenta um alto e um baixo. uma dirgita e uma esquerda, um adiante $\mathrm{e}$ um atrás. (...) Nos eurpreendemos do ver o Estagirita atribuif so universo um alto e um baixo absolutos - de fato, rolativos a nossa estrutura cor. poral. O importante of que as con. ceitcs assim emparethados se ental. zam om nosea experioncia do pro. prio prio corpo. Esto desomponha um papel do instrumento de incerpir ça., de "chave hemenoutica' " forilo mou). O autor continua com refle$x$ oes paratelas sobre a linguagom. Esse procedimento pode encontrar paralelo na medicina, tantas vozes considerada por Aristoteles. Num dos tratados hipoer sticos, o autor reciama a nocessidade de alguma meciama a nocessidade de alguma pudesse alcançat um conhecimanto oxato, concluindo que ola so pode. ria sei encontrada na "sensacso do corpo" (tod somatos ton alsthezin). C. Modicina antiga, IX. A esso ros peito, escreve P. Lain Entralgo: "Com a sensibilidade de seu proprio corpo. o medico percebe o que para ele sensfvet no doente. 0 corpo desto, - nisto lern o mais soguro critorio de certeza: tal loi, entao, a regra do ouro da modicina ociden. 
tar. Cs. La relación madico-enter mo. Madrid. Alianza, 1923, p.64.

$125 \mathrm{CL} L$ Coloubaritsis, regcenenon et Kat goroumenon chez Aristote" in Philosophie du tangage el grammar. re dans rantiquilde. Bruxelas, Ousia, 1986. pp. 219.220.

126 ropicos. Vi, 139a 1.4.

127 Toda uma cadeia de cultura se esta. belecou em sorno deste tecurso de pensamento - linguagem, bem conhecido na cultura grega e muito ampliado, juntamente com sua crhilca. a partit do Renascimento. Nas palavias de um tolor seiscentista, o palavt as de um tolor seiscentista, o
jogo de palavras of figura do wit. "an affluent spirit, yiolding invontion to praise or dispraise. Of anie ways to duiscourse with judgement to every ubbject". Vivacidade, tapidez, argó. cia acumem igeniorum, na explot. so de Clcaro. Nesta lineza do enpt

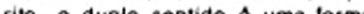
forme que "desata as coisas, destaz on nos", rompendo com o esteriotipado, quebrando os raciocinios lineares e as significacoses congeladas no idontico. Assim como a liberdade do espofito (Geish nato a negar de um encedenmento, mas, de un estado positivo, 0 ongonho (WViz) nao apenas uma outra lorma que repetiria uma outra foma mudando sou gigno: ole o tambern, o so mesmo tempo. - sompre, una torms criadora de mane it aulonoma $t . ..)^{\circ}$ Ct. A. Jolles, Formos simples. Paris, Seuit, pp, 198 o 206. Para a imr portancie da polissemia no perfodo arcaico, na Grocia. ct. Coloubaritsis, Mythe et prillosophie chez Par menide. Brurelas, Ousia, 1986.

128 Nesse sentido. nada mais agudo que a ironis de um fine witted poets seiscentista que, colhendo uma lon. ga tradiçào, opon a torca da poesia como spoaking picture as sutilezas dos herdeiros de Aristoleles: dos heideice do Aisiole les: 0 on siname to do mint wollo is ta no man read him with attentive studious painfulness: wich constant desite. whosoever hath in him, hath altoady passed hall the hardness of the war. and theretore is boholding to the philosopher but lot the other halr. Cl. Sir Philip Sidnoy, An apology tor Cl. Sir Philip Sidnoy, An apology tor poedr. ed. F.C. Robinson, Indianapolis, Bobos Niso ef dilfil que Sidney esteja voltando contra Atistoleles as suas proprias painvias. Lembremos todo o contexto do livto, onde se trata da anterioridade do ato sobre a poiton. cia, 16goi, oustai, chronoi, Negte at timo caso, olv Dode ou nas set tal.  do 0 qua 6 gorado. gerado de ar 9o. por algo. Sorma imente identico a oie groprio. Parece imposstrel que - construtor o seja sem nada ter construldo, o citarista sem nunca ter tocado chara, pois quem aprende Dosdo que algo rado is tol gerado a a go que esta sendo movido como um todo is loi movido (...) igua mente aquele que estuda possui, por necessidade. al. guma coisa da ciencia. Metallst. ca, $\theta, 1049$ b $19-1050$ a 35.

Encontramos om Hobbes palavras proximas is de Sidney. "(...) Scinn. ce is of that nature. as none can understand it to be such as in a good measure have attayned if. Lovis. than, I, 10. (od. de 1651, p. 42)

$129 \mathrm{Ph}$, Sidnoy, An apology lor poptry. op. cil., p. 8.

$130 \mathrm{Cl}$. G. Colli, La naissance de la philosophie. Edilions de L'Aire, 1981, p. 120. seqüência de seu poder intelectual" (Carta a Schiller, junho de 1808). Como Hegel, prefere Solocles; em filosofia, escolheu Empédocles, Icones da trágica e aristocrática liberdade grega.

Para os famosos companheiros de seminário - os jovens Hegel, Hölderlin e Schelling - os ideais polficos antigos vinculavam-se inextricavelmente aos outros setores da cultura, com predomínio absoluto da poesia, em seu despojamento e concretude. A abordagem holderliana aliou, ao anseio republicano. "uma tentativa de transposiçăo do fraseado grego para a lingua alemă. Existe, pensa Hölderlin, uma prosódia do pensamento poético, em imagens; é ela que se trata de restituir, com o preço de alguma violencia ao discurso". A violaçăo das regras costumeiras trouxe ao poeta um duplo dilaceramento: polticico (prisăo, clínica psiquiátrica, "tratamento" de conseqüências indeléveis) e cultural (a começar pelo riso irônico de Schiller face à estranheza de seu Sólocles).

"Um cavalo de batalha para os psiquiatras, é a propensåo, diz-se, de Hölderlin, para fabricar nomes novos que năo têm sentido a năo ser, talvez, para ele." Kamalatta, Killalusimeno, Pallaks. ch, săo alguns desses termos. Alguém ouviu o poeta exclamar, sobre Ésquilo: "mas esta ê a lin. gua de Kallamata". Trocados o / pelo $m$, a cidade do Peloponeso onde se situou um episódio central de seu romance Hyperion, torna-se irreconheclvel... Um visitante escuta-o dizer: "mudei meu nome. Eu me chamo Kallilysómenos." Ou seja: "eu sou aquele que encontra uma bela solução para seu problema". Lysómenos (participio futuro médio de lýö, deslindo, paradigma das gramáticas gregas desde o Renascimento), unido ao prefixo kalli - lorma o neologismo fabricado por Hölderlin. Mas em lugar de kalli - o vulgo escutou killa... Pallaksch, palavra que o poeta dirigiu a um belo adolescente, mau conhecedor do grego. Acrescente-se a pronúncia suábia, e a palavra pallax, jovem, perde o sentido para transformar-se em balbucio demente ${ }^{(147)}$.

"Pois o afastamento em relação a forma corrente das palavras, chocando-se contra o hábito, produzirâ o invulgar." Hölderlin praticou isto, antecipando o estranhamento que mais tarde Brecht batizará de Verfremodung. Para sua desdita, fugiu às regras enunciadas no momento seguinte da frase aristolélica: Freqüentar o habitual, assegurará a clareza ${ }^{(148)}$. Incomum, o poeta revolucionário e cosmopolita tornou-se hermético para o alemão, povo sobre o qual já dizia: "encontrarás nele operários, pensadores, padres, senhores e escravos, jovens e adultos. Mas nunca um Homem" (Hyperion). Entre as virtudes domésticas e as exigências da poesia, o choque é perene.

"Nos Iragmentos de uma tragédia, A morte de Empédocles, Holderlin desenvolveu a idéia da missão do poeta opondo-se à mesquinhana quotidiana." (M. Alexandre) Por certo. Entretanto, o mais violento, no enigma apresentado por este escritor, ê sua piena consciência da impossibilidade, brutal, de comunicaçăo entre o produtor e o consumidor da palavra: "mais vulgar, mais diário tem de se fazer o fruto, entăo ele pertence aos mortais ${ }^{w / 149)}$. Das traduçōes hölderlianas, disse W. Benjamin: "os portais de uma língua ampliada e tâo intensamente elaborada ameaçam abater-se e murar o tradutor no silencio ${ }^{m(150)}$.

Visto o inabitual - a lala poética e seu estranhamento repercutindo na parede entre escritor e público - podemos considerar o outro lado da tese aristotélica, a "claridade" trazida pelo costu. meiro. Num estudo bastante amplo sobre as relaçőes entre poesia e hábitos burgueses - a doçura do lar - R. Jauss indica o sistema silencioso de constrangimento, delinidor das normas comportamentais. Estas, uma vez estereotipadas, tomam-se praticamente invisiveis. Todos a elas se rendem, "sem tomar consciência de suas regras". Mas uma saida pode surgir com a literatura e a arte. "Esta é uma das contribuiçōes mais importantes, embora pouco estudada, que a experiência estética pode trazer à práxis social." Conseguir que as instituiçōes mudas falem, tematizar as nomas, justificá-las e transmiti-las, lazendo emergir o caráter problemático do constrangimento trazido pelo mundo institucional.

Para localizar as normas "invislveis" que regem uma sociedade, sâo necessários, diz Jauss, "O estrangeiro e o historiador... com seu recuo e distância". Mas também o poeta, ajunta o crfico, citando Baudelaire:

\section{Encore la plupart n'ont-ils jamais connu}

La douceur du foyer et n'ont jamais vécul

Seu comentário é elucidativo: Baudelaire seguramente deu a visăo mais poderosa daquilo que "o repouso da tarde, terminado o dia, traz à lamilia burguesa, quando o céu envolve a cidade como uma grande alcova (...) Evocado na perspectiva dos excluldos - prostitutas, criminosos, jogadores, pensionistas de hospitais - o tema já banal da felicidade ao pé do fogo recobra, em Le cré. puscule du soir, como o patético da negaçăo, uma força poética dolorosamente penetrante".

Enquanto Baudelaire desnuda a falsa tranqüilidade doméstica, Victor Hugo, em La vie aux champs, movimenta lugares comuns numa didascália piedosa: "vemos o poeta na situaçăo de 
narrador junto ao fogo, dizendo às crianças como é preciso pensar, sonhar, procurar, e dandothes conselhos mais ou menos solidos, concretos: a quem dar esmola e como receber ensinamentos ou correçōes dos pais. Todas essas liçðes morais coroadas baseiam-se na promessa de que ser born é viver bem, vindo acompanhadas por uma pequena teodiceia: Deus nada tem a ver com o mal, logo, o homem pode encontrar a 'bondade' até na dor e nas lágrimas"(151).

Estranhamento em Baudelaire, pacificaçăo domesticadora em Victor Hugo. Af temos, na Modemidade, o desdobramento da norma aristotélica e suas implicaçōes, a contraposiçáo entre tó xenikón e to eiöthōs.

R. Sennet mostra as conseqũências últimas nessa "doçura do lar" ao descrever os efeitos danosos de sua tirania, sob lorma doméstica $\theta$, um pouco mais ampliada, "comunitária". Nesta última esfera, sublinha: "é dilficil empreender açōes coletivas, porque as pessoas se preocupam, antes de tudo, em saber quem pertence a esta identidade... e quem deve ser excluldo. Uma tal comunidade ŝ hostil aos outsiders, e há competiçăo entre seus membros para saber quem encarna, 'realmente', a personalidade coletiva, quem é um 'bom arnericano', um 'puro ariano', um 'verdadeiro' 'revolucionánio' ".

Resultante dessa fobia pelo estrangeiro, ocorre, na comunidade. "uma fuga do contacto, uma procura de solidảo e silêncio; para năo demonstrar sentimentos, se prelere não mais experimentá-los". Pacificação nos limites da passividade, morte da res publica. A vida civil esmaece, a "comunhăo intimista faz do 'individuo' um artista privado de arte". Qualquer poética torna-se imposslvel, a polftica prende-se exclusivamente à retorica: "toda liderança moderna é uma forma de seduçăo"kis2).

Consideremos as reflexōes de G. Colli sobre a retorica e a dialética. A comunidade moderna aparece como um lugar da harmonia; entretanto, subjacente a ela, uma regra geral: a exclusão do estranho. Para isto, é preciso persuadir os "iguais", ceme do próprio invento retórico. Enquanto na discussāo dialética o combate é para vencer o ađversário, apanhá-lo nas armadilhas do raciocínio, no discurso retórico o orador luta para subjugar a massa de ouvintes ${ }^{(153)}$.

Em sua astúcia, a repetiçăo do habitual - o conhecido - ê uma das bases para a instauraçăo tirânica e pacificadora da comunidade. Corno bem diz Shoshana Felman: "toda prática lingülstica repetitiva veicula uma poténcia hipnótica que induz o individuo a comportamentos sociais ou mentais estereotipados ${ }^{\prime \prime(154)}$. De Aristóteles a nossos dias, registra-se a luta entre liberdade de invenção e discurso impositivo.

O suporte no costumeiro, o todo unificado, coerente, tempo e movimento minimizados: face a este quadro estável, vejamos o elernento perturbador por excelência, o acidente.

\section{O acidente: elemento perturbador subjugado}

A traduçăo de symbebēkós por acidente marca a idéia de "cair sobre" (accidere), advir num encontro ou reuniăo, esmaecendo o componente metafórico de andar junto, de caminhar no mesmo passo, com o amplo espectro de coerência e mesmo harmonia presentes no verbo grego. A leitura parcial de to symbebēkós acentua seu caráter fortuito, imprevisivel, sem constancia ou finalidade ${ }^{(155)}$. Nessa vertente, săo ineludiveis os embaraços com o texto logo abaixo ${ }^{(156)}$, relativo ao symbebēkós kath' hautó, isto é, aquilo "que existe em cada coisa, conforme ela mesma, mas năo em sua substância (ousia)". Tricot, em seu comentário, pergunta-se como ligar a acepçăo precedente a esta última, "que parece não apenas distinta, mas quase contrária"(157). Alguns autores indicam uma possivel conciliaçăo a partir de Bonitz, em seu comentário ao silogismo ${ }^{\text {(150) }}$, onde, isolando a noção de fortuito, acentua o significado de symbainein como acontecimento (evenlum, que envolve também a idéia de conseqüéncia), reportando-se a ele, por isto, as conclusరees que resultam (eveniunt) das proposiçōes.

Encontramos uma atualizaçăo dos problemas referidos ao acidente, em A. Urbans ${ }^{(159)}$. Suas análises tocam pontos delicados da doutrina aristotélica, revendo as teses da náo-cientificidade do acidente, de sua vizinhança ao năo ser e existência apenas nominal. Discute o suposto das causas fortuitas, indeterminadas e exclusivamente materiais, aventando a possibilidade de uma causa formal para o acidente atribuldo. Suas discussőes săo pontuadas - de modo terminante para os resultados obtidos - pela passagem do plano estritamente lógico para o da efetividade, para o mundo sensivel, "real". Entretanto. pelo teor mesmo do trabalho, suas análises sobre a "estrutura da linguagem" fecham-se nas articulaçठ̄es logicas.

Deste modo, a gramática, a sintaxe $\mathrm{e}$ a semântica săo entendidas estritamente naqueles limites abstratos, nunca se reportando ao exercicio eletivo da lingua - á sua poética e retórica nos textos de Aristóteles. Alheiamento este, que acarreta trånsitos surpreendentemente sumários entre o "ser e o discurso do ser". Veja-se, por exemplo, seu arrazoado relativo à impossibilidade
131 Topicos, V. II, 139b 25-26, Um av tor moderno, admitradot de Arisos. lelos, pareco acoiner e ampliar tavis posiçes: "Na prosa, os antigos mantive: art se longe do uso excessivo de motatora devido a intinita claridade (unendliche Klatholl) maiesbilidade de sua lala e. na poesis, dovido a seu came per. leito sentido plastico".

Em sentido plastcon. Em outra obra. O masmo autor focaLa diretamonte Anistoletes. a ex celencia de seu idioma fitorolico -Falta certamento em Aristoieles, a bela forma de Platso. esta doçura da linguagem, asse tom de conver. sa: vivo, cultivado, humano, Mas no Timen onde a icóia especulativa timev. ondo a icoi especulativa expressa om torma de lese. pode mos porceber o guanto ha nelo de impuro e delelivoso. Isto conttast com Aristoteles, que sabe recoliho-1a - entender em toda sua puroza", Cl. C.W.F. Hegei, Estólica e historia de hlosolia, in Worke in zwanzig Ban den, I. 13. D. 522 e II, 19. DP. 147-148, respectivamente.

132 Postica, $X \times 1,145707-33$.

133 Resonca, II, ix, 1405a 7.8.

134 Aelorica. III, ix, 1412 a 5.

Uma bela reliexaso sobre ostito o verdade - metatora da escrita - nos $\checkmark$ oferecida por Proust: "Une heute n'est pas une heure. c'est un vase cemplit de partuns, de sons, ife cit. mats. rappont unique que roctivain mats.. rappont unique que rocrivain . - jamar dans da phrase leo deux lermes dillorents. On peut taire se succeder indotiniment dans une description les objets qui figuraient dans lo lieu decrit, la verite ne cormencera qu'au moment où recii. vain prendra deux cojets ditforents.

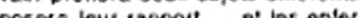
posera leur rappori... ef les entermera dans los anneaux nocessaitos d'un beau style. ou mome, ainsi que la vie. quand. on rapprochanl une qualite commune a deux sensations. il degagera lout ossence on ios i Au nissant tune of rautre pout les soustraite aux contingences du temps, dans une motaphore, ef les on chainera pat te lien indesctiptito tuanera par lo lien indesctiptible drune aliance do mots: M. Proust. citado por A. Beguin, in Lamo 10 mantique of lo rove. Paris, Jose Corti, 1939, p. 355.

135 Topicos. VII, U, 1396 39.41.

136 ropicos, Vi, II, 139b 38-39.

137 Topicos. VI, H, 139b 42.47 .

138 Tdpicos, VI, $4,139 \mathrm{~b} 35$.

139 Podtica, XX1, 1457b 34.35.

140 Retorics, Iti.

141 Podbica, XX11, 1458a 19-23.

142 Retorics, III, 1, 1404b 3.

143 Retorica, III, I, 1404b 2-3.

144 Poostica, XXII, 1458a 25.

145 Retorica, ili, ii, 0.

146 Hotdertin ou te temos fun podto, $P$ Bentaux. Patis, Gallimard, 1983.

$147 \mathrm{Cl}$. D. Janicaud. Hogol of le destin de la Grece. Paris, Vtin, 1975. Tambern: P. Bertaux, Hodterin ou to tomps d'un podte, Paris, Gallimard. tomps
1983.

148 Pottica. $X X 11,1458003-5$

149 "Mas a lingua..." Trad. Mário Ouin. tans.

150 Citado por Haroldo de Campos, in A operacáo do toxto. Sa Paulo. Perspectiva, 1976, p. 90.

151 Pour une esthdigue de la reception. H.R. Jauss. Paris, Galimatd, 1978. 
de uma predicaçăo acidental prosseguir ao infinito: "Aristóteles mostra muito bem, neste ponto, que a fim de cumprir sua funçāo de predicado, todo acidente deve determinar-se semanticamente. o que vem a dizer que ele nåo se analisa numa série infinita de significações (...) resulta que a linguagem ê um reflexo fiel da realidade, pois do mesmo modo que uma infinitude atual de predicados nåo pode ser atribulda a um sujeito, assim também uma infinitude atual de atributos não pode ser atribuida a uma substância". (p. 166)

Interessa-nos, aqui, assinalar alguns resultados de suas análises. Examinando os Segundos analibcos, o autor focaliza a assertiva que divide os acidentes em dois campos: "Sâo, com efeito, todos symbebēkóta, mas alguns per se (kath' hautá), e outros de tipo diferente". Para ele, 0 inicio dessa frase (symbebëkóta gár esti pánta) năo é surpreendente, à semelhança dos Topicos: "Tornado como termo geral, symbebēkós significa somente predicado ou atributo". A partir desta abstração. Anstóteles introduz, em seguida, a diferença (kath' hautó e kath' héteron trópon). (p. 95)

Todos os predicados aplicam-se ao sujeito, distinguindo-se pelo modo proprio de pertencer a ele. Deixar na sombra esse caráter fundamental, acarreta, ao ver de Urbans, tropeços diante do symbebēkós kath" hautó: ao traduzir essa expressão por "acidente per se" corre-se o risco de imputar a logica de Aristóteles um viés contraditório, reunindo em um só termo duas determinaçðes opostas, o acidental e o essencial. "Pelo contrário, traduzindo, antes, symbebēkóta kath' hautá pelos 'predicados per se', é possível conterir, em seguida, ao acidente, seu caráter modal próprio e aos outros tipos de predicados um estatuto kath' hauto." (pp. 105-107)

Contrabalançando os aspectos negativos do acidente (proximidacte do năo-ser, existência nominal, causas fortuitas e materiais) e em razão mesmo de seu objeto de pesquisa, emergem os aspectos positivos daquele atributo: trata-se de estabelecer o primado e năo de absolutizar o tipo

de ser que corresponde à primeira categoria, à ousia. Neste passo, o autor articula as análises nos planos lógico e emplrico: para fundar a oposiçăo entre o acidente e a substância é preciso "poder explicar năo sơ a potência do ser, mas tambêm o ser efetivo do symbebēkós, sem o que seremos constrangidos a conceber o real exclusivamente enquanto uma unidade ou uma pluralidade radical (...) Ora, na Metafísica, o caráter positivo de symbebēkós se deixa apreender a partir do reconhecimento de uma dualidade fundamental que se opera no seio do ser sensivel". (pp. 163-164)

Composto do necessário e do contingente, de maneira complementar e hierarquizada, "o ser do mundo sublunar é, primeiramente, enquanto substância e, em segundo lugar, acidente, mas nåo pode ser um sem igualmente ser o outro. A positividade do acidente manifesta-se aqui menos por oposiçâo que por relaçăo àquilo que the é ontologicamente anterior". (p. 164) Nesse quadro, "os seres do mundo sensívet não podern, tambêm, ser interpretados como unidades substanciais desprovidas de acidentes. A subståncia ê anterior ao acidente, mas, enquanto sensivel não pode existir sem eles. $O$ acidente pertence realmente à substância $\Theta$, por esse fato, se beneficia de um fundamento no ser". (p. 169)

Por caminhos diversos, Aubenque chega a conclusóes adjacentes. Ao examinar os textos relativos ao parentesco do acidente com o não ser e à sua existência nominal, ele os aproxima, contorme sugeståo de Brentano, das Categorias, onde se distinguem os predicados segundo o nome e segundo a definição, concluindo: "Ouando atribuo ao homem o predicado branco, eu the atribuo de fato o nome 'branco' e nåo a definição (lógos) do branco, ainda assim, tal atribuiçăo nominal torna-se possivel pela conjunçåo precisamente acidental do homem e da brancura (...) Por certo, o homem-branco existe como todo concreto. O que tem somente uma existência nominal, $\hat{\theta}$ o acidente isolado e seu pertencer ao sujeito". Assim, embora a definiçāo do branco jamais possa ser atribufda a um sujeito, "em certos casos" o nome pode, isto $\hat{\ell}$, "nos casos onde o acidente ad. vém eletivamente ao sujeito (eles poderiam nunca ter se encontrado)".

Se o homem-branco existe como todo concreto, aquilo " que tem uma existência apenas nominal ê o acidente isolado. Assim, o branco seria um năo ser se a linguagem năo o tirasse 'ern certos casos' de seu nada para atribuf-to hic et nunc, isto ê. em virtude de uma coincidência imprevisível e passageira - contingente, dirá Aristóteles - a tal homem em carne e osso. O acidente enquanto tal tem apenas a existéncia que the contere o discurso predicativo; cessada a predicaçăo. 0 acidente retorna ao nāo sere(tio).

Săo relaçōes extrinsecas, as dominantes nesse primeiro momento da interpretação de Aubenque. Logo, entretanto, essas análises, "que parecem empurrar o acidente para fora do ser", são contrabalançadas, através de outra reflexăo metalingüistica em Aristóteles. Examinando os significados conferidos ao verbo ser, nos Segundos analiticos, Aubenque conclui: "Aristóteles, para elucidar o sentido da atribuiçăo acidental recorre a um uso que poderiamos chamar de essen- 
cial do verbo ser, isto ê, aquele em que serve de copula numa proposiçāo analfica (...) se o homern nấo é o branco, resta que diremos, deste homem, que ele é branco, sendo portanto ao verbo ser que recorremos para exprimir a relaçāo acidental. Aristóteles reconhece, por essa análise, que o acidente năo se deixa lacilmente relegar para o dominio do não ser, pois que se exprime no vocabulánio do ser".

Ao lado dessa interpretação no plano "lingülstico". Aubenque apresenla indicaçőes sobre a concepçāo cosmoßgiça do acidente, "aquilo que não é nem sempre, nem o mais treqüente", isto e. "aquilo que nåo tem causa, a menos que se reconheça como causa a matéria que, ela própria, năo ê nada, pelo menos em ato". Pressente-se, entretanto, por al, "a possibilidade de uma reelaboraçăo cosmológica" do acidente, o qual, linalmente, é a regra no mundo sublunar: este "comporta a matéria e é, pois, submetido à contingência" ${ }^{\text {(161). }}$.

Mais voltado para a conjugaçâo entre ontologia e linguagem, Aubenque localiza as dificuldades resultantes do "privilégio exclusivo da esse̊ncia", isto é, "a exclusåo de toda uma parte do discurso (o discurso predicativo) e de todo um aspecto da realidade (a contingência, cuja predica. ção acidental é a manilestação no plano do discurso)". O resultado seria um mundo sem movimento e sem relação, com essências techadas sobre si mesmas, em cuja unidade nåo se poderia exercer o poder dissociativo e componente da palavra ${ }^{(162)}$.

Considerando os mesmos textos comentados por Aubenque, referentes à vizinhança entre acidente e năo ser, assim como sua existência nominal, B. Dumoulin os aproxima da antitese do ser e do não ser no Sofista, com a reserva de que Aristóteles estende ao acidente o que Platáo afirmara do falso. Desde que o mesmo Livro $E$ remete o ser como acidente e como falso ao "res. tante gênero do ser" (tó loipdn génos toú óntos, 1028a 1-2), opondo estas variedades deficientes ao ser em sentido estrito (kuriōs, 1027b 31), Dumoulin sugere que esta antitese evoque a oposiçăo entre o mesmo e o outro também estabelecida no Sofista (255c-e). parecendo-lhe que as coisas kath' hautá e prós héteron constituem a matriz da distinçăo aristotélica entre substância e acidente $e^{(163)}$.

O mesmo autor assinala a diferença entre a concepção do acidente no Livro $E$, considerado mais antigo, e no Livro $\Delta$, que se alasta da linha do Sofista. "Aristóteles critica Platăo por ter pensado, como Parmênides, que o ser era uno e contra Parmênides, que existia o não ser (...); de outra parte. Aristóteles acerta por completo a realidade do nâo ser, alargando consideravelmente seu campo (hâ o não ser segundo as categonas, o nâo ser como potência, o não ser como talso)."

Ampliaçăo esta que desloca o foco pelo qual o acidente é visto, subtraindo-o ao campo da pura negabividade: "o năo ser nåo é heterogêneo ao ser e não se deve transgredir o interdito parmenidiano (...) pois o năo ser ê uma forma enfraquecida e derivada do ser (...) Dessa perspectiva năo há mais como caracterizar o acidente como vizinho do năo ser". Mais ainda, o Livro $\Delta$ năo afirma sumariamente, como $E$, que nāo pode haver ciência do acidente: "ele denomina também acidente uma propriedade eterna da qual pode haver ciênciam(164). Trata-se dos "acidentes neces. sários".

Todas essas conclusőes que, vindas de planos diversos, terminam por convergir, nåo deixam de ser consistentes, também, com um ponto de vista já alcançado por Brentano, ao rastrear as mudanças registradas na teoria aristotéfica da definição. Cabe assinalar a grande diferença por ele marcada entre o Livro $Z$ da Metafísica, onde Aristóteles, restringindo a definiçăo à ousia, năo questiona a apreensăo conceitual de substâncias diferenciais, enquanto o Livro IV (12) da Meteo. rologia considera as dificuldades para alcançá-las, devendo ser substituldas pelas determinaçōes acidentais que as acompanham como propriedades e pela lunçăo (érgon) especffica exercida. Para Brentano, esta base da diferença estaria ligada a uma "evoluçāo do pensamento de Aristóteles, não só a respeito da maneira de definir, mas também, segundo parece, em relaçăo à cognoscibilidade das substâncias (...)".

O mesmo contexto lógico se reencontra em De partibus animalium, onde a definição năo se reporta às diferenças das substâncias, mas às propriedades ligadas a elas, como características, e que, no conjunto, oferecem um substituto às primeiras. Para Brentano, as mudanças na teoria da definiçăo devem-se aos estudos que produziram a obra acima citada, mas apresentam-se como prenúncio da futura transformaçăo, na doutrina de Metafisica $Z$ (1019a 11), onde ê dito que "se os acidentes fossem suprimidos, nada pareceria restar"(165).

Todas essas leituras chamam a atençăo para a tace constante do acidente, para seus vinculos com o ser e sua referência à ousia, esmaecendo os aspectos torturtos. V. Goldschmidt nos oferece um exemplo relevante nessa linha, ao lazer da tragédia uma sorte de hiperfilosofia, justamente por ser capaz de subjugar o acidente. Seus comentários mostram-se sobremaneira signiti-
161 Lo probieme de retre chez Aristote P. Aubenque. op. cit., D. 193, n. 4. 162 Lo probleme de rolre chez Alistoto P. Aubenque. op. cit., p. 143.

$163 \mathrm{Cl}$. Anayse gênétique de la MÁta physique d'Aristole. Parisimontreal Boltarminibelles Lettres, 1986, pp 144-5.

164 B. Dumoulin, op. cit. p. 187.

105 Aristóteles, F. Brentano. Barceiona Labor, 1983, p. 29. 
cativos, ıanto mais que ısolam os textos onde essa noçåo se encadeia à máxıma contıngèncıa.

Corno ponto de partida, Goldschmıdt ajusta o traço especflico da tragédia - suscitar medo e piedade - à estrutura da fábula. Esta, construlda segundo o universal, que é conhecivel, finda no maravilhoso, que parece efeito do acaso - do acidente, infinito e impenetrável ao conhecumento. (Met. E 1026b 3-4) Este último elemento diverge do primeiro: o acidente nāo é necessário, nem verossímil, tal como no célebre exemplo em que alguêm cava para plantar uma árvore e encontra um tesouro. (Met. $\Delta .30,1025$ a 14-19)

Entretanto, pouco a pouco esses termos văo se conciliando: o fortuito acaba atravessado pelo racional e as garras do saber terminam apreendendo o acidente. Uma vez explfcitos os termos em jogo - o necessáno e o verossímil; o acaso, a fortuna e o acidente - uma cadeia dedutiva se encarrega de ordenar as razôes atê a conclusāo. A tragédia imita a felicidade e a infelicidade $e$. mais exatamente, a boa ou má fortuna. O verossímil e necessáno é universal e conhecível; o acaso é indeterminado e impenetrável ao homem, tem o estatuto do ser por acidente, do qual nảo hâ conhecimento. Segue-se a essência da tragédia, que atinge o irrealizável por qualquer ciência: "dar um conhecimento do acaso, e isto pelos próprios instrumentos da ciência, a busca do universal. A tragédia representa a fortuna como efeito de um encadeamento inteiramente penetrável pela razăo (...) num sentido, a tragédia é mais filosótica que a propria filosofia: ela chega a tornar inteliglvel o ser por acidente". O acaso năo $e$ abolido, mas assumindo alcance universal, suscita medo e predade $e^{(t \in 6)}$.

Năo interessa, aqui, entrar no ménto desta construção, onde vânos deslizamentos dos tex. tos sảo produzidos analiticamente (por exemplo, não é a tortuna que, por sua figura trágica, tornase permeável ao raciocínio; racional - e isto até certo ponto - é a técnica capaz de projetá-la como ilusoria). Importa, antes, finalizar com um escrutínio que aprisiona a imagem - com sua carga sensivel e sua espantosa torça - no intelecto, levando ao limite as interpretaçठes que neutralizam as vicissitudes do acidente $e$ "amansam" o seu poder perturbador.

\section{Espaço e tempo imobilizados: a koinōnfa conservadora}

É tempo de reunir os aspectos que procurei ressaltar nos meandros da doutrina arıstotélica. Parti da ordem evolutıva que interliga äkos, kömē, pólis, na Polítıca. Meu primeiro cuidado toi considerar náo só as análıses de Anstóteles, mas todo um complexo de interpretaçōes afins, cujo foco diretor ê de ordem etimológica, localizando a casa enquanto espaço físico e social - sede e famnia - na origem dos agrupamentos humanos. Para a crfica desse aglomerado etimologico e do ideário poltitico que the ê congênito, acompanhei as análises de Benveniste, que destroem pela raiz essa grande montagem. Nesse percurso, pudemos distinguir como os vínculos entre o habital e o grupo humano, identihcados no oikos, oferecem um campo fértil para as representaçōes da "Tamilia célula social", embrăo oniginário que se desdobra até as fomaçōes complexas.

A crítica fundamental de Benveniste a Aristóteles é a de assumir o particular pelo universal, sıstematizando os processos por ele conhecidos, concernentes a formação dos "estados" gregos. Também a partır de Benveniste, configurou-se um ponto controvertido nas posiçð̄es anstotélicas sobre a linguagern, nas Categonas. Procedimentos paralelos aos da Politica al reaparecern: determınadas estruturas de uma língua particular são transpostas para a relaçăo predicativa e para os enunciados logıcos, pressupondo uma ontologia e almejando validade universal.

Devido a esses procedimentos generalizadores, procurei deslindar o modo como a casa, enquanto objeto artisoco. é tratada nas representaçōes lingüísticas. Para as análises de texto, fui inspirada no trabalho de $\mathrm{H}$. Weinrich, observando as diferenças e peculiaridades pertinentes ao sistema verbal grego. Verificamos que o uso dos presentes e perfeitos, nas exposiçðes da Fisica, não correspondem aos tempos cronoßogicos e aos processos a que såo explicitamente associados por Aristóteles, às continuidades e rupturas assumidas e ampliadas por vários comentadores.

Seres naturais ou produtos técnicos, todos sāo trazidos para o presente do comentário. apanhados na trama que fixa suas diferenças, mantendo-os nesse plano estático, para defini-los e classificátos. Princípios próprios à lingua unificam e ordenam a escrita do comentário, projetandose nos proprios elementos que exprime: pensamento e discurso encontram-se nessa lextura do presente, entranhados de constância e perenidade. Isto, porém, năo implica reconhecer em Aris. tóteles o estereótipo sobre a "linguagern reflexo da realidade". Muito pelo contrário, todo um trabaIho inventivo cabe à palavra na emerge̊ncia das questōes e em sua apreensảo conceitual.

A leitura da Física, norteada pela categona lingüística do comentáno, permitiu observar co-

$166 \mathrm{Cl} . \mathrm{V}$. Goldsctumidi, V. Jemps phrsi. que of temes iragigue chez Anstote. Paris, Vin, 1982, Op. 263.265. mo a tinguagem incorpora-se à composição cientffica de um sistema integrado. coeso, subsistente. Os tempos gramaticais, operando no plano da sintaxe e da semántica, tecern a rede de repre- 
sentaçőes cientfficas: o "sistema dos presentes" circunscreve a problemática e ilumina o modo de concebe-la num todo constante, integrado, continuo. A "co-autoria" de linguagem e pensamento encaixando-se num present tense que deglute o que passes with time - reforça o ponto de vista fixo, centro do horizonte imperturbado da contemplação aristotélica.

A presença do ser trazido pela palavra năo pode evitar a passagem por seu locus classi. cus, Heidegger. Tomando-o por referência, foi possivel captar a linguagem funcionando como fonte doadora de significados, de principio unificador dos conceitos e, mesmo, de paradigma metodolbgico, e năo apenas como instrumento posto a serviço do intelecto a fim de expressar a "rea. lidade" por ele apreendida.

Isto nos conduziu da Física à Metafísica e, de novo, ao problema dos verbos e das açōes. dos presentes e perfeitos gramaticais, identificados à cronologia e a pressupostos ontologicos. O foco da atenção dirigiu-se, desta vez, para a práxis. No âmago de toda esta discussăo delineiase com intensidade um quadro unificador e harmonioso do agir humano. No caso da poiēsis, temos ainda o tempo medindo o movimento que se esgota, que se nega ao completar-se. Na práxis, o tempo é do agora, e se ainda mede alguma coisa, nåo é o movimento, mas o repouso.

Considerei, em seguida, o problema da poiésis e da práxis, conjunta e concretamente, na Poética. Sāo al apresentadas técnicas de produção artística que, partindo do efetivo, dele se desprendem para compor a imagem que mantêm ao mesmo tempo a fidelidade da cópia - eikōn, nem eídőlon. nem phantásma - e o teor unitáno, integrado, constante, do universal. Os processos inventivos, próprios à obra de arte, dependem das ilusőes óticas, que tiram partido do fenômeno tanto no que aparece, quanto no que parece ao público.

De novo, o que há de mais permanente e contínuo no mundo social - o costume, o hábito, segunda natureza - ressurge corno chave que permite selecionar os elementos invariáveis e coerentes, unificando suas significaçőes. Práxis e poiēsis nutrem-se, na Poética, da vida transfigurada no que existe de mais estável, de mais pacificador, subjugando o elêmero, domesticando o enigmático, o aterrador. O ponto fixo que, nesse âmbito tranqüilizado, determina sua escala de medida, e controla sua aleriçăo, ê o próprio poeta.

Estendi um pouco o exame para o campo dialético e retórico, para as posiçōes de Aristóteles sobre as divergências entre a linguagem literária e técnica. Novamente, o costumeiro se afirma, dominando o inabitual, traço este que não apenas aparece no conteúdo doutrinário, mas res. salta no plano da expressăo, com pensamento e linguagem sempre se entretecendo.

Por essas largas vias conduzindo ao equilibrio e ao repouso, - no limite, ao imovel e eterno - chegamos a um terreno onde as coisas arriscam descarrilhar, o acidente. Também af, toda uma tradiçăo de leitura ou simplesmente o afasta, ligando-o ao fortuito, ao aleatório, ou acentua o lado que o prende ao necessário, ao essencial.

Esse percurso evidencia a amplitude dos significados altamente estabilizadores, embutidos nas concepçőes aristotélicas de poiésis e práxis, a enome tensão visando atenuar o movimento. reter o tempo. Vasto horizonte que nos permite reunir um objeto técnico (a força produtiva nele investida, assim como seus resultados, a poiēsis realizada na casa-edifficio) e as açōes humanas (a atividade imanente e a teleologia auto-reprodutora unidas na práxis, onde se inclui a casa-farnflia). Mediante critérios apreendidos na própria construçăo dos textos, oikia, sede ffsica e grupo social, aparece como sintese de espaço e tempo imobilizados no repouso da obra artística ou na constância da prática humana: nela, a solidez vai fundo, é parte da firmeza própria à vida onde se talha a hierarquia entre o perene e o efêrnero, corte cujo ideal é a enérgeia akinēsias.

Neste amplo e tranquilto panorama - quase etéreo - onde se desenham os objetos produzidos pelo homem e a própria ação humana, ensejando superpor o espaço dos primeiros e a temporalidade da ühtima, podemos melhor apreciar os caminhos de Aristóteles na Polnica, a coligir as informaçôes sobre a "história dos atos humanos" e ao ordená-las numa seqüência evolutiva.

Voltemos ao ponto de partida: o tivro I da Politica apresenta a $\rho$ blis como um todo, concebido como unidade natural, gerado pelo desdobramento imanente das comunidades primitivas, a casa e a aldeia. A cidade constitui o " $\mathrm{lim}$ " desse processo: "aquilo que cada coisa é, acabado seu crescimento, a isto dizemos ser a natureza de cada coisa". Este conceito de phýsis pede cuidado ${ }^{(167)}$. A concepção da polis enquanto anterior se inscreve em princlipios de ordem metalfsica, coincidindo corn o sentido fundamental da palavra, isto é, "segundo a natureza e a essência". Em outros termos, săo ditas anteriores "todas as coisas que podem existir independentemente de outras coisas, enquanto as outras coisas năo podem existir sem elas"(168).

Embora visando algo diferente, o comentário de Aubenque a esse respeito interessa à Pol. tica justamente por acentuar o prisma teleológico: "o tempo da natureza e da esséncia será o inverso do tempo da gênese: 'o posterior segundo a geraçâo é o anterior segundo a natureza ou
$167 \mathrm{Ct}$ Polfica, 1, 12520 33.35. Para um paralolo com outras obras de Aristoteles, especialmente a Etica a Nicomaco, ct, K. won Fritz e E. Kapo -Atistotie's political phylosophy and the concept of nature ${ }^{\circ}$ in $\mathrm{J}$. Barnes. M. Schofiete, A. Sorabli, Articles on Atistotie, 2 Ethics and politics. London. Duckworth. 1977.

$168 \mathrm{Cl}$, Metaflsica $\Delta, 1019$ a 2-5. 
$169 \mathrm{Cl}$. Pierto Aubenque, ce probisme te rotre chet Aristolo. Op. cit., D. 49

170 Polnca, $1252035-6$.

171 Polika, 1, 1253 a 1.

172 Poincs, 1. 1253 a 3.5

173 Fol esteo tema exclor ado em meu IA colendo snato gobre John Locke a propriodade como concelto antrocologico fungarmontal.

174 Poinica, 1. 1253010

175 Para a violencia dessa bgura. ct. J. Dumartier, Les images dans it pod Sir d'Éschile. Paris, Belles Lettros. 1975.

176 Aristoteles mesmo absim o laz. CI. Elica a Aredruco, 11280 16, 1175a 19.

i7f Poinca, 12530 10.13. Em sua edr. Gao (Paris, 1982) Thicol tembie para Nowman $\{0 \times$ tord, 18a7-1902). 03. clarecendo: Aristotolos tem o sonti. mento que o adpebro gamie nao descreve a natuteza da alche ob marido sobie sua multher táo ciata monte quanto despotike descreve a dominica potestas. ainda segundo a essência', o que quer dizer que o perteito é anterior ao imperfeito na ordem da essência e da natureza, mas the é posterior na ordem da geraçăo, principio que é enunciađo e aplicado sobreludo onde predomina a consideraçăo da causa linal, isto ê, nas obras biológr-

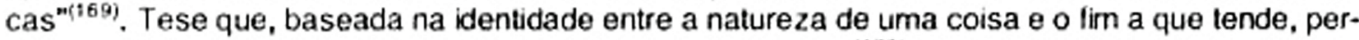
mite reunir, num mesmo âmbito, "o homem, o cavalo, a casa" ${ }^{\prime 170)}$. No interior desse perlmetro lotal e uno. đá-se a identidade entre a natureza, o homem, a vida clvica.

Taıs exemplos prenunciam o equacionamento entre vida bioßgica e social, desenvolvido nas célebres passagens seguintes, alinhadas pela consideração da causa final: "aquilo para o que algo existe, seu fim, é o melhor 'in'!

A pólis, imanente à natureza e perteita, por isto mesmo excelente, corresponde o homem que é, também por natureza, um "animal politico". Nessa classificação, todo aquele que é "acivico", por nalureza e não por ventura, é excluldo de sua espécie. Escapando à norma do princlpı definidor, esse individuo fica necessariamente fora da escala humana: à excelência predicada para a cidade e o cidadăo completos será contraposta ou a inferioridade deleituosa, aquém destes modelos, ou a superioridade excessiva, que o ultrapassa ${ }^{(172)}$.

A fortuna dessa taxinomia foi nolável pelos tempos alora. Na época moderna, a classificaçăo entre os incluídos na espécie humana e os dela expulsos - postos entre os animais de carga ou de rapina - constitui a logica subjacente ao poderoso mundo dos proprietários-livres-iguais, naturalizando a exploraçăo do trabalho alheio e fundando um novo direito e policia repressores. A filosofia aristolêlica transfigurou-se neste âmago do ideário liberal, legitimando a dominação da burguesia já solidamente estabelecida. O segundo tratado sobre o governo amplia, atê as últimas conseqüências, as premissas e virtualidades contidas no pensamento antigo ${ }^{(173)}$.

Relornemos à oikia tal como aparece na Polnica. Se as "menores" partes constitutivas des. se todo săo presididas por uma teleologia que as torna irredutlveis umas às outras - reproduçāo da espécie, subsistência e segurança - o espaço e a sociabilidade as colhem num todo unitário e infrangivel. Como vimos, a tonga história das palavras que organizam esse lexto aponta para a possibilidade mesma dessa torte coesão interna. Desde seus mais antigos empregos o verbo oikéō denola um lugar de residéncia e um modo de vida, năo apenas suportes, mas dimensð̋es constitutivas de tipos humanos e formas de sociabilidade.

O vínculo originário entre espaço demarcado e vida social é o pressuposto iniludlvel que nos dâ o primeiro acesso às significaçōes liberadas pela imagem que Aristóteles empresta de Hesiodo: "Em prımeiro lugar uma casa, uma mulher e um boi", vindo este último em substituiçăo ao escravo, instrumento de trabalho inacessivet ao agricultor mais pobre. Demoremo-nos um pouco nesta montagem primordial da oikia.

Aristóteles observa que a "união đo homem e da mulher năo tem nome"(174). Esta frase encontra-se na oikonomia, concemente à regulamentaçåo da casa, dividida em suas partes primeiras e menores: marido e mulher, pai e filhos, senhores e escravos. Esses elementos uniticam-se num todo soberano (a polis é kuriōtatē em relaçāo a todas as outras koinōniai), ordenando-se para o bem supremo, segundo uma hierarquia naluralmente constitulda. Em Arisıóteles, a natureza nunca é mesquinha: pelo contráno, é abundante em finalidades conexas a formas de domínio especializadas para cada lunção. Nesta natureza copiosa, onde a polis se organiza para a perfeição, a koinōnia é primordialmente archē, năo so princípio de constituiçăo mas também de mando, aspecto muito pouco lembrado nas leituras de Aristóteles.

Os instrumentos dominados, nessa teleologia, diferenciam-se levemente, se olharmos as coisas bem de perto. Com certeza, a mulher nāo é idêntica ao escravo, ressalva imprescindfvel para constituir os pares essenciais a koinonía primitiva, instauradores de procriação e trabalho. Mas é significativo que, entre as múltıplas possibilidades oferecidas pela lingua grega para designar as relaçōes sexuais e de parentesco. Aristóteles tenha escolhido justarnente uma imagem carregada de máxima sujeiçáo, súzeuxis, designativa de animais atrelados sob o mesmo jugo ${ }^{(175)}$. $\dot{E}$ certo que a expressão pode ser usada em oulros sentidos figurados ${ }^{(176)}$. Entretanto, a estrutura do presente texto não poderia ser mais determinante dessa forte nota autocrática. As três ordens de relaçóes na koinonia anstotética caracterizam-se como: despotikë, gamikë, teknopoiëlikë ${ }^{-1177)}$, sobressaındo o poder absoluto do chele da casa nas relaçôes de trabalho e parentesco. O primeiro é imperante sobre todas as outras instâncias e. por paradoxal que pareça, o estatuto da mulher ıgualizada ao escravo, nesse plano, decorre de sua própna diterenciaçăo, acoplada a força expansıva do poder doméstico rumo ao político, até seu extremo, o domínı imperial.

No interior da casa grega, a mulher se distingue do escravo: ela procria e ele trabalha, ela 
participa de certas faculdades humanas da qual ele é privado. Suas finalidades na conservação e funcionamento do oikos divergem, mas năo se pode esquecer que esse todo orgânico é unitário. concentrando o poder num único feixe de irradiaçăo cuja fonte é também natural. $\mathrm{O}$ segundo argurnento apresentado por Aristóteles ilumina o sentido desta primeira caracterizaçāo: entre bárbaros, a têmea e o servo se equivalem. Mas isto se deve a um mesmo e decisivo fundamento: o poder, al, năo se determina por natureza; a koinōnia, neste caso, é entre escravo e escravo. Nota-se claramente, juntando os dois argumentos: a posiçāo natural da mulher, na casa grega, determinase basicamente pelo poder ao qual está submetida. Sua diferença especllica aparece pela absoluta sujeiçăo genérica a que está presa à casa como um todo.

Essa preeminéncia do poder despótico se transfere, em essência, para a justificativa do domínio exercido sobre estrangeiros. Donde a citação do poeta: "ê verossímil que os gregos govemem os bárbaros, pois bárbaro e escravo săo o mesmo por natureza"(178). A continuidade das linhas de poder, da casa ao império, toma, no minimo, problemática a partiçăo que Aristóteles estabelece entre dominio privado e público, diferente este, porque exercido "entre iguais". Năo ê so entre helenos e bárbaros que o poder se legitima, mas também sobre as colónias, sublevadas com denúncias de escravizaçăo e reprimidas com a clara consciência da força e da astúcia imprescindiveis para mantê-las.

Ao citar os versos de Heslodo, é justo a polissemia da casa como espaço habitado e como núcleo de poder que Aristóteles pōe em relevo, nesse primeiro estágio dos agrupamentos humanos, assimilando o social a seu lugar. O segundo degrau na progressāo integradora de natureza e cultura, base das reflexठes de Aristóteles sobre a polnica, torna mais claro o movimento imanente que leva da casa à aldeia, carregando consigo toda a carga de dominação encerrada na primeira. Ampliam-se as relações de dependência, abrangendo não apenas laços consangüineos, mas afins (em Aristóteles lala-se de "irmăos de leite", homogálaktes); aumenta a produçāo, cresce a unidade local, introduzindo-se um terceiro vínculo, a vizinhança, congregando maior contingente humano. O movimento expansivo transcorre em partes determinadas do espaço, balizadas por circunscriçð̋es cada vez mais extensas.

O próprio vocabulário utilizado por Aristóteles é bastante significativo desse vínculo entre espaços fisico e social. "Muito tortemente, segundo a natureza, a aldeia parece ser uma extensão da casa." Acompanho, aqui, a soluçăo de Tricot para oikía e apoikía, termos que traduzidos literalmente nos diriam que a aldeia é uma "colônia" da casa ${ }^{(179)}$. Será sempre necessária, entretanto, a ressalva de que o nosso vocabulário năo faz presente, como seria desejável, o espectro semântico das palavras gregas oikia e apoikia, que sintetizam implicaçōes simultaneamente espaciais e societárias. A trase acima é interessante, em especial, porque aponta o quanto "a ligaçăo entre oikia e apoikía é sensivel aos gregos ${ }^{(180)}$, bem se justificando a traduçăo de Tricot: ela acentua o prolongamento colonial implicado na aldeia, conjunto de familias, de modo tal que a primeira constitui uma ampliaçāo destas últimas. Desse modo, a passagem da famflia à aldeia, so poderia mesmo ser "fortemente natural": num movimento imanente, săo mantidos no segundo estágio os elementos originários do anterior, inclusive relaçōes de poder.

Sabe-se que o campo semåntico de oikéō, nos séculos $V$ e IV, indica significados gerais em tomo de habitar, nâo chegando a envolver denotaçőes especificas sobre colonização como projeto organizado. Aproxima-se, porém, de oikizo e seus compostos, o qual, no período clássico, época em que se consolidaram as migraçōes planejadas, torna-se um verbo que "exprime diversos movimentos coloniais, sem que seja obliterado seu valor de base, a residência". (pp. 81 e 92. esp.)

Idêntica afirmaçāo pode ser feita sobre os compostos desse grupo, apoikéō e apoikizō. que embora em sua formaçăo carreguem traços de afastamento (com apó), implicam também sentidos estáticos, visando agrupamentos "situados a certa distância". (p.115) É nesse campo semântico que ressaltam os valores de apoikia, compreendendo tanto a organizaçăo social quanto a estrutura física de seu estabelecimento. Confirma-se o prisma de centidos já apontados para oikia: uma apoikía é um deslocamento de colonos (ápoikoi) que imigram para se estabelecer em outra residência; mas é também o têrmino dessa expediçăo - a colónia de povoamento - ligada à metrópole po: laços que justificam o "parentesco" (syngéneia).

Esta nova instalaçâo constitui uma "colónia de...", marcando liames de ongem e dependên. cia em relaçăo à cidade hegemónica, sede do oikos, contorme nota Cazevitz (pp. 128-9). Segundo este autor, porém, "enquanto a syngéneia estabelece uma relaçāo 'horizontal" (ligaçáo de parentesco entre povos da mesma etnia, Jônios entre si, Dóncos entre si), ápoikoi nota uma relaçáo 'vertical' de um povo ou de uma cidade para com outro povo e outra cridade, relaçāo de origem.
178 Polltica, I, 125108.

179 Polntica, I, 1252b 17: he nome oi. klas apoikta. Ct. ed. Tricot, nota ad. loc.

$180 \mathrm{Cl}, \mathrm{M}$. Cazevits, Lo vocabulare de la colonization on grec ancien. Paris. Klincesiect 1965, p. 134. As intor macbes, nos parAgralos seguintes. sobte o assunto, reportam-se a este trabatho. Os números entue parten. coses rototem- 08 a paginas dc 
181 Le territoire de i'homme, Ellas Ca. netti. Paris, Albin Michel, 1987. tornada também, pelo século VI, relação de dependência" (p. 119). Caberia indagar se a figura poInica do parentesco nāo transpōe, justamente, a carga dominadora contida nos laços consangülneos e afins, implicaçăo que nāo é alheia a várias passagens de Tucídides, por exemplo. Se assim for, os vínculos do génos e da oikia, antes de se distinguirem, se sobrepōem e se reforçam.

Toda essa gama de significados é mantida na imagem da Polnica: o privilégio das conotaçర̄es espacializađas, a comunidade primitiva ampliando-se numa aglomeração dela resultante, de modo tal que o núcleo de consangüinidade e cooperação produtiva se desdobram num outro espaço circunscrito, abrangendo afinidade, riqueza, vizinhança. Em suma, a apoikía implica em um deslocamento tanto físico quanto social, a partir de uma regiáo-sede, mantendo-se, por extensáo e de modo ampliado, os componentes da primeira em um novo e próprio lugar, inclusive o peso do poder.

É bem esse o conjunto de significações sintetizado no texto de Aristóteles, hē körnë oikias apoikia: movimento, espaço e vida social contínuos, conservando-se, no interior das mudanças, a comunidade primitiva desenvolvida.

Năo é preciso ir muito longe das cie̊ncias humanas para reconhecermos o imenso e protundo conservadorismo que, sucessiva e reforçadamente, fomos constatando no leque de textos aristotélicos. Influência tão ditundida por outras instâncias às quais esta filosofia ligou-se historicamente - como a Igreja e a Universidade - que năo raro passa desapercebida pelos próprios epigonos, alguns deles repetidores de leituras Iragmentárias, cujos contextos intelectuais originários foram perdidos de vista.

Poucos, no mundo modemo, experimentam como Elias Canetti um "sentimento esmagador de exfiro, de estranhamento, ao ler Aristóteles. (...) Outra atmosfera, outro clima, ordem de valores totalmente diversos. Experimenta-se um verdadeiro arrepio de pesadelo, ao considerar a parte 'suprimida' de sua doutrina, que sustenta, entretanto, aquela que ainda hoje é apreciada, e ao medir o quanto nossa moral ainda é tributária dos preceitos de Arisłóteles"

Como se năo bastassem as mirlades de escaninhos onde a imagem global do mundo foi encerrada na filosofia de Aristóteles, a cultura moderna sobrecarregou seu legado com maiores entraves. Por exemplo, o vinculo intimo entre tempo e lugar, presidindo a gênese e desenvolvi. mento das koinōniai em Aristóleles - concepçáo esta por si mesma já conservadora e autoritária - teve seus efeitos muitas vezes potenciados pela própria representaçăo de espaço elaborada na Modernidade. 